\title{
Sustainable mobility and economic sustainability: the case of the new trolleybus line in Genoa
}

Ilaria Delponte*, Paolo Rosasco**

keywords: Urban mobility, trolleybus line, cost-benefit analysis

\begin{abstract}
With over 3.5 billion people currently residing in major cities around the world, the issue of urban mobility is a current issue and is particularly important in European countries where over $75 \%$ of the population is concentrated in urban areas. Even today, many of the daily journeys depend on cars and other private motorized vehicles, with a strong impact in terms of air pollution, noise and climate change as in the European Union transport is responsible for a quarter of greenhouse gas emissions. Reducing private transport and making urban transport systems greener and more efficient therefore has important benefits: for the health, climate and prosperity of cities. New models of transport and urban accessibility, increasingly oriented towards environmental sustainability, must therefore be adopted; the choice of the transport solution must be made in relation to not only technical but also economic, social and environmental feasibility. Taking a cue from the Call issued in 2018 by the Ministry of Infrastructure and Transport for the selection of urban mobility proposals that can ac-
\end{abstract}

cess the economic resources intended for the enhancement and implementation of rapid mass transport systems provided for by Law no. 232/2016, this contribution deals with the evaluation of three transport proposals hypothesized for the connection between the city center of Genoa (Brignole station) and the district of Prato, along the Bisagno Valley, developed according to the indications contained in the Urban Mobility Plan of the Municipality.

In particular, a Cost-Benefit Analysis (CBA) is developed according to the indications given in the Notice and in the Guidelines of the Ministry of Infrastructure and Transport for the evaluation of investments in public works. The objective is to verify the applicability of the CBA tool for assessing the economic and financial sustainability of the solutions analyzed - also in relation to the indications given in the legislation, the transport scenarios configured and the reliability of the results obtained, for the the choice of the transport solution to be adopted.

\section{INTRODUCTION}

In a moment of growing concern about global warming and other environmental problems, an increased use of local public transports is often proposed as an essential contribution to a complex solution (Holmgren, 2013; Mugion et al., 2018). 
Although, for a long time, this topic has been perceived as a niche one, today we are all universally interested in an efficient and reliable mobility service, thanks to a more acute perception of the social and cultural significance that collective transport holds in the sphere of interests of the citizen.

It is interesting to ask the motivation of this paradigm shift (Banister, 2008; McLeod et al., 2017).

Contemporary cities, in Italy more than in any other situations, are the result of multiple stratifications that have taken place over centuries of history that have transformed the lively medieval villages into chaotic, and often disordered, metropolitan cities. Constantly changing, they transformed themselves according to the economic and social evolution. However, each of them followed extremely variable and diversified processes and dynamics, based on the singularities of the context (Egmond et al., 2003; Pflieger et al., 2009).

As known, the process of industrialization and reconstruction, which began after the war, has led to radical changes in the urban and productive structure of many Western cities. These changes that occurred quickly, often without adequate planning, have given rise to serious problems regarding the liveability and healthiness of urban areas. In recent decades, awareness of these issues has led to the implementation of policies to adapt the large European cities (Costa, 1996; Gwilliam, 2002) for better environmental performance.

The major changes in the urban layout are accompanied by an adaptation of the infrastructural apparatus, which is necessary so that the movements can take place quickly, safely and efficiently, on pain of the decline of the city itself and abandonment by its citizens.

What emerges, in fact, is that one of the crucial factors among cities that want to compete internationally is the efficiency of the public transport system (Disney, 1998, Roy et Yvrande-Billon, 2007, Hayduk, 2018). The service organized for the community, based on criteria of efficiency, reliability and inclusiveness, guarantees fairness in the relationship with citizens and contributes to a positive marketing promotion of the city. In 2015, the Institute for Social Research analyzed those good practices that contribute to improving the accessibility of public transport, to strengthen the EU's promotion of the integration of social inclusion issues in public transport policies. These approaches also aim at protecting the environment, trying to move users towards collective transport and promoting less polluting traction systems. The planning of sustainable systems and infrastructures makes cities attractive, promotes investments and the creation of businesses and jobs (Malecki et. Veldhoen, 1993; Delponte, 2014; Gibbons et al., 2019). From this picture it is clear how, for the Local Public Transport (LPT), a relaunch is envisaged in every aspect: economic, social and environmental.

As a result of this renewed interest, the challenge that has been launched is aimed at the ability of public authorities to find innovative solutions for transport services, activating and coordinating different operators on various levels to provide integrated and flexible transport services capable of reaching different destinations and to allow several categories of users to organize both short and long trips.

A study presented at the European House-Ambrosetti 2017 estimates that Italian metropolitan cities, aligning collective transport with European best practices "could generate an economic benefit of 10/12 billion of euros per year, including decongestion, time savings, accidents and atmospheric, acoustic and climatic pollution "(European House-Ambrosetti, 2017).

Precisely in relation to sustainable mobility, this contribution deals with the assessment of the economic feasibility of the project of a new trolleybus line in Genoa.

The work is structured as follows: section 2 briefly outlines the urban context within the city of Genoa the Bisagno Valley - (Val Bisagno) - taken as a reference in the study and the planning tools provided by the Municipal Administration to support mobility projects; section 3 describes three possible transport solutions to be adopted for public transport along the Val Bisagno and the related technical characteristics.

Sections 4 and 5 are dedicated to the financial and economic evaluation of the three transport solutions through the application of the Cost-Benefit Analysis technique with the related results reported in section 6.

Section 7 reports the sensitivity analysis of the input variables of the CBA model and the application of the Monte Carlo analysis for the probabilistic assessment of the results obtained. In the conclusions of section 8 , some critical reflections are reported; they are focused on the applicability of the technique for evaluating the design proposals for the new Val Bisagno trolleybus line, and on the process and methods used, which may be diffused and replicable in other similar cases.

\section{URBAN MOBILITY AN PLANNING TOOLS: THE GENOA CASE STUDY}

In order to frame the sustainable mobility interventions that have recently been planned in Genoa, a territorial and regulatory contextualization is necessary which, on the one hand, shows the reasons of the solutions adopted by the Ligurian capital and, on the other, allows readers to better understand how the "Superba" it is inserted as a test-bed within the recent legislative evolutions.

The peculiarity of this territory is first of all due to the fact that, unlike the large Italian and European cities, most of the resident population of the entire metropolitan area is concentrated in the capital: about $69 \%$ of the population resides within the borders of the Municipality of Genoa. It is a densely populated area, but only $30 \%$ anthropized: the rest of the municipal area is not accessible and is covered by uncultivated vegetation and is characterized by steep slopes. At the same time, the remaining ex-provincial population (so called, as by Law no. 56/2014 suppresses the Province where the Metropolitan City has been established, a new type of administrative body with greater powers 
than the previous large area government).

Evident is the morphological uniqueness that characterizes the city: its complex road structure, resulting from unjustified settlement choices, does not always reveal the potential it contains. And it is precisely this complexity that forces the urban mobility system to be extremely diversified. In order to meet passenger demand, the LPT service has buses, trolley buses, vertical and horizontal lifts, funiculars, racks, underground and marine transport.

The roads and infrastructures in the area are often small and inadequate, the carriageways are almost always one-lane in each direction and often the one-way streets lead the user to take a different route between the two ways when traveling. The complexity is increased by the fact that the roads climb towards the hills and the lack of space does not allow ample room for maneuver.

These factors significantly affect the way people move around the city. In fact, the data reported on the Municipality of Genoa show how the rate of use of LPT by residents is $32 \%$, a rather high percentage for the Italian scenario and also the share of non-motorized internal movements, i.e. on foot or by bike, is $23.8 \%$, an extremely high score for a city that is not exactly flat, third only after Turin $(32 \%)$ and Bologna $(28.2 \%)$ in which the contribution is made by bicycles, not by pedestrians.

The Genoese reality is unique also in relation to the demographic structure and the dynamics of transformation; the resident population is aging and contracting significantly.

The old-age index, i.e. the ratio between the population aged over 64 and those under 15 , is higher (2.4) than the weighted average of the 14 Italian Metropolitan Cities (equal to 1.5) (Municipality of Genoa, 2019). The population trend shows a marked decline: from 1981 to today the residents have dropped by about 200 thousand units, in contrast to what is observed in the major Italian cities. This particularity brings with it inevitable considerations and differences that are reflected in the Genoese scenario of mobility and social relations that are intrinsically present in the urban environment.

With regard to the vehicle fleet, the data provided by Italian Automobile Club show that the number of cars circulating in the Metropolitan City of Genoa amounted to 421,000 in 2017 (year of investigation for the Mobility Plan, as specified below), slightly down on in the past, but in the capital alone, however, 270 thousand circulate, equal to about $65 \%$ of the total.

However, an emblematic figure for Genoa is the density of cars (car fleet per 1,000 inhabitants) of 492.94, the lowest compared to other metropolitan cities. Speaking in terms of absolute value, Genoa's car fleet is rather small; lower values are present in Cagliari, Messina and Reggio Calabria (ISPRA, 2017). However, the extremely controversial picture of the trends, that are impacting transport on a global scale, fits into this well-marked representation of the current Genoese mobility situation.

The introduction of so-called "disruptive" technologies is leading to major changes in the world of transport, according to a perspective of greater efficiency and safety.

These factors place metropolitan realities in front of a major challenge, namely identifying the ways in which to manage and take advantage of these innovative technologies, in order to solve the major problems that afflict these contexts (pollution and congestion, considered primarily among negative externalities). Digital platforms from which to access and pay for a range of on-demand transport services are candidates for this task; through this unified innovative system (commonly called MAAS, Mobility As A Service) it is possible to offer individuals simultaneous access to the

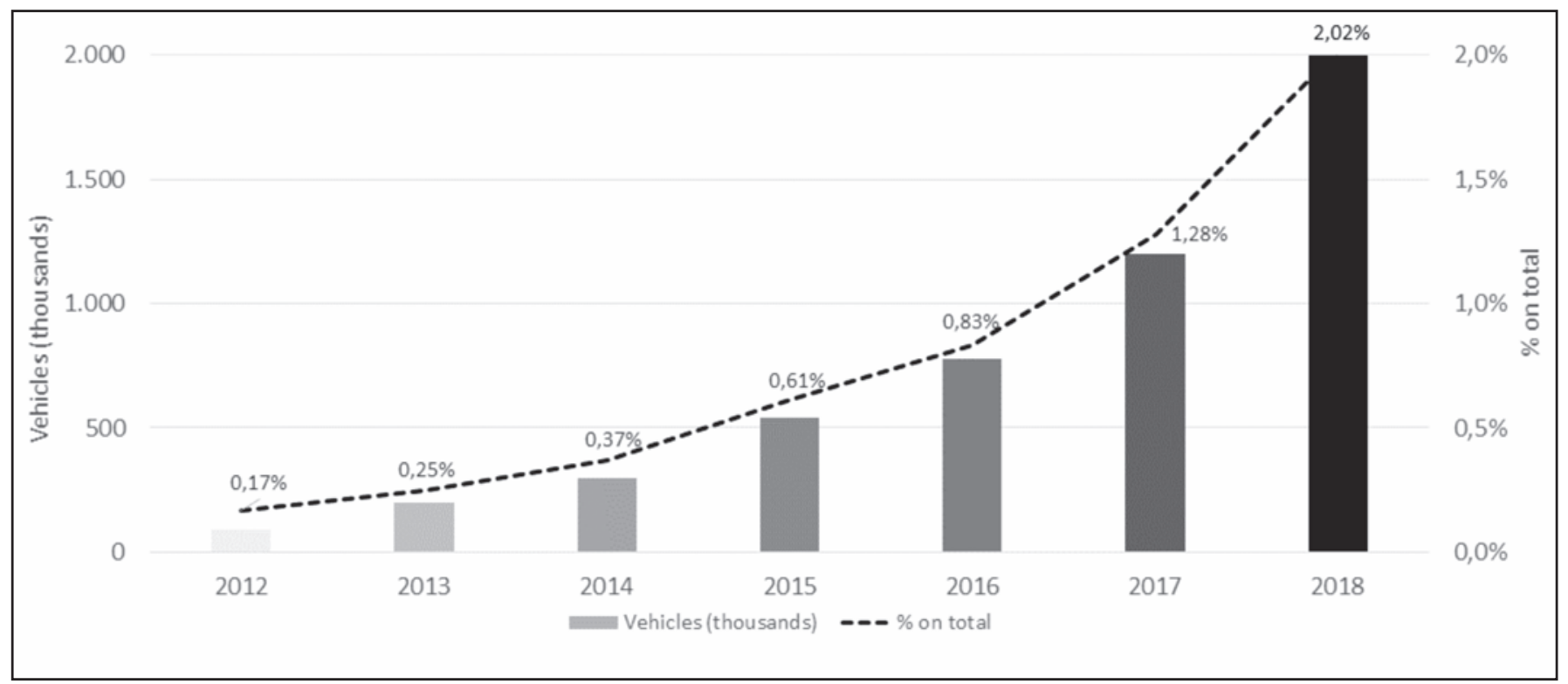

Figure 1 - Global sales of electric cars and percentages of total cars sold. 
different transport services: from trams and buses to taxis and bike sharing (Standing et al., 2019).

Technological innovation is also fostering the digital paradigm in the mobility sector; in fact, vehicles able to exchange information with other devices in the proximity are starting to be present on the market (Gal-Tzur et al., 2014; Harris et al., 2015; Schwanen, 2015).

This technology is already widely developed and will support the progressive phases that should lead to the autonomous vehicle, as a mass product.

Within changes of this magnitude, electric traction is one of the most promising technologies, capable of improving the quality of life in metropolitan contexts, reducing emissions - that alter the climate - and dependence on fossil fuels.

In the last five years, the electricity sector has seen a significant expansion in demand (Figure 1 - Energy and Strategy Group, 2018).

In the last five years, the electricity sector has seen a significant expansion in demand (Figure 1 - Energy and Strategy Group, 2018).

The paradigm shift in Italy is not so timely for now: at the close of 2018, with 14,000 electric cars in use, the peninsula ranks among the tail - lights of Europe, even if the technology providers are gearing up to respond to the demand and the tendency to promote electric mobility in urban areas, sharing this target with the National Regulator who have also provided financing plans. For example, the ministerial initiatives of the National Infrastructural Plan for the Recharging of Electricity-Powered Vehicles (PNire) (Ministry of Infrastructure and Transport, 2012) - and of the Integrated National Plan for Energy and Climate 2030 (PNIEC) (Ministry of Economic Development, 2020) can be cited. The transition to electricity in the field of public transport is already partially underway.

Most of the large metropolitan realities in fact need to modernize the fleet of LPT vehicles, and to choose vehicles that are increasingly green: the conversion to electricity is therefore part of the ordinary investment plans of companies. Furthermore, in accordance with the European Directive 2014/94 on alternative fuels, the coordinated action at national level involves in addition to electricity, other fuels such as liquefied and compressed natural gas and hydrogen. If the shared goal is to mitigate the effects of greenhouse gases and more, the question is how to ensure that this cultural change takes place with the inclusion of everyone and contributes to an increased competitiveness of the transport system and of the country. Aware of the current state of Italian urban contexts, of which Genoa is a symbol, in August 2017 the Ministry of Infrastructure and Transport (MIT) introduced a new planning tool dedicated to the 14 Metropolitan Cities, the Urban Sustainable Mobility Plan (PUMS) (Ministero Infrastrutture e Trasporti, 2017) with the central objective of electrification of Rapid Mass Transport (RTM). In particular, three categories of works are eligible for funding: Metropolitan Railway Systems, Metropolitan Railways and Tramways, or in any case infrastructural interventions that create a zero-emission RTM. The decree starts from an assumption: the travel speed of the Italian LPT is about half that of the large European metropolitan areas. The Italian anomaly compared to other European countries is the marked undersizing of the rail mobility network (trains, trams, subways): in Italy the number stops at $3.8 \mathrm{~km}$ per million inhabitants of the underground network, half of that of Germany and a third of Spain.

Therefore, according to the MIT, it is necessary to invest in electrical infrastructures that have such an impact on the city as to considerably reduce gas pollution, to allow an increasingly decisive modal shift towards collective transport and to justify heavy costs in the long-medium term.

The main target areas of this initiative are, as mentioned, the metropolitan cities.

Starting from an accurate knowledge of the territorial contest, the PUMS of the Metropolitan City of Genoa ${ }^{1}$ articulates the proposal of 4 "core routes" (mainly on a dedicated lane) that unfold on the municipal area, intercepting the most important directions of city mobility. Then, leveraging on "mass" transport, intercepting the greatest number of users on the entire area concerned (not only on a particular route), and on speed and punctuality by ensuring the protected lane along almost the entire route, prioritizing LPT over private transport. At this point, however, the technological choice of "how" and "with what" to equip the axes arises: Genoa attempts, according to the PUMS objectives and the consequent funding requested from MIT, to build up 4 trolley lines in reserved lanes ${ }^{2}$, as an infrastructural intervention that best matches the situation described. The target is to achieve, in the long term, the official type approval of trolley buses on three carriages, $24 \mathrm{~m}$. long, already present in other countries of Europe but which in Italy currently cannot circulate.

This study analyzes three possible solutions for the Val Bisagno trolleybus line and evaluates their economic sustainability according to the indications given in the MIT Annex and in the national legislation relating to this type of infrastructure; the goal is to define, for each solution, the feasibility conditions also for the purpose of identifying which of the three best meets the requirements of the Call and can be proposed by the Municipality of Genoa to MIT.

\section{THE BISAGNO VALLEY AND THE NEW TROLLEYBUS LINE}

According to political initiatives that have also given rise to legitimate aspirations on the part of the

\footnotetext{
1 The PUMS was approved with the Metropolitan Council Resolution no. 20 of 31 July 2019. In relation to the Strategic Plan of the Metropolitan City of Genoa, approved on 21 April 2017, the PUMS represents the implementation of the strategies and lines of action, in a medium-long term time horizon, developing a system vision of urban mobility in the Genoese capital and in the entire metropolitan area (Metropolitan City of Genoa, 2019).

2 The four trolleybus axes are: City center-Prà (Ponente axis); Campi-S. Fruttuoso (Center axis); Piazzale Kennedy (Fiera) Prato (Val Bisagno axis); Center-Nervi (Levante axis).
} 
population, Val Bisagno is by far the priority "area of intervention" on which the greatest expectations on the strengthening of public transport axes are concentrated.

The road conditions of the valley, in fact, are strongly characterized by the difficult morphological conditions, but above all by a dense settlement mesh, in which the road network is absolutely interstitial and subordinate. The banks of the Bisagno river are densely built and dotted with a large number of strategic services for the city, which have however stratified without a parallel adaptation of the supporting infrastructure. An uncontrolled and speculative growth, which took place during the Sixties and Seventies, greatly affected alternatives in future choices that are, actually, very limited. The result is a particularly critical condition, the only one among the macro-areas of the capital that is not served by rail vehicles or highcapacity lines, despite the large number of journeys that take place there.

Going back to the origins of the current anthropic structure of the valley, the timeline reaches 1873, with the annexation of the eastern municipalities of Genoa to the great seafaring city. The annexation was motivated, on the one hand, by the lack of space within the walls and the consequent expansion in the valley (with the construction of some city services), and, on the other, by the need to expand the collection basin of taxes to cover the infrastructural expenses planned for the capital. The territory of the valley is deeply affected by this process which transforms the territory from a typically agricultural site to a peri-urban suburbs. The first intervention "symptom" of this incorporation can be identified in the construction of the Monumental Cemetery of Staglieno, but also in an intense building activity that leads to the establishment of numerous industrial sites, foundries and tanneries. With the second decree of 1926 and the consequent subsequent annexations to the Municipality of Genoa, the valley was further dotted with low-qualification industries and services as well as public economic housing, becoming a real urban area of expansion. But it was mainly after the Second World War (in accordance with the Regulatory Masterplan of 1960) t river. This disorderly transformation has clearly brought with it consequences, often negative: from the most tragic due to hydrogeological instability to the daily inconveniences related to vehicular congestion and safe accessibility.

Then, the industrial development of the city and its demographic and settlement growth, the need to adapt public transport to the growing phenomena of commuting has arisen. In 1878 the first tramway was introduced into the city - initially consisting of a horsedrawn carriage on rails - managed by the French General Company of Tramways, which provided for a widespread diffusion of the rail network that reached Val Bisagno in 1890. In 1895 it improved the service in the valley, extending into Piazza Manin-Staglieno, passing through Via Montaldo, up to San Gottardo and in 1897 a direct service was established between Piazza De Ferrari and Prato. In the first decade of the 1900s the Municipal Administration matured the intention to municipalize the tramway network - until then private and in 1913, even before embarking on a program of acquisitions, started the construction of the so-called "Line A" designed to connect the district of Marassi with that of Quezzi. The strategic predominance of "iron" remains substantially undisputed until 1934, when the so-called "tram reform" is implemented, which gives way to the progressive replacement of the tram, starting from the city center, with road vehicles considered preferable by virtue of the greater flexibility.

From the first buses to trolleybuses, with the construction of the power supply network in 1938, which was followed by a wide diffusion due to the difficulties in supplying fuel for buses. However, the technology is gradually being phased out due to the extensive damage suffered by the network during the world war. In addition, the post-war economic revival renews the paradigms of mobility and, consequently, the conditions of city traffic, for which the bus returns to assume the predominant role leading to the total stop of the trolleybus service in 1973.

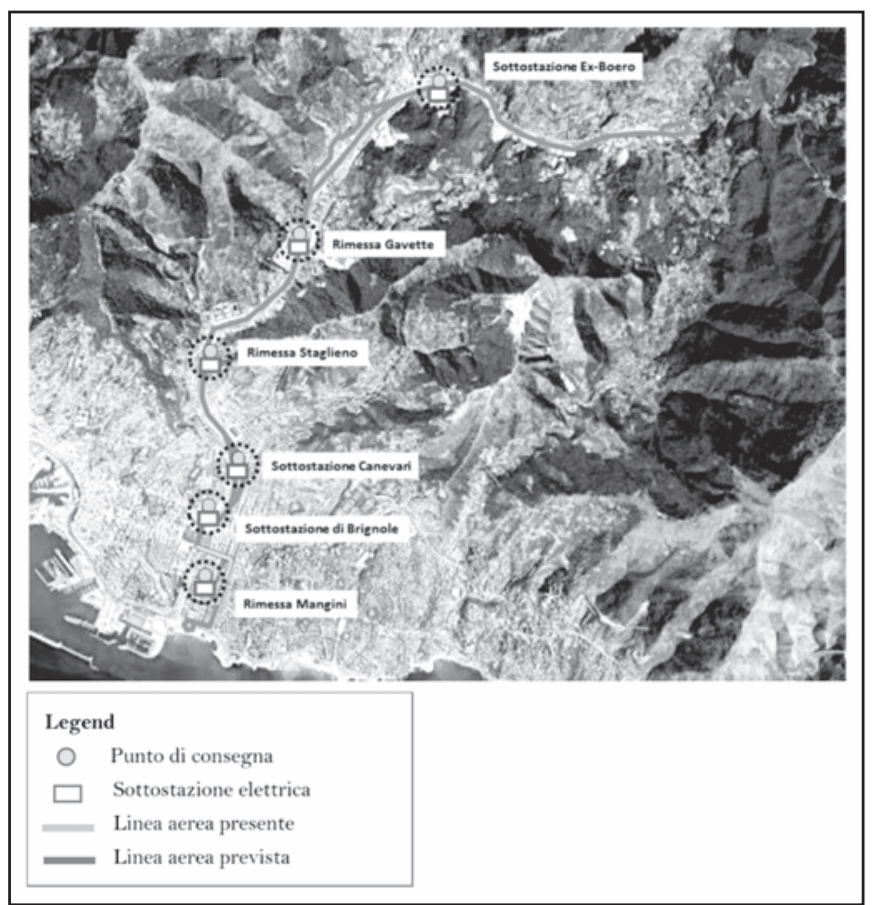

Figure 2 - Trolleybus line powered by overhead line.

The local public transport company (today Azienda Mobilità e Trasporti S.p.A. - AMT) removes the tram lines that remained active on the city traffic routes and in 1966 the last still active section was canceled in Val Bisagno. However, even after those years, two important motivations in support of the extension of the line in the valley are confirmed in the Regulatory Master Plan of the Municipality of Genoa: first of all, the morphology of the territory on the banks of the river implies a high population density (about 300-400 inhabitants per hectare) spread over a strip of about 800 $\mathrm{m}$, with a road network converging on a single (albeit double) valley road. 
Secondly, the importance of a reserved LPT line, characterized by a high attractiveness, which is therefore considered as the ideal solution to satisfy significant amounts of demand.

The requirements of the PUMS resume and substantially confirm this original vision and repropose the axis of force for mass transport, on its own premises. However, the technological choice on the type of vehicles used and their characteristics was accompanied by a broad citizen debate and a careful evaluation of the different solutions (Metropolitan City of Genova, 2019).

As known, trolleybus systems are based on the use of electrically-propelled road vehicles, which are powered by an electrical energy distribution infrastructure. Generally, the collection of electricity takes place through electrical conductors by means of devices called trolley rods or collection rods.

The overhead network consists of a two-wire, that is a double wire hung by a system of cables and tension cables that allow the overhead line to remain in the assigned position even under the strain of its own weight or other climatic conditions, such as the presence of wind.

The need to have a two-wire and not a single wire, as occurs in trams or trains, derives from a question of the composition of the electrical supply circuit system.

In fact, vehicles such as trams or railway engines have a circuit formed not only by the overhead line, but also by the metallic track with which they are in contact via the wheels. In the case of a trolley-bus means of transport, this is not possible because the line does not have rails.

The overhead line is positioned at a height of about 5-6 meters from the roadway, so as not to hinder the normal circulation of other vehicles (such as trucks or vehicles with particular vertical protrusions) and to ensure greater safety of the plant.

The definition of trolly, as it was introduced before, has been undergoing a transformation of concept in recent years, abandoning the close link with the term "wire" towards new innovative technologies in the field of sustainability and environmental protection.

The regulatory reference is the DM. n. 238 of 10/07/2003 "Provisions concerning the validation procedures for trolleybuses for the transport of people", which represents a series of rules to which new trolleybuses and those still in use must refer and, where missing, adapt to the current law.

The selected technical solutions object of this study are:

1. Trolleybus line powered by overhead line;

2. Trolley line with stop charging;

3. Trolleybus line with top-up at the terminus.

The first solution (Figure 2) consists of a two-wire overhead line very similar to the one that currently feeds the only trolleybus line in Genoa (line 20).

The envisaged vehicles would be totally electric, with a length of 24 meters; the transport capacity is equal to 220 passengers per compartment and approximately 4000 passengers per hour. To guarantee the demand during peak hours, 17 trolley buses operating simultaneously on the line would be needed, with a frequency of about 4 minutes ${ }^{3}$.

There are six connection points to the electricity network provided for powering the network ${ }^{4}$.

In order to reduce travel times, the solution also provides for the implementation of a series of changes to the roadway (such as the creation of curbs) to allow for a smoother ride, without interruptions or lane changes.

The second is similar to the previous one, but conceptually the approach is different (Figure 3).

The vehicles used are totally electric as well, but draw energy at predefined points arranged along the route (at the stops) through instant recharge systems (approximately 20 seconds); the bus is therefore equipped with a minimum quantity of batteries, sufficient to allow it to make very limited journeys (about a kilometer). There are 23 battery charging points, each connected to an energy delivery point (12 in total).

The possibility of using small batteries allows to reduce the weight of the vehicle and to have more space for the transport of passengers. The means provided are equally long, with respect to the previous solution (24 m.) and a capacity of about 200 passengers each; to guarantee the transport request, it is estimated that 20 buses circulating simultaneously on the line with a frequency of about 4 minutes ${ }^{5}$.

The third technological solution consists in the possibility of using fully electric buses on the line: they are able to travel the entire route and then recharge at the time of the stop, at the terminus, through a fast charging system, of 5-7 minutes (Figure 4). Unlike the second solution, the vehicles require large-sized batteries arranged in series so as to ensure the vehicle travels along the entire route. Also in this case the buses have a length of 24 meters, but with a slightly lower capacity, equal to about 170 passengers; the autonomy of the batteries (weighing 2.3 tons each) is approximately $230 \mathrm{~km}$. To guarantee the frequency of the service every 4 minutes, an additional recharging point must be provided at the terminus; in this way, while a bus is finishing charging, a second vehicle can start using a second charging station and, therefore, taking the extra time available to recharge. To satisfy the demand, it is estimated that 26 buses running simultaneously on the line are required.

The second and third solutions are therefore very similar from the point of view of the power supply

\footnotetext{
${ }^{3}$ To deal with any breakdowns or malfunctions, the purchase of 20 vehicles is expected.

${ }^{4}$ They guarantee the supply of the energy necessary for the movement of vehicles; they include the transformer, the rectifier and the necessary protection and safety systems. The estimated cost for the construction of each point is 1.5 million euros.

${ }^{5}$ To deal with any breakdowns or malfunctions, 20 vehicles are purchased.
} 


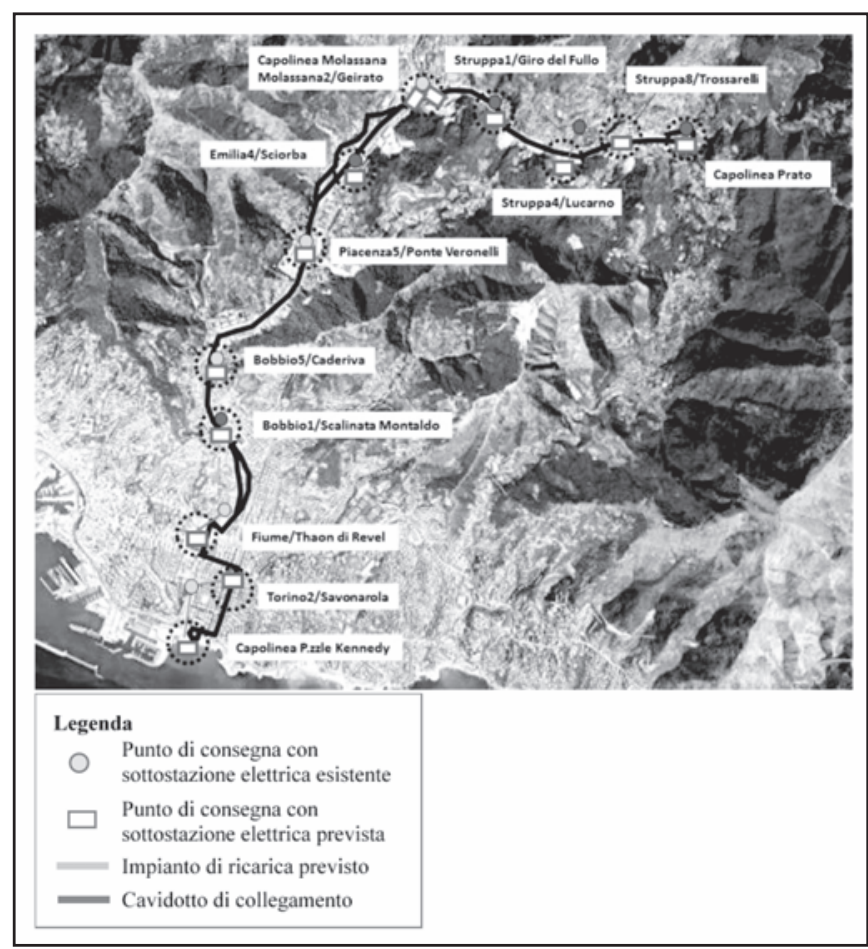

Figura 3 - Linea filoviaria con ricarica a fermata.

mode (with batteries). However, the difference in the insertion of only two charging points (for the one with charging at the terminus) or about 15 (for the one with charging at stop) determines differences, both on a technical-economic and functional level. Furthermore, the support of infrastructures and plant solutions requires different civil works and structures.

\section{THE EVALUATION OF THE THREE MOBILITY SOLUTIONS THROUGH THE COST-BENEFIT ANALYSIS}

The three technical solutions of urban mobility thus defined were then evaluated taking as a reference the indications of the MIT for the selection of urban mobility proposals that can access the economic resources intended for the strengthening and implementation of systems. of rapid mass transport provided for by Law no. 232/2016 and confirmed by the 2018 Budget Law (Law No. 205/2017) ${ }^{6}$.

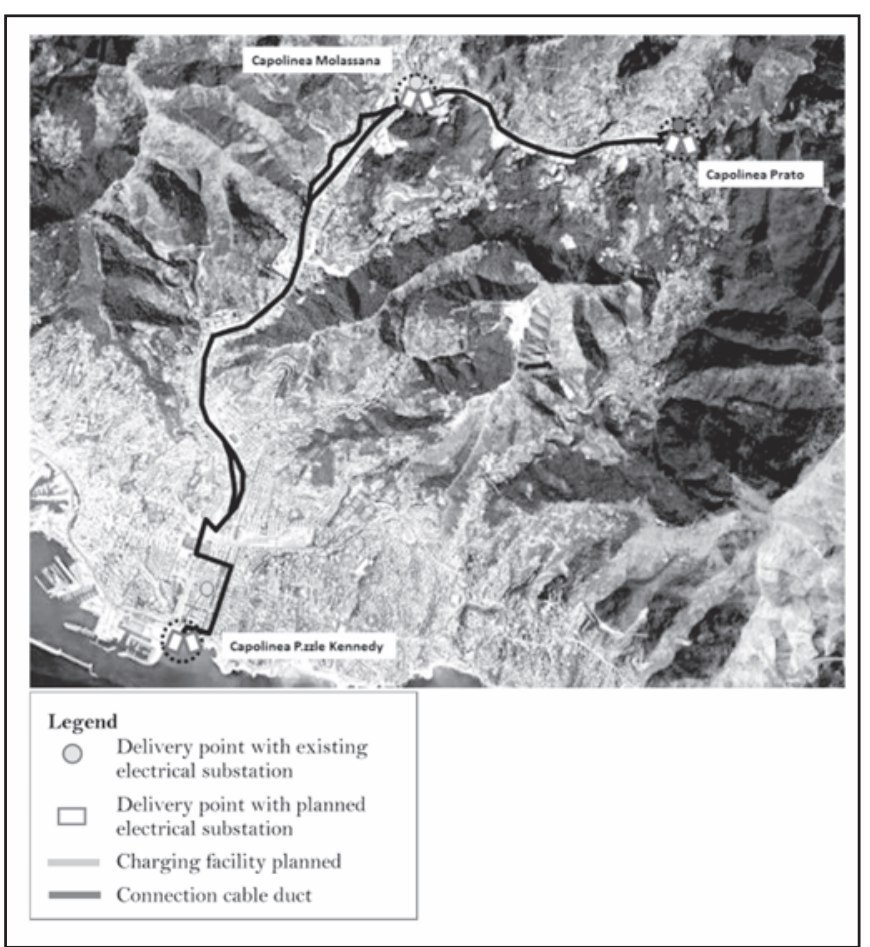

Figure 4 - Trolleybus line with charging at the terminus.

The goal is to determine which of the three solutions has the best relationship between costs and benefits and, therefore, could be presented by the Municipality of Genoa to MIT for the financing of the intervention ${ }^{7}$.

Specifically, Law no. 232/2016 establishes that the projects that can be financed may concern:

- the renewal and improvement of the vehicle fleet;

- the enhancement and enhancement of existing underground lines, tramways and trolleybuses;

- the construction of underground lines, tramways and trolleybuses and extension - or implementation - of the rapid mass transport network, also with innovative fixed systems.

In the notice issued by MIT for the presentation of proposals by local administrations, it is indicated that for new interventions, reference should be made to the legislative provisions of Ministerial Decree no. $300 / 2017^{8}$ which provide that the allocation of state funding is subject to the presentation of feasibility projects (or final projects) of the individual

\footnotetext{
${ }^{7}$ The three mobility proposals were defined within the thesis "Transformations of urban mobility" (candidates: Andrea Marcenaro and Giulio Minuto) discussed in March 2019 at the University of Genoa - Polytechnic School; therefore, they are not to be considered as specific proposals of the Municipality of Genoa.

${ }^{8}$ Guidelines for the Evaluation of Investments in Public Works in the areas of competence of MIT; the latest version was published on 01/06/2017.
} 
infrastructures and a Cost-Benefit Analysis $(A C B)^{9}$. According to the indications of the MIT for infrastructural works that provide for tariff returns, the proposals must provide (Ministero Infrastrutture e Trasporti, 2017a):

- an analysis of the transport demand;

- a financial analysis with which the economic-financial balance of the investment underlying the construction of the work is assessed;

- a Cost-Benefit Analysis;

- a risk and sensitivity analysis.

With regard to the analysis of the demand, this must concern: the "trend" demand (i.e. the number of trips that would occur in a scenario without the construction of the new infrastructure); demand in "modal diversion" (i.e. the number of users who previously used another infrastructure or transport system); "induced" demand (i.e. users who move as a result of the new infrastructure and who previously did not make the move).

The financial analysis must make it possible to assess whether the work is financially sustainable - given the share of public co-financing and the use of debt - and whether the project is bankable in light of current conditions; it must be conducted in relation to possible design alternatives (or scenarios) identified among those that configure efficient and/or effective ways to respond to the specific need.

Among these, the alternative "without intervention" ("do nothing" or "do minimum") must always be considered; it represents the scenario that provides for those investments and maintenance necessary to keep the existing infrastructure in operation without excessive deterioration. This scenario may also include (limited) additional costs or investments already foreseen and planned by the operator ("Business as Usual" scenario). The different alternatives selected to be evaluated must highlight differences in terms of the route, the options for enhancing the service envisaged, the technological and construction process solutions adopted or the management solutions (pricing policies, etc.) (Ministry of Infrastructure and Transport, 2017b).

The methodology to be adopted for the financial analysis foresees that the revenues and costs are determined by applying the incremental method, that is by comparing the revenues and costs in the scenario including the new investment ("scenario with intervention") with the revenues and costs in the

\footnotetext{
${ }_{9}$ Projects must also be consistent with the SUMPs. Furthermore, due to problems of economic sustainability linked to the management of the service, it must also result that the costs of managing the service and infrastructure are covered for at least $35 \%$ by the proceeds deriving from the tariff returns and that the residual share is covered by the Region / or by the institution benefiting from the grant primarily through the reorganization of services following the activation of the new infrastructure.
}

scenario without the new investment (or the "Reference scenario") ${ }^{10}$.

Cash flows must be considered in the year during which they occur and within a reference period that for infrastructural (road and railway) can be assumed equal to 25 years (Ministero Infrastrutture e Trasporti 2017b) ${ }^{11}$.

On the basis of the estimated revenue and costs of the project within the useful life, two profitability indicators are calculated:

- the Financial Net Present Value (FNPV), i.e. the sum of the discounted cash flows at the time of valuation (time "zero");

- the Financial Internal Rate of Return (FIRR), which is the average annual return on the investment.

For the calculation of the two indicators, the discount rate (or discount rate) takes on the meaning of the opportunity cost of the capital employed in the project, understood as the financial return achievable from its best alternative use, at the same expected risk ${ }^{12}$. Starting from the financial analysis, the MIT Guidelines provide for the development of economic analysis; the financial values are transformed into economic values through the application of conversion ${ }^{13}$ factors and the costs and benefits attributable to the investor are added to the benefits and costs of users and the community discounted through no longer by a financial discount rate but by a "social" discount ${ }^{14}$.

At the end of the discounting of the benefits and costs of the project, the following economic and social profitability indicators must be calculated:

- the Economic Net Present Value (ENPV);

- the Economic Internal Rate of Return (EIRR);

\footnotetext{
${ }^{10}$ Both revenues and costs will then have to be calculated at constant prices and net of VAT, except in the event that this tax is not recoverable by the operator of the work.

${ }^{11}$ If the effective economic life of the project exceeds the reference period for the management of the work, it will be necessary to include a residual value among the cash flows relevant for the compilation of the economic and financial plan. According to the indications of the MIT Guidelines (Ministero Infrastrutture e Trasporti, 2017b) this value can be calculated as the difference between the initial cost of the investment and the accumulated depreciation instalments (sometimes referred to as "Depreciation Fund").

${ }^{12}$ According to art. 19 (Discounting of cash flows) of Delegated Regulation (EU) no. 480/2014 of the Commission, for the 20142020 programming period the European Commission recommends considering a financial discount rate of $4 \%$ in real terms as a benchmark for the real opportunity cost of capital in the long term (European Commission, 2014).

${ }^{13}$ The application of conversion factors makes it possible to "correct" the costs used in the financial analysis and obtain amounts net of taxation and distortions due to the malfunctioning of the market (due to the existence of monopoly positions, administered prices, duties or grants).

${ }^{14}$ The European Commission, for the 2014-2020 programming period, recommends using a social discount rate of $3 \%$ (European Commission, 2014).
} 
- the Benefits/Costs ratio (B/C).

With regard to the economic analysis - and in order to facilitate the work by local administrations - the General Directorate for Transport Systems with Fixed Installations and Local Public Transport has signed a memorandum of understanding with the EIB and, in particular, with the "European Investment Advisory Hub (EIAH) for the development of methodological procedures relating to the application of the provisions of the 2017 Guidelines ${ }^{15}$.

\section{THE FINANCIAL AND ECONOMIC EVALUATION OF THE THREE PROJECT SOLUTIONS}

The three technical solutions identified were then evaluated by applying the indications of the MIT Guidelines which provide for the development of a financial and economic Cost Benefit Analysis (CBA). The technique is used to evaluate the economic and financial sustainability of public projects (Nuti, 1987). In the transport sector it has been used in several case studies relating to mobility projects both at urban and extra-urban level (Shefer and Haviram, 2005; Harford, 2006; Godinho and Dias, 2012; Hyard 2012, GonzalezFeliu, 2014; Margorínová and Trojanová, 2017). Some authors have experimented with the application of CBA in combination with other techniques, such as Multicriteria Analysis, for the selection of transport solutions (Tudela, Akiki and Cisternas, 2006; Guhnemann, Laird and Pearman, 2012).

In the case study in question, the purpose of the CBA is to verify which - of the three alternatives identified has the best performance in terms of the indicators reported in the MIT Guidelines.

The financial and economic evaluation is divided into the following phases:

1. identification of the project scenarios to be evaluated;

2. identification of the transport scenario of reference;

3. identification of costs and benefits generated by the three alternatives;

4. calculation of the indicators: Financial and Economic Net Present Value (FNPV - ENPV), Financial and Economic Internal Rate of Return (FIRR - EIRR), Financial and Economic Payback Period (FPBP - EPBP), Financial and Economic Benefits and Costs ratio $(\mathrm{B} / \mathrm{C})^{16}$.

\footnotetext{
15 The memorandum of understanding therefore found application in the Appendix to the Addendum of the MIT notice which contains the "Summary tables of the analysis of urban mobility ACE/ACB - Instructions for compilation". They allow you to acquire an overall picture of the information required for the examination and evaluation of applications.

${ }^{16}$ For greater completeness of the analysis on the economic financial sustainability of each transport solution, in addition to the indicators reported in the MIT Guidelines, the Return Period (both financial and economic) and the financial Benefits and Costs ratio were therefore calculated.
}

The design solutions evaluated through the CBA are 4 in all (Table 1).

Table 1 - Scenarios and related solutions considered

\begin{tabular}{|c|c|c|}
\hline Solution & Name & Features \\
\hline 0 & Business as Usual & $\begin{array}{l}\text { Maintenance of the } \\
\text { means used today } \\
\text { for the connection }\end{array}$ \\
\hline 1 & $\begin{array}{l}\text { Trolleybus line powered } \\
\text { by overhead line }\end{array}$ & $\begin{array}{l}\text { New trolleybus line } \\
\text { with contact- } \\
\text { powered vehicles } \\
\text { (overhead cables) }\end{array}$ \\
\hline 2 & $\begin{array}{l}\text { Trolley line with stop } \\
\text { charging }\end{array}$ & $\begin{array}{l}\text { New trolleybus line } \\
\text { with vehicles } \\
\text { recharged at stops }\end{array}$ \\
\hline 3 & $\begin{array}{l}\text { Trolleybus line with } \\
\text { charging at the terminus }\end{array}$ & $\begin{array}{l}\text { New trolleybus line } \\
\text { with vehicles } \\
\text { recharged at the } \\
\text { terminus }\end{array}$ \\
\hline
\end{tabular}

The solution 0 ("Business as Usual") was introduced in order to develop an "incremental" analysis, in accordance with the indications of the MIT Guidelines (Ministero Infrastrutture e Trasporti, 2017b); it is configured in such a way that the basic functionality of existing transport activities is guaranteed, i.e. the provision of transport services with quality levels similar to those found at the time of design and a limited replacement of vehicles and systems. From the management point of view, it assumes that the level of interventions remains unchanged, maintaining the level of expenditure necessary to guarantee the basic functionality of the public transport system. The transport scenarios were selected on the basis of the forecasts contained in the Urban Mobility Plan (PUM) of 2010 (i.e. the plan prior to the PUMS drawn up in 2018 and approved in 2019, which therefore represents the pre-existing state of planning of the trolleybus proposal) which define a transport structure with and without project; the effects on traffic are considered similar for the different technological solutions being evaluated.

This assumption is motivated by the fact that the characteristics of the service offered are to be considered the same in the three solutions, so the effects on the urban transport system in which they will be inserted are equivalent ${ }^{17}$. Among the transport scenarios reported in the 2010 PUM, the ones that are most appropriate to represent the case study in question were therefore selected.

\footnotetext{
${ }^{17}$ These effects were determined on the basis of a transport model developed by the Company of Apollonia S.p.A. of Genoa for the entire Genoese urban area, according to different levels of intervention provided for by the PUM of the Municipality of Genoa (Municipality of Genoa, 2010).
} 
In particular:

- reference scenario: considers only the projects for which, at the time of drafting the PUM, there were institutional deeds signed by the Municipality of Genoa as well as interventions aimed at guaranteeing the maintenance of sufficient accessibility standards. This scenario does not include the construction of any of the axes of force for LPT and is therefore adopted for the design solution 0 ;

- first stage implementation scenario: consists of the set of interventions that, according to the PUM timeline, are to be carried out in the first five years. This scenario is the one that best approximates the selected design solutions as it only includes interventions on the force axis, the construction of interchange parking lots and the construction of Limited Traffic Zones (LTZ), limited to Val Bisagno. It is therefore assumed as a reference scenario for design solutions 1, 2 and 3 .

The main transport indicators associated with the two different scenarios are shown in Table 2.

Table 2 -Main transport indicators considered

\begin{tabular}{|c|c|c|c|c|}
\hline $\begin{array}{c}\text { Modal } \\
\text { distribution }\end{array}$ & \multicolumn{2}{|c|}{$\begin{array}{l}\text { Private } \\
64.5 \%\end{array}$} & \multicolumn{2}{|c|}{$\begin{array}{l}\text { Private } \\
62.3 \%\end{array}$} \\
\hline $\begin{array}{c}\text { Modal } \\
\text { distribution }\end{array}$ & $\begin{array}{c}\text { Private } \\
64.5 \%\end{array}$ & $\begin{array}{l}\text { Public } \\
35.5 \%\end{array}$ & $\begin{array}{c}\text { Private } \\
62.3 \%\end{array}$ & $\begin{array}{l}\text { Public } \\
37.7 \%\end{array}$ \\
\hline $\begin{array}{l}\text { Average } \\
\text { speed of } \\
\text { private } \\
\text { vehicles }\end{array}$ & $\begin{array}{c}\text { Cars } 23.2 \\
\mathrm{~km} / \mathrm{h}\end{array}$ & $\begin{array}{c}\text { Motor- } \\
\text { cycle } \\
31.5 \mathrm{~km} / \mathrm{h}\end{array}$ & $\begin{array}{c}\text { Cars } \\
23.6 \mathrm{~km} / \mathrm{h}\end{array}$ & $\begin{array}{c}\text { Moto } \\
30.8 \mathrm{~km} / \mathrm{h}\end{array}$ \\
\hline $\begin{array}{l}\text { Average } \\
\text { speed } \\
\text { of public } \\
\text { vehicles }\end{array}$ & $\begin{array}{c}\text { Bus } \\
15.6 \mathrm{~km} / \mathrm{h}\end{array}$ & $\begin{array}{c}\text { Trolleybus } \\
-\end{array}$ & $\begin{array}{c}\text { Bus } \\
15.3 \mathrm{~km} / \mathrm{h}\end{array}$ & $\begin{array}{l}\text { Trolleybus } \\
22.7 \mathrm{~km} / \mathrm{h}\end{array}$ \\
\hline
\end{tabular}

The transport models developed for the PUMS of Genoa show, for the project solutions considered, an increase in the use of LPT due to the greater attractiveness for the new transport system of the Val Bisagno. It captures users not only from the bus but also from motorcycles and cars; as a consequence, there is a slight improvement in the speed of transport by car and a reduction in the speed of two-wheeled vehicles (motorcycles) due to the introduction of lanes protected by curbs that make them unusable by these vehicles.

\subsection{The cost analysis of the three design solutions}

The costs associated with the three design solutions analyzed were estimated by distinguishing them according to 3 categories:

1) Direct investment costs;

2) Operating and maintenance costs;
3) External (indirect) costs.

With regard to direct investment costs, these are relevant to the initial investment costs and additional costs in the course of business of the company, the socalled "Capex"18. In particular, the initial costs for the construction of civil works and systems to support the lines were quantified (interventions on the roadway, adaptation of stops and removal of architectural barriers, signs, plant engineering, etc.) and for the purchase means (including any adaptation works to the technical solution adopted) (Table 3) ${ }^{19}$.

Table 3 - Investment costs of the analysed solutions

\begin{tabular}{|c|c|c|c|}
\hline Trolleybus solution & $\begin{array}{c}\text { Unitary cost } \\
\text { trolleybus } \\
(€ / \text { each) }\end{array}$ & $\begin{array}{c}\text { Number } \\
\text { of } \\
\text { vehicles } \\
(\mathbf{n} \text {. })\end{array}$ & $\begin{array}{c}\text { Total } \\
\text { eligible cost } \\
(€)\end{array}$ \\
\hline $\begin{array}{c}1 \text { - With overhead } \\
\text { line power supply }\end{array}$ & $1,000,000$ & 20 & $20,000,000$ \\
\hline $\begin{array}{c}2 \text { - With stop } \\
\text { charging }\end{array}$ & $1,200,000$ & 23 & $27,600,000$ \\
\hline $\begin{array}{c}3 \text { - With charging at } \\
\text { the terminus }\end{array}$ & $1,200,000$ & 30 & $36,000,000$ \\
\hline
\end{tabular}

As regards the operating and replacement costs ${ }^{20}$, these were estimated both for the vehicles used in each project solution and for those operating on the main $\left(13,14\right.$ and) and secondary (hilly) bus lines (Table 4) ${ }^{21}$. In particular, for lines 13 and 14 replacement costs are considered only for the "Business as Usual" solution while for the secondary ones they have been considered in all the solutions analyzed. To this end, the secondary bus lines were analysed both in the current situation (Fig. 6 - left) and in the project (Fig. 6 - right), i.e. modified taking into account the insertion of the new trolleybus line. The new routes of the secondary lines have been designed in order to minimize inefficient routes, also trying to connect the hilly lines directly with the main force axis (new trolleybus); this led to the suppression of lines 482 (doubling the frequency of line 480) and of the barred 470. It should be noted that according to the scenario configured by the PUM of Genoa in 2010 (Municipality of Genoa,

\footnotetext{
${ }^{18}$ Contraction from "CAPital Expenditure.

${ }^{19}$ All costs relating to the construction and/or adaptation of the structures for the shelter of vehicles (remittances) and the related costs for their infrastructure are not considered in this analysis.

${ }^{20}$ Replacement costs are those necessary for the replacement of vehicles (buses, trolleybuses) and components (batteries, etc.) at the end of their useful life.

${ }^{21}$ These lines connect the city center with the Struppa district, on the north-eastern border of the Municipality of Genoa, passing along the entire Val Bisagno along the road axis on the right bank of the Bisagno river.
} 
Table 4 - Operating and maintenance costs of the analysed solutions

\begin{tabular}{|c|c|c|c|}
\hline $\begin{array}{l}\text { Trolleybus } \\
\text { solution }\end{array}$ & $\begin{array}{l}\text { Annual } \\
\text { unitary } \\
\text { cost }\end{array}$ & Quantity & $\begin{array}{l}\text { Total cost (net } \\
\text { of VAT) }\end{array}$ \\
\hline \multicolumn{4}{|c|}{1 - Business as Usual (Existing bus line) } \\
\hline $\begin{array}{l}\text { Exercise } \\
\text { (gasoline supply) }\end{array}$ & $\begin{array}{c}1.4 \\
€ / \mathrm{Km}\end{array}$ & $\begin{array}{l}\text { 4,010,000 } \\
\text { Km/year }\end{array}$ & $\begin{array}{c}5,614,000 \\
€ / \text { year }\end{array}$ \\
\hline $\begin{array}{l}\text { Vehicles } \\
\text { maintenance }\end{array}$ & $\begin{array}{c}0.45-0.65 \\
€ / \mathrm{Km}\end{array}$ & $4,010,000$ & $\begin{array}{c}2,274,500 \\
€ / \text { year }\end{array}$ \\
\hline $\begin{array}{l}\text { Vehicles } \\
\text { replacement }\end{array}$ & $\begin{array}{l}185,000- \\
340,000 \\
€ / \text { each }\end{array}$ & 72 & $\begin{array}{c}17,809,200 \\
€\end{array}$ \\
\hline \multicolumn{4}{|c|}{2 - With overhead line power supply } \\
\hline $\begin{array}{l}\text { Exercise (energy } \\
\text { supply) }\end{array}$ & $0.7 € / \mathrm{Km}$ & $\begin{array}{l}\text { 1,854,200 } \\
\text { Km/year }\end{array}$ & $\begin{array}{c}1,297,940 \\
€ / \text { year }\end{array}$ \\
\hline $\begin{array}{l}\text { Vehicles } \\
\text { maintenance }\end{array}$ & $\begin{array}{c}26,500 \\
€ / \text { each year }\end{array}$ & 20 & $\begin{array}{l}530,000 \\
€ / \text { year }\end{array}$ \\
\hline $\begin{array}{l}\text { Vehicles } \\
\text { replacement }\end{array}$ & $\begin{array}{c}1,000,000 \\
€ / \text { each }\end{array}$ & 20 & $\begin{array}{c}20,000,000 \\
€\end{array}$ \\
\hline $\begin{array}{l}\text { Battery } \\
\text { replacement }\end{array}$ & $\begin{array}{l}55,000 \\
€ / \text { each }\end{array}$ & 22 & $\begin{array}{c}1,100,000 \\
€\end{array}$ \\
\hline $\begin{array}{l}\text { Airline } \\
\text { replacement }\end{array}$ & $500,000 € / \mathrm{Km}$ & $23 \mathrm{Km}$ & $\begin{array}{c}11,500,000 \\
€\end{array}$ \\
\hline \multicolumn{4}{|c|}{3 - With stop charging } \\
\hline $\begin{array}{l}\text { Exercise (energy } \\
\text { supply) }\end{array}$ & $0.85 € / \mathrm{Km}$ & $\begin{array}{l}\text { 1,854,200 } \\
\text { Km/year }\end{array}$ & $\begin{array}{c}1,576,070 \\
€ / \text { year }\end{array}$ \\
\hline $\begin{array}{l}\text { Vehicles } \\
\text { maintenance }\end{array}$ & $\begin{array}{c}35,000 \\
\text { €leach year }\end{array}$ & 23 & $\begin{array}{c}805,000 \\
€ / \text { year }\end{array}$ \\
\hline $\begin{array}{l}\text { Vehicles } \\
\text { replacement }\end{array}$ & $\begin{array}{c}1.100 .000 \\
€ / \text { each }\end{array}$ & 23 & $\begin{array}{c}25,300,000 \\
€\end{array}$ \\
\hline $\begin{array}{l}\text { Battery } \\
\text { replacement }\end{array}$ & $\begin{array}{l}110,000 \\
€ / \text { each }\end{array}$ & 25 & $\begin{array}{c}2,750,000 \\
€\end{array}$ \\
\hline $\begin{array}{l}\text { Replace charging } \\
\text { stations }\end{array}$ & $\begin{array}{l}170,000 \\
€ / \text { each }\end{array}$ & 23 & $\begin{array}{c}4,140,000 \\
€\end{array}$ \\
\hline \multicolumn{4}{|c|}{4 - With charging at the terminus } \\
\hline $\begin{array}{l}\text { Exercise (energy } \\
\text { supply) }\end{array}$ & $0.85 € / \mathrm{Km}$ & $\begin{array}{l}\text { 1,854,200 } \\
\text { Km/year }\end{array}$ & $\begin{array}{l}1,576,070 \\
€ / \text { year }\end{array}$ \\
\hline $\begin{array}{l}\text { Vehicles } \\
\text { maintenance }\end{array}$ & $\begin{array}{c}35,000 \\
€ / \text { each year }\end{array}$ & 30 & $\begin{array}{c}1,050,000 \\
€ / \text { year }\end{array}$ \\
\hline $\begin{array}{l}\text { Vehicles } \\
\text { replacement }\end{array}$ & $\begin{array}{c}1,200,000 \\
€ / \text { each }\end{array}$ & 30 & $\begin{array}{c}36,000,000 \\
€\end{array}$ \\
\hline $\begin{array}{l}\text { Battery } \\
\text { replacement }\end{array}$ & $\begin{array}{l}110,000 \\
€ / \text { each }\end{array}$ & 32 & $\begin{array}{c}3,520,000 \\
€\end{array}$ \\
\hline $\begin{array}{l}\text { Replacements of } \\
\text { the charging } \\
\text { terminal }\end{array}$ & $\begin{array}{l}180,000 \\
€ / \text { each }\end{array}$ & 6 & $\begin{array}{c}1,080,000 \\
€\end{array}$ \\
\hline
\end{tabular}

2010), many of the hilly lines will no longer operate alone but will be supported by the Demand Responsive Transport system (DRT). In relation to the long period of reference, the replacements of the plant equipment accompanying the lines are also considered; these include the costs of battery replacements, estimated on the basis of an analysis conducted with suppliers of this type of component.

For operating costs, the costs of running and feeding the vehicles were considered; the difference in costs for powering the electric or thermal engine vehicles was therefore considered, while the costs associated with the driver were considered equal. Within this group of costs are also included those relating to vehicle insurance and the state property tax.

For ordinary maintenance costs, those relating to vehicle maintenance were considered, i.e. both interventions relating to periodic maintenance actions and interventions aimed at restoring the components of the vehicles from a state of failure to a state of good functioning; as regards extraordinary maintenance costs, these were considered included in the policies or leasing contracts stipulated with the companies supplying the vehicles ${ }^{22}$.

The costs considered in the CBA are the "eligible" costs, i.e. net of taxation (VAT).

For "external" costs, on the other hand, all the costs incurred by that part of the community affected by the design solutions were considered ${ }^{23}$.

The first group of costs considered is constituted by the so-called "consumer costs", among which the costs relating to travel times and the operating costs of private vehicles are of particular importance.

In the first case, they were assessed using an hourly price determined on the basis of the procedure adopted by the PUMS of the Metropolitan City of Genoa in 2018: starting from the Ligurian annual Gross Domestic Product (GDP) per capita (from ISTAT source), the amount of GDP per employee was calculated and, on the basis of the annual hours of work, the average hourly value was therefore deduced, equal to approximately 36.29 euros.

The percentages of travel taken as a reference for the application of the costs incurred by citizens are as follows (Municipality of Genoa, 2010):

- journeys for "Work": 14\%;

- trips for "Business": 22\%;

- trips for "Other reasons": $8 \%$.

${ }^{22}$ The operating and maintenance costs have been quantified on the basis of the indications and data provided by AMT, which carries out the LPT service. Depending on the nature of the cost, this has been quantified as a cost per vehicle (€/vehicle) or a cost per $\mathrm{km}$ (€/ km of line).

${ }^{23}$ In the economic analysis, the estimate of the costs and benefits affecting the community was made with reference to the indications contained in the MIT Guidelines (Ministero Infrastrutture e Trasporti, 2017b), considering the users of the transport lines of the analyzed territorial area (current and induced), of road users and the community (residents) in terms of noise and air pollution. 
Then the travel times of the routes were calculated with the different means considered in the analysis (car, scooter, bus and trolleybus) deduced from the average speeds reported in the transport simulation adopted, both in the design scenario and in the "Business as Usual".

The percentages relating to the modal split were then applied to the passenger volumes taken as a reference for the calculation of revenues, thus obtaining the passenger volumes relating to the various categories of private vehicle.

By relating these quantities to the reasons for the trips, the overall costs incurred for travel times were then estimated $^{24}$.

\subsection{The analysis of the benefits of the three design solutions}

The revenues are represented by all the positive items in the balance sheet that essentially derive from two factors: ticketing and the residual values of the means at the end of the time interval considered in the financial and economic analysis (25 years).

With regard to ticketing, public transport users have been distinguished according to the ticket ${ }^{25}$ : holders of hourly tickets; holders of a monthly pass; holders of an annual pass. The total amount is therefore calculated considering both the number of users who already use the means of the lines concerned and the new users

\begin{abstract}
${ }^{24}$ The costs for travel times calculated are: 5.1/hour for business trips; 8.0 /hour for business trips; 2.9 /hour for travel for other reasons.

25 The contribution was determined considering that within the time period of validity of the ticket ( 100 minutes) it is possible to make a trip on the entire route in question. The different rates of travel tickets were provided by AMT.
\end{abstract}

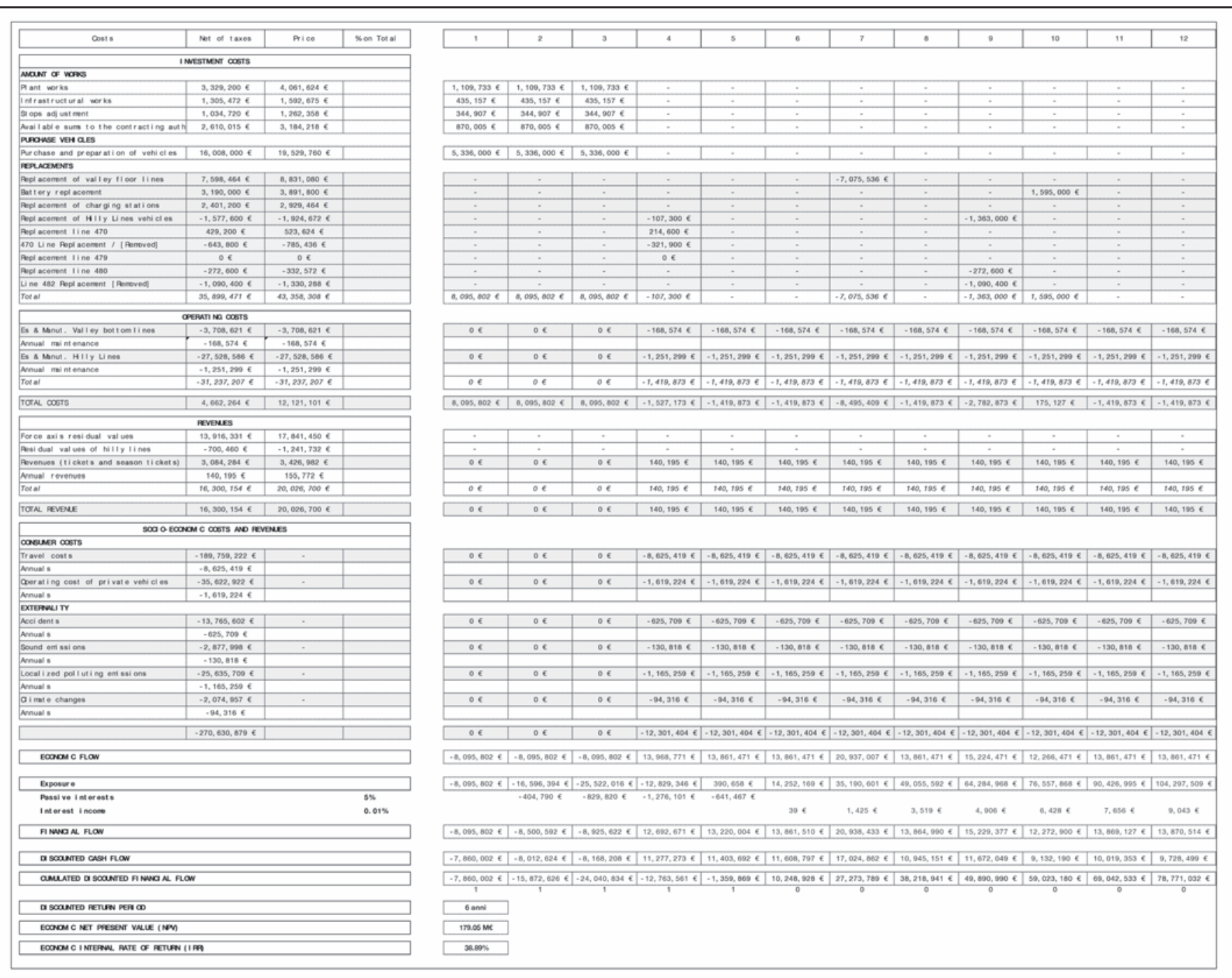

Figure 5a - Economic Cost-Benefit Analysis for the solution with stop charging (solution 2). 
Sustainable mobility and economic sustainability: the case of the new trolleybus line in Genoa

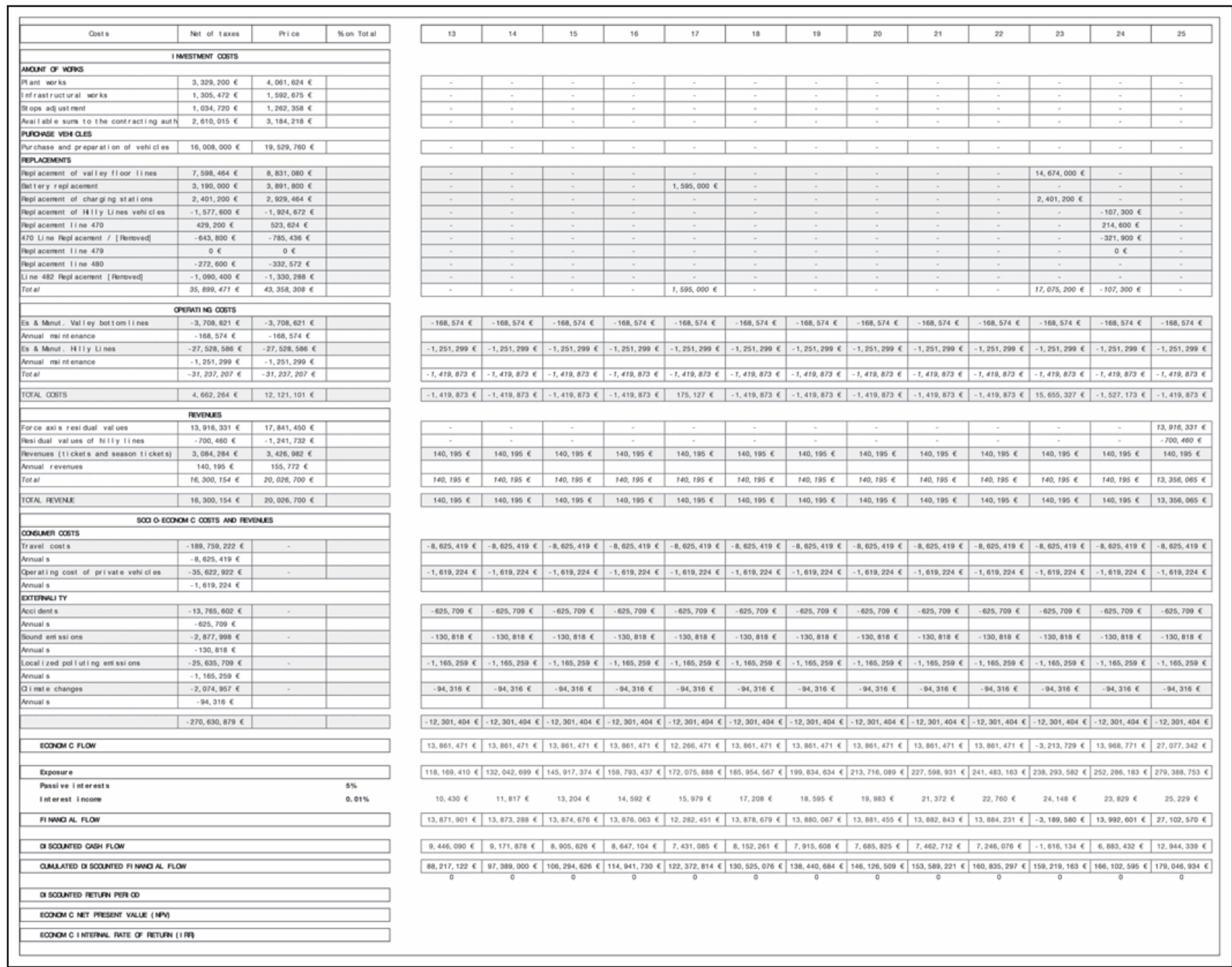

Figure 5b - Economic Cost-Benefit Analysis for the solution with stop charging (solution 2).

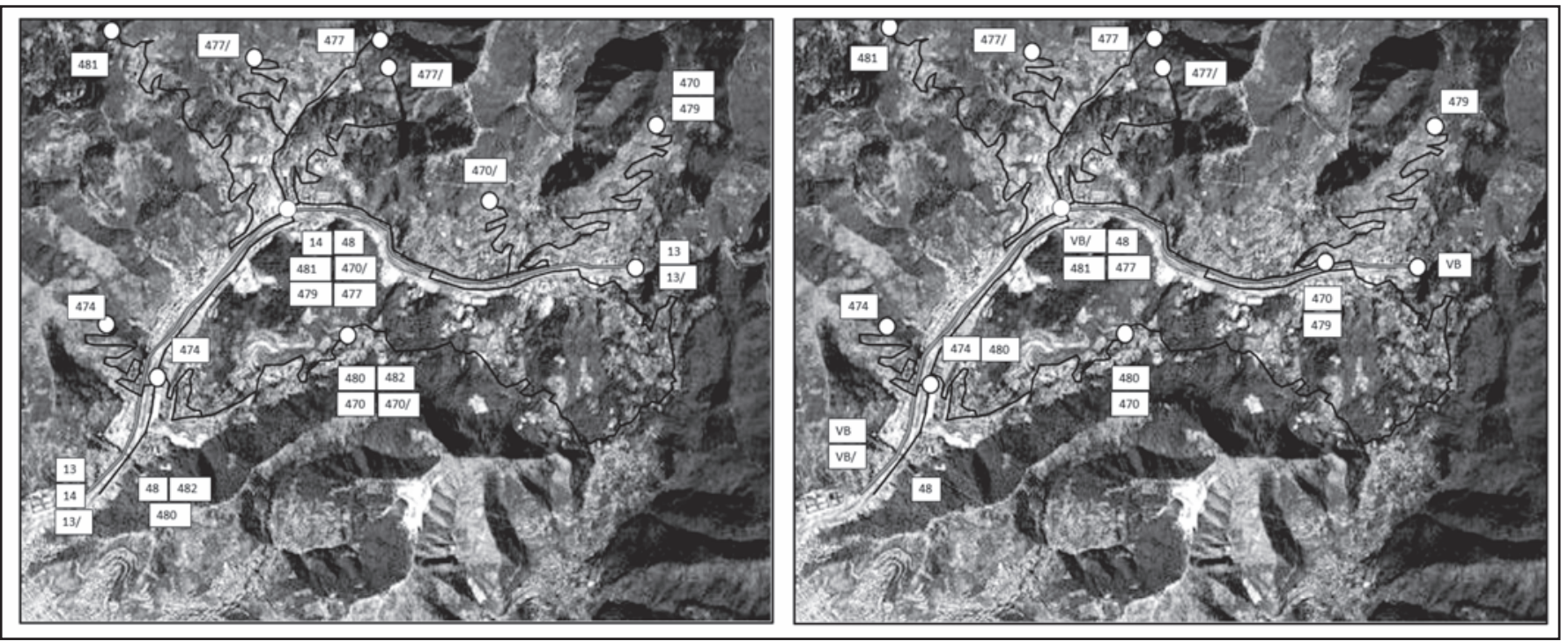

Figure 6 - Existing (left) and project (right) bus lines (black lines) around the new trolleybus line at the bottom of the valley. 
generated by the project solutions, assuming similar percentages of distribution of the three types of travel tickets. In particular, the data relating to the average distribution of the flows of people along the route measured by AMT with the load sections method were used, thus quantifying the daily quantity of journeys to be multiplied by the different rates of travel tickets.

For scenario 0 ("Business as Usual") it was assumed that the users of the lines remained unchanged, thus assuming the data recorded periodically by AMT regarding the number of users on the lines; for the project hypotheses, on the other hand, increases in the number of users were estimated based on the modal split percentages defined for the transport scenarios analyzed. For new users, the same breakdowns of the travel tickets and the same prices of the tickets recorded in 2019 were applied.

Table 5 shows the revenues for the trolleybus line with stop charging.

Table 5 - Expected revenue for the trolleybus with stop charging (solution 2)

\begin{tabular}{|c|c|c|c|c|}
\hline \multirow{2}{*}{ Items } & $\begin{array}{l}\text { Evaders } \\
(25 \%)\end{array}$ & $\begin{array}{l}\text { With } \\
\text { ticket } \\
(19 \%)\end{array}$ & $\begin{array}{c}\text { Montly } \\
\text { subscribers } \\
(29 \%)\end{array}$ & $\begin{array}{c}\text { Annual } \\
\text { subscribers } \\
(30 \%)\end{array}$ \\
\hline & $\begin{array}{c}\text { Title } \\
\text { cost } \\
\text { (€/year) }\end{array}$ & $\begin{array}{l}\text { Daily } \\
\text { values } \\
\text { (n) }\end{array}$ & $\begin{array}{c}\text { Annaul } \\
\text { values (n) }\end{array}$ & $\begin{array}{l}\text { Earn } \\
(€ / \text { year })\end{array}$ \\
\hline New road users & & 996 & & 233,419 \\
\hline $\begin{array}{l}\text { Evaders (without } \\
\text { ticket) }\end{array}$ & 0 & 249 & 90,885 & 0 \\
\hline With ticket & 1.5 & 187 & 68,164 & 102,246 \\
\hline $\begin{array}{l}\text { With monthly } \\
\text { subscription }\end{array}$ & 46 & 131 & 1,569 & 72,160 \\
\hline $\begin{array}{l}\text { With annual } \\
\text { subscription }\end{array}$ & 395 & 149 & 149 & 59,013 \\
\hline $\begin{array}{l}\text { New user } \\
\text { generated }\end{array}$ & 1.5 & 150 & & 35,153 \\
\hline $\begin{array}{l}\text { Evaders (without } \\
\text { ticket) }\end{array}$ & 0 & 38 & 13,688 & 0 \\
\hline With ticket & 1.5 & 28 & 10,266 & 15,398 \\
\hline $\begin{array}{l}\text { With monthly } \\
\text { subscription }\end{array}$ & 48 & 20 & 236 & 10,868 \\
\hline $\begin{array}{l}\text { With annual } \\
\text { subscription }\end{array}$ & 395 & 23 & 23 & 8,888 \\
\hline $\begin{array}{l}\text { Public transport } \\
\text { users }\end{array}$ & & 16,725 & & $4,949,764$ \\
\hline $\begin{array}{l}\text { Evaders(without } \\
\text { ticket) }\end{array}$ & 0 & 4,181 & $1,526,156$ & 0 \\
\hline With ticket & 1.5 & 5,018 & $1,831,388$ & $2,747,081$ \\
\hline $\begin{array}{l}\text { With monthly } \\
\text { subscription }\end{array}$ & 46 & 2,195 & 26,342 & $1,211,726$ \\
\hline $\begin{array}{l}\text { With annual sub- } \\
\text { scription }\end{array}$ & 395 & 2,509 & 2,509 & 990,956 \\
\hline
\end{tabular}

With regard to the residual values of the means, it was assumed that the depreciation is linear and that the value at the end of the useful life is equal to zero. For the purposes of developing the CBA model and calculating the sustainability indicators, a useful life of 20 years was considered for the vehicles purchased, with their replacement therefore scheduled at the end of the 23rd year.

Table 6 shows the revenues from the design solution of the trolleybus line with stop charging.

Tabella 6 - Valori residui previsti per la filoviaria con ricarica a fermata (soluzione 2)

\begin{tabular}{l|c|c|c|c}
\multicolumn{1}{c|}{ Items } & $\begin{array}{c}\text { Total } \\
(€)\end{array}$ & $\begin{array}{c}\text { Useful } \\
\text { life } \\
(\mathbf{n} \text {. of } \\
\text { years })\end{array}$ & $\begin{array}{c}\text { Years } \\
\text { remai- } \\
\text { ning } \\
(\mathbf{n} .)\end{array}$ & $\begin{array}{c}\text { Residual } \\
\text { value } \\
(€)\end{array}$ \\
\hline Station charging & $5,050,800$ & 20 & 18 & $4,545,720$ \\
\hline Trolleybus vehicles & $30,866,000$ & 20 & 18 & $27,779,400$ \\
\hline Vehicles batteries & $3,355,600$ & 7 & 3 & $1,437,857$ \\
\hline $\begin{array}{l}\text { Transport lines } \\
\text { hilly }\end{array}$ & & & & \\
\hline $\begin{array}{l}\text { Vehicles lines } \\
\text { 470-470/ }\end{array}$ & $1,128,500$ & 20 & 4 & 225,700 \\
\hline $\begin{array}{l}\text { Vehicles Lines } 479 \\
\text { Vehicles Lines }\end{array}$ & 902,800 & 20 & 4 & 180,560 \\
\hline $480-482$ & $1,720,200$ & 20 & 9 & 774,090 \\
\hline
\end{tabular}

\subsection{The calculation of the economic and financial sustainability indicators}

For each of the solutions considered, a CBA model was therefore developed according to the two different approaches indicated in the MIT Call:

1) financial, i.e. taking into account only the costs and revenues relevant to the local transport company (AMT) that will develop the investment;

2) economic, i.e. taking into account the costs and benefits that the AMT company and the community derive from the new transport infrastructure.

For each of the three solutions considered, the CBA models were developed with reference to scenario 0 ("Business as Usual"); the cost and revenue values entered as inputs to the model are therefore the differences in costs and revenues between the project scenario and the 0 scenario ("Business as Usual").

\subsection{Results}

The CBA models developed for each of the three transport solutions considered show financial nonsustainability for all three solutions analyzed while - on the other hand - also considering the "external" effects generated (economic analysis), all solutions are 
sustainable. The deviations in the values of the indicators between these two analyzes are considerable, due to the high contribution of the environmental and social benefits derived (Table 7).

Table 7 - Results of the financial and economic sustainability indicators obtained for the three project solutions

\begin{tabular}{|c|c|c|c|c|}
\hline \multicolumn{5}{|l|}{ FINANCIAL ANALYSIS } \\
\hline Trolleybus solution & $\begin{array}{l}\text { FNPV } \\
\text { (millions } \\
\text { of } € \text { ) }\end{array}$ & $\begin{array}{c}\text { FIRR } \\
(\% \\
\text { annual) }\end{array}$ & $\begin{array}{c}\text { Pay Back } \\
\text { Period } \\
\text { (years) }\end{array}$ & $\mathrm{B} / \mathrm{C}$ \\
\hline $\begin{array}{l}1 \text { - With overhead line } \\
\text { power supply }\end{array}$ & -51.10 & -10.03 & no & 0.36 \\
\hline 2 - With stop charging & -28.46 & -3.61 & no & 0.56 \\
\hline $\begin{array}{l}3 \text { - With charging at the } \\
\text { terminus }\end{array}$ & -49.22 & - & no & 0.34 \\
\hline \multicolumn{5}{|l|}{ ECONOMIC ANALYSIS } \\
\hline Trolleybus solution & $\begin{array}{l}\text { FNPV } \\
\text { (millions } \\
\text { of } € \text { ) }\end{array}$ & $\begin{array}{c}\text { FIRR } \\
(\% \\
\text { annual) }\end{array}$ & $\begin{array}{c}\text { Pay Back } \\
\text { Period } \\
\text { (years) }\end{array}$ & $\mathrm{B} / \mathrm{C}$ \\
\hline $\begin{array}{l}1 \text { - With overhead line } \\
\text { power supply }\end{array}$ & 188.16 & 31.94 & 6 & 6.61 \\
\hline 2 - With stop charging & 179.05 & 38.89 & 6 & 7.98 \\
\hline $\begin{array}{l}3 \text { - With charging at the } \\
\text { terminus }\end{array}$ & 173.22 & 37.20 & 6 & 6.98 \\
\hline
\end{tabular}

With regard to the financial analysis, all the NPVs are negative with a fluctuation ranging from -51.10 million euros for solution 1 (with power from the airline) to 28.46 million euros for solution 2 (with top-up at stop); in accordance with the negative values of the NPV, the indicator relating to the ratio between benefits and discounted costs $(\mathrm{B} / \mathrm{C})$ always assumes values below unity.

The difference in the results obtained can be explained essentially in the difference in investment costs (and in particular in the number of vehicles to be purchased) and, for solution 1, in the high cost of building the overhead line (about 700 thousand euros per kilometre).

As for the TIRFs, on the other hand, these have negative values for solutions 1 and 2 (respectively $-10.03 \%$ and $3.61 \%$ ) while they do not exist only for solution 3 as the function of the VANF is always negative ${ }^{26}$.

26 In this type of investments made by public transport companies, the minimum acceptable FIRR can be assumed to be equal to the interest rate paid for the financing of the works and the purchase of the necessary means.
All three solutions have a payback period exceeding the useful life of the means of transport used (20 years).

As regards the economic analysis, this highlights a sustainability for all three solutions: the VANE are largely positive (they range between 173.22 million euros for solution 3 and 188.16 million euros for solution 1) while the annual TIRE are largely positive (they range between $31.94 \%$ of solution 1 and $38.89 \%$ of solution 2).

Overall, the social benefits deriving from the adoption of a trolleybus between the city center (Brignole) and Prato (at the north border of the municipality) and along the Val Bisagno leads to average annual benefits for the community of about 12 million euros: of these, about $60 \%$ derive from the time savings that they have the users who use this infrastructure in moving between the two terminus, while the remaining $40 \%$ relate to benefits deriving from less noise and atmospheric pollution, climate benefits and less accidents for road users.

In order to verify the financial conditions that would guarantee a balance between investment costs and benefits for the investor (AMT), the minimum amount of the public contribution (provided by MIT) in capital account - non-repayable was calculated - necessary to return the investment.

In the CBA model, this contribution was considered as available in the first year and, therefore, goes to reduce the investment costs necessary for the construction of the works and the purchase of vehicles; for the purposes of the calculation it was set that the return on investment period is equal to the useful life of the means (20 years).

Table 8 shows that the solution with stop charging would require a non-repayable public grant of 16.00 million euros, lower than the other two solutions (23.20 and 23.50 million euros respectively for the solution with power supply from overhead line and with charging at the terminus). With these contributions, the return periods are close to the useful life of the vehicles used for each transport solution analysed.

Table 8 - Minimum non-repayable financial contribution for each project solution

\begin{tabular}{l|c|c}
\hline Trolleybus solution & $\begin{array}{c}\text { Non-repayable } \\
\text { grant } \\
\text { (millions of } € \text { ) }\end{array}$ & $\begin{array}{c}\text { Pay Back } \\
\text { Period } \\
\text { (years) }\end{array}$ \\
\hline $\begin{array}{l}1 \text { - With overhead line } \\
\text { power supply }\end{array}$ & 23.20 & 20 \\
\hline 2 - With stop charging & 16.00 & 20 \\
\hline $\begin{array}{l}3 \text { - With charging at the } \\
\text { terminus }\end{array}$ & 23.50 & 20 \\
\hline
\end{tabular}

\section{ANALYSIS OF SENSITIVITY AND MONTE CARLO}

In order to verify the influence of the input variables on the economic feasibility of the solution that has the best 
financial performance (solution 2 - with stop charging), a sensitivity analysis was therefore developed. In particular, the main variables (cost and revenue) were made to vary (one at a time) by applying a percentage variation (positive and negative up to a maximum of \pm $20 \%$ ) to the initial input values and calculated the corresponding variations (always percentages) of the NPV.

The non-repayable grant was instead considered fixed in its minimum amount as it is considered essential for the NPV to be close to zero.

The variable that most influences the value of the NPV is the cost of acquiring the means, estimated at approximately 33.6 million euros; as can be seen from Figure 7 , a 20\% cost increase (44.4 million euros) leads to a FNPV of -11.12 million euros, a value that would compromise the financial feasibility of the project.

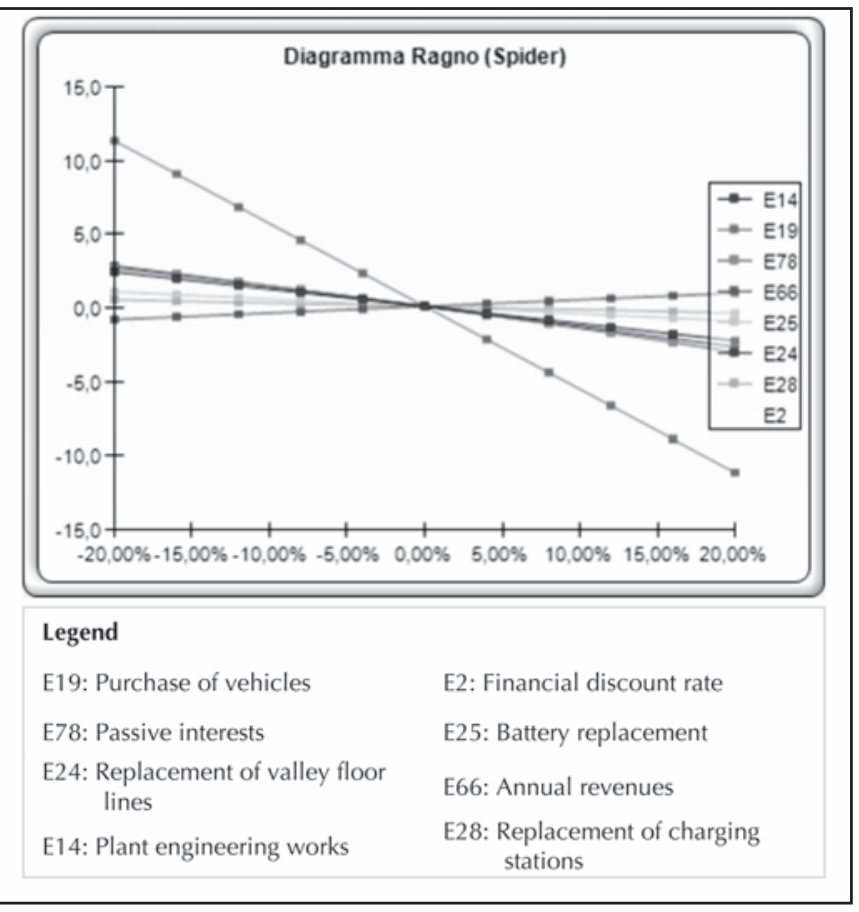

Figure 7 - Sensitivity analysis of the main input variables.

The FNPV is less sensitive than the other variables, even if extreme negative variations lead to negative values of the indicator.

According to the MIT Guidelines (Ministero Infrastrutture e Trasporti, 2014), a risk analysis was therefore developed in order to verify the reliability of the results obtained from the main financial sustainability indicator (FNPV); to this end, the Monte Carlo analysis was applied to the main input variables. The analysis is based on an algorithm that generates a series of unrelated numbers that follow the probability distribution hypothesized for the phenomenon under investigation (normal distribution); the correlation between the numbers is ensured by a chi-square test ${ }^{27}$. The results obtained from the Monte Carlo analysis show that there is a probability of $49.55 \%$ (Figure 8 ) that the FNPV is less than the minimum value set for the sustainability of the investment (equal to approximately 110 million euros which is obtained with a public grant of $€ 16$ million); this percentage shows that it is necessary for the investor to have a greater nonrepayable contribution margin, which makes it possible to deal with any negative scenarios (simultaneous increase in the costs of carrying out civil works, plant engineering works, the purchase price of the vehicles, decrease in ticketing revenues, etc.) which could generate financial problems during the management period of the transport infrastructure. To this end, the contribution that would make it possible to reduce the risk to a minimum was calculated; through the calculation model it has been estimated that by increasing the non-repayable contribution by only 2 million euros, the probability that the FNPV falls below the minimum value set is only $8.65 \%$.

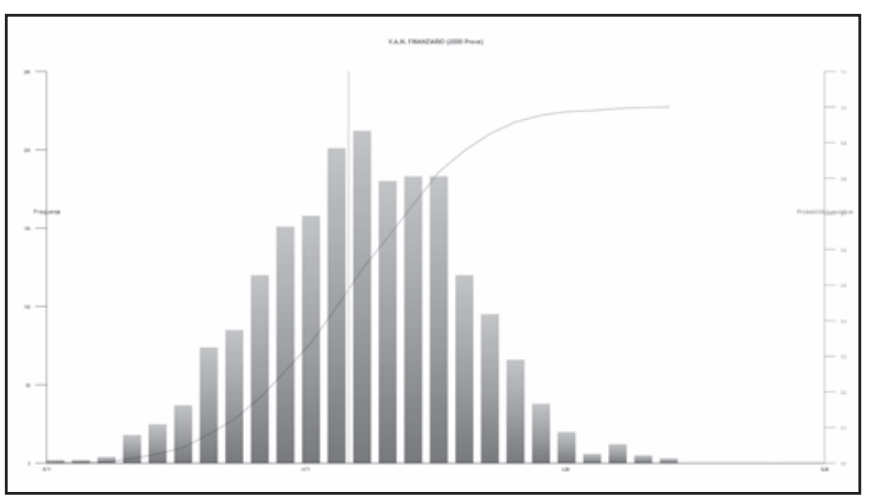

Figure 8 - Results of the Monte Carlo analysis.

With a contribution of around 18 million euros (equal to approximately $16.3 \%$ of the total investment), the investor - in relation to the costs of the trolleybus only is therefore fully guaranteed to be able to deal with any negative scenarios and not only return the investment before the end of the useful life of the vehicles (equal to 20 years) but manages, at least in part, to finance part of the cost of purchasing the new vehicles (about 4).

\section{CONCLUSION}

This paper deals with CBA as a support tool for investment decisions in the local transport sector, for the purpose not only of evaluating which solution has the best relationship between benefits and costs, but also for quantifying the public economic contribution that is necessary for feasibility of the economic investment by the local transport company (AMT).

The case study in question was inspired by the MIT Call

\footnotetext{
${ }^{27}$ For each input variable a possible maximum variation of \pm $20 \%$ has been set (with single increments and decrements of \pm $5 \%$ ), while the maximum number of simulations is equal to 5,000 .
} 
for the financing of local transport projects presented by local administrations; in particular, a strong focus was developed to three possible trolleybus solutions to be adopted along the Brignole-Prato section (Val Bisagno) for which an economic feasibility assessment was structured by applying the CBA technique according to the two approaches (financial and economic) indicated by MIT Guidelines (Ministero Infrastrutture e Trasporti, 2014).

The conclusions reached by the authors - and which are briefly summarized here - outline two kinds of considerations. The former relates more to the characteristics of the applied evaluation technique; the latter proposes a general reflection on the use of the CBA method in decisions concerning public investments of collective works in urban contexts.

Regarding the first focus, the application of the technique highlights a set of critical issues: the first is related to the evaluation of the external (collective) effects of the solutions and their economic quantification; some aspects and factors that influence the calculation (such as health or time) not being subjected to commercial exchange, do not have a value (price) explicitly indicated by the market and this must therefore be determined through the application of methodologies indicated by the literature (opportunity cost and willingness to pay); however, the economic values thus quantified cannot be compared with the market prices used for other types of costs and benefits, as they are distorted by external and subjective factors (Sullivan et al., 2006).

For this reason, the corresponding "shadow price" is determined for the different market prices through the application of specific coefficients; however, this operation is, by its very nature, complex and may not adequately reflects the real collective costs and benefits induced.

A second criticality can be attributed to the complexity of the transport projects to be assessed; they bring into play decisions and forecasts that affect not only the considered lanes, but also others connected to it; in the case in question, some modifications to the transport service relating to the means that connect the hilly inhabited areas were considered, with the modification of some routes and the suppression of some lines. This makes the definition of the overall framework of costs and benefits to be considered in the CBA model more complex and the results of the economic and financial sustainability indicators more uncertain.

At this point, the method begins to show the first uncertainties, due precisely to its declination in this specific field of application: it is clear that the evidence of the overall sustainability of the work depends on "who" bears the cost and "who" derives the benefits. It is evident that, even if the planning and management of the projects is delegated to the public administration (also through the LPT manager), it is the community that allows them to be implemented through the payment of taxes and that enjoys the consequent benefits. For this reason, the correct attitude would lie in adopting the latter's point of view. Moreover, it is known that the method offers the greatest advantages when it is applied in a corporate setting, where investor and beneficiary coincide: in this case, useful elements are obtained for the management that can take its decisions and also the point of view of the analyst is uniquely identified. Nonetheless, it is well established that the benefits deriving from a broad spectrum intervention do not involve the community in a homogeneous way; the alterations related to the distribution of costs and benefits are attributable to two main categories:

- geographical: depending on the size of the project, different groups of people can benefit from the effects due to it. For example, the construction of the protected lane in Val Bisagno will involve all the people who reside, move or work within the basin, but the investment, however, being funded nationally, concerns all citizens in a broader sense;

- social: the distribution of costs and benefits is in most cases uneven. Overall, an operation that is extremely advantageous can cause profound damage to a specific segment of the population: it should be noted that this aspect is not influential in the context of financial analysis, since costs and benefits presuppose a single investor (which if anything proceeds then to the distinction of the costs due, as in the case of MIT and the local transport company).

A third critical element is the forecast of future cost and benefit values; the time range indicated by the MIT Guidelines (25 years) needed to insert adjustment factors linked to inflation over time, the forecast of which is very critical as it is linked to the situation of a multiplicity of economic factors.

Furthermore, what emerges from the application is that there is not always a solution that presents, compared to the others, the best indicators of sustainability both according to the economic and financial approach.

This means that the choice of the solution must be made by the investor taking into account not only the collective benefits generated but also the financial conditions necessary for feasibility; for investment projects involving public transport, the revenues deriving from the payment of tickets by users cover only a part of the fixed and variable costs of the service, and which, therefore, is always made a substantial public economic contribution is necessary.

In fact, in the study, the sensitivity analysis to risk appears not secondary: if the initial purpose is to cover the risk even in the case of negative contingencies, it is clear that the rising costs could greatly affect the creation of advantages brought by the infrastructure, but would shift the debate, therefore, on the return on investment as a priority factor and no longer on the utility of the work (thus denying its premises). Consider, for example, the performance of the energy market which is a highly connected variable to the investment in question: the sensitivity could be such as to deny the sustainability of the work itself, despite, all the more so for the purpose of transport sustainability, it would be needed.

Consequently, the second set of conclusive considerations, which mainly concerns the use of the CBA method as a technique indicated by MIT to evaluate - as already mentioned - which solution 
Table 9 - Variations in the values of the inputs and corresponding variations in the output (FNPV)

\begin{tabular}{|c|c|c|c|c|c|c|}
\hline \multirow[b]{2}{*}{ Variable } & \multicolumn{3}{|c|}{ Base value of FNPV: 0,11 millions of $€$} & \multicolumn{3}{|c|}{ Input changes } \\
\hline & $\begin{array}{l}\text { Disadvantage } \\
\text { of the output }\end{array}$ & $\begin{array}{l}\text { Vantage of } \\
\text { the output }\end{array}$ & $\begin{array}{l}\text { Effective } \\
\text { range }\end{array}$ & Min input value & Max input value & $\begin{array}{l}\text { Base value } \\
\text { input }\end{array}$ \\
\hline E19: Purchase of vehicles & 11.3413 & -11.1239 & 22.47 & $26,937,600 €$ & $40,406,400 €$ & $33,672,000 €$ \\
\hline E78: Passive interests & 2.7137 & -2.9954 & 5.71 & $4 \%$ & $6 \%$ & $5 \%$ \\
\hline $\begin{array}{l}\text { E24: Replacement of valley floor } \\
\text { lines }\end{array}$ & 2.8553 & -2.6379 & 5.49 & $24,692,800 €$ & $37,039,200 €$ & $30,866,000 €$ \\
\hline E14: Plant engineering works & 2.4447 & -2.2274 & 4.67 & $5,602,240 €$ & $8,403,360 €$ & $7,002,800 €$ \\
\hline E2: Financial discount rate & 2.5138 & -1.9635 & 4.48 & $3 \%$ & $5 \%$ & $4 \%$ \\
\hline E25: Battery replacement & 1.1025 & -0.8851 & 1.99 & $5,368,000 €$ & $8,052,000 €$ & $6,710,000 €$ \\
\hline E66: Annual revenues & -0.7906 & 1.0079 & 1.80 & $214,858 €$ & $322,287 €$ & $268,572 €$ \\
\hline $\begin{array}{l}\text { E28: Replacement of charging } \\
\text { stations }\end{array}$ & 0.5581 & -0.3408 & 0.90 & $4,040,640 €$ & $6,060,960 €$ & $5,050,800 €$ \\
\hline
\end{tabular}

presents the best relationship between benefits and costs and to quantify the public economic contribution that it is necessary for the economic feasibility of the investment.

What is perplexing is that this instrument is proposed for the allocation of funds for the modernization of the transport system of metropolitan areas (already in a state of alert due to serial environmental problems) in competition between them: it follows that, from a ministerial perspective, a proposed intervention must maximize the investment in comparison with another.
But the CBA tool, as amply demonstrated in this case, does not detect major differences in terms of financial sustainability for the three solutions, while the difference in the results obtained between the two analyzes (financial and economic) are considerable, precisely because of the high contribution of the environmental and social benefits derived from transport solutions, or by putting in place a more comprehensive assessment of the value of the work. Because of these critical issues, recent applications have experimented with the application of CBA combined with other evaluation techniques (such as

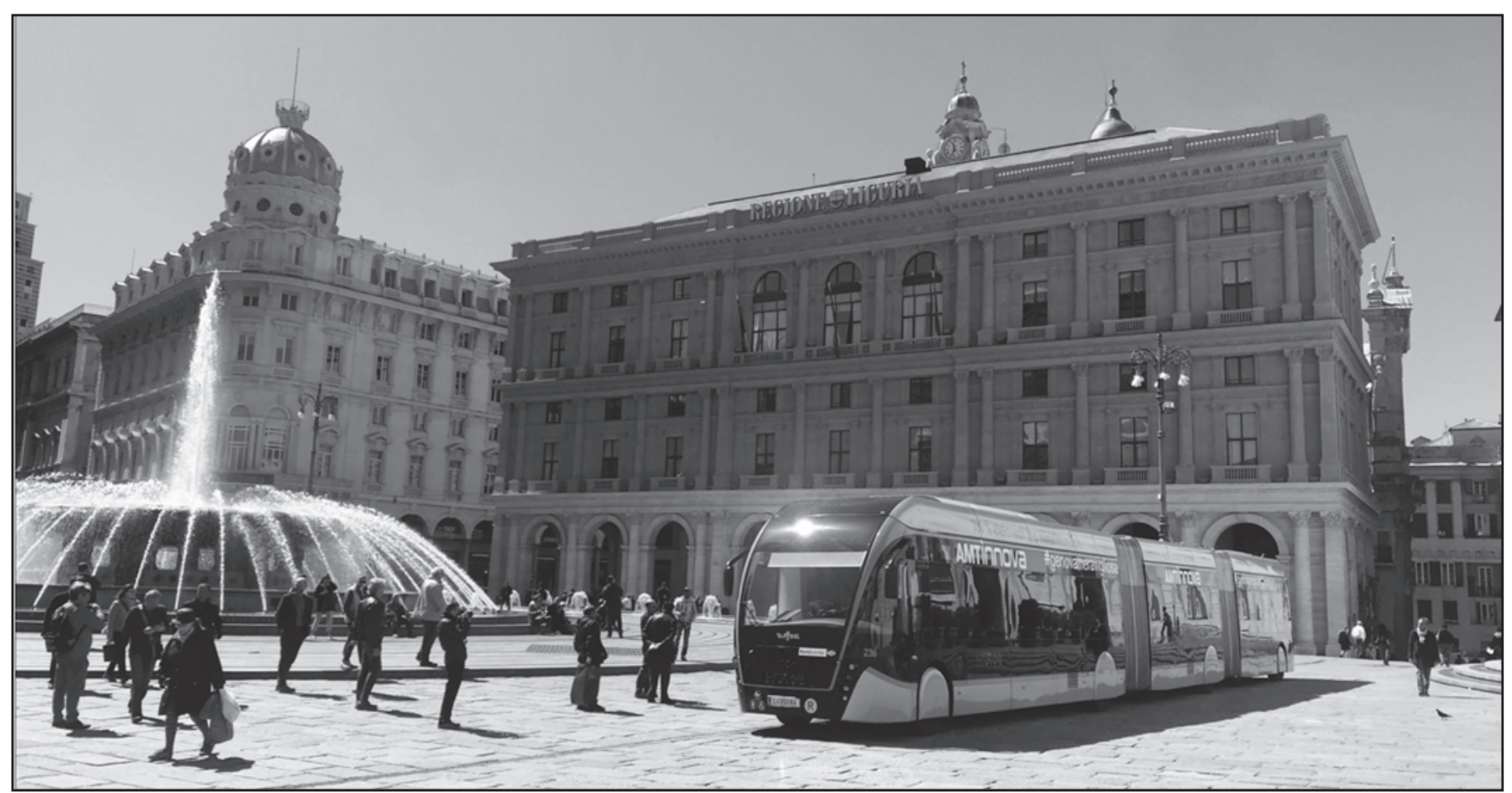

Figure 9 - The three-box trolleybus (24 m.) during the test carried out in Genoa on 6 May 2019. 
multi-criteria analysis or Cost effectiveness analysis) to also take into account the qualitative aspects of transport solutions (Tudela, Akiki and Cisternas, 2006; Guhnemann, Laird and Pearman, 2012).

It is clear from the results how important it is to insert these elements into the evaluation, but they are not actually discriminating from the point of view of the overall amount which, in the three solutions, does not very much. The CBA therefore proves to be suitable and effective in calculating the total investment for the request for assistance, but not for the analysis of transport choices that appear almost indifferent.

What authors want to emphasize is that the space attributed to the choice must consist of a balance between the social effects induced and the financial sustainability of the intervention.

In the context of public investments, for which one of the main purposes is to operate to reduce economic inequalities - through the achievement of the well- being of disadvantaged groups -, the cost-benefit analysis could lead to the adoption of general solutions and that they do not highlight the discretionary aspect among the alternatives, as they are not consciously assumed as possible pertinent answers to the problems of the examined context.

These reflections appear to be of great relevance today in the aftermath of the allocation of European funding for the so-called National Recovery Plans, in the context of which funds are assigned for the construction of works, considered as priorities for the relaunch of the country in the post- pandemic. It is clear that if a broader culture will not be affirmed in the evaluation of "public works" (according to a term that is perhaps obsolete, but which aggregates multiple aspects: urban planning, construction, environment), the considerations that support the feasibility of this or that intervention may be partial or a priori, because they do not appear as the result of an adequate methodological sounding.

Note

This work was developed as part of the thesis "The transformations of urban mobility" (candidates: Andrea Marcenaro and Giulio Minuto; supervisors: professors Ilaria Delponte, Paolo Rosasco; co-supervisor: Ing. Riccardo Genova - Master's Degree in Building Engineering -Architecture, University of Genoa - Polytechnic School). The responsibility for what is reported in this work lies solely with the authors.

* Ilaria Delponte, Department of Civil, Chemical and Environmental Engineering (DICCA) - Polytechnic School - University of Genoa e-mail: ilaria.delponte@unige.it

** Paolo Rosasco, Department of Architecture and Design (DAD) - Polytechnic School - University of Genoa e-mail: paolo.rosasco@unige.it

\section{Authors contributed}

Ilaria Delponte edited paragraphs 1, 2 and 3; Paolo Rosasco edited paragraphs 4, 5 and 6: Paragraph 7 was jointly edited by the authors.

\section{Bibliography}

BANISTER D., The sustainable mobility paradigm, Transport Policy, Vol 15, No 2, 2008, pp. 73-80.

COMUNitÀ EUROPEA, Direttiva 2014/94/Ue del parlamento europeo e del consiglio del 22 ottobre 2014 sulla realizzazione di un'infrastruttura per i combustibili alternativi, 2014.

Città Metropolitana di Genova, Piano Urbano della Mobilità sostenibile della Città Metropolitana di Genova (PUMS), Città Metropolitana di Genova, 2019 (documento scaricabile all'indirizzo internet: https://pums.cittametro politana.genova.it/content/il-pums-di-genovametropoli). COMUNE DI GENOVA, Piano Urbano della Mobilità genovese - Documento finale, Comune di Genova, 2010 (documento scaricabile all'indirizzo internet: http://ww w.mobilitypoint.it/Data/Sites/1/media/pdf/pum/pum.pdf.).

Comune di Genova, Annuario statistico - Edizione 2018, Comune di Genova, 2019.

COSTA Á., The organisation of urban public transport systems in Western European metropolitan areas. Transport Research Part A: Policy Practice, Vol. 30, No 5, 1996, pp. 349-359.

DelPONTE I., "Transport, Ict and the City. Why are Cities interested in Ict?", In Papa R. (a cura di), Towards Smart City. A scientific approach, 2014, pp.17-26.

DISNEY J., Competing through quality in transport services, Managing Service Quality: An International Journal, Vol. 8, No 2, 1998, pp. 112-118. 
VAN EGMOND P.W., NiJKamp P., Vindigni G., A comparative analysis of the performance of urban public transport systems in Europe. International Social Science Journal, Vol. 55, No 176, 2003, pp. 235-247.

ENERGy AND Strategy Group, E-mobility report, E-Book, 2018. EUROPEAN HOUSE-AMBROSETTI, II futuro della mobilità urbana - integrazione e nuovi modelli di gestione nel caso italiano, 2017.

European Comission, Guide to Cost-Benefit Analysis of Investment Projects, 2014.

Gal-Tzur A., Grant-Muller S.M., Kuflik T., Minkov E., NOCERA S., SHOOR I., The potential of social media in delivering transport policy goals. Transport Policy, Vol. 32, 2014, pp. 115-123.

Gibbons S., LyytikÄInen T., Overman H.G., SANChis-Guarner R., New road infrastructure: The effects on firms, Journal of Urban Economics, Vol. 110, 2019, pp. 35-50.

Godinho P., 1 JoAna Dias J., Cost-Benefit Analysis and the Optimal Timing of Road Infrastructures, Journal of Infrastructure Systems, December, 2012.

GonzAlez-Feliu J., Costs and benefits of railway urban logistics: a prospective social cost benefit analysis, https//halshs.archives-ouvertes.fr/halshs-01056135.

Guhnemann A., Laird J.J., PeARMAn A.D., Combining costbenefit and multi-criteria analysis to prioritise a national road infrastructure programme, Transport Policy, Volume 23, pp. 15-24, September 2012.

GWILliam K.M., Cities on the move: a World Bank urban transport strategy review, World Bank Publications, Washington DC, 2002.

Harford J.D., Congestion, pollution, and benefit-to-cost ratios of US public transit systems, Transportation Research Part D, Vol. 11, 2006, pp. 45-58.

HARRIS I., WANG Y., WANG H., ICT in multimodal transport and technological trends: Unleashing potential for the future, International Journal of Production Economics, Vol. 159, 2015, pp. 88-103.

HAJDUK S., The smartness profile of selected European cities in urban management - A comparison analysis, Journal of Business Economics and Management, Vol. 19, No 6, 2018, pp. 797-812.

HOLMGREN J., The efficiency of public transport operationsAn evaluation using stochastic frontier analysis, Research in Transportation Economics, Vol. 39, No 1, 2013, pp. 50-57.

HyARD A., Cost-benefit analysis according to Sen: An application in the evaluation of transport infrastructures in France, Transportation Research Part A, Policy And Practice, Vol. 46, No 4, 2012, pp. 707-719.

INFRAS, External costs of transport - Updated study - Final report, University of Karlsruhe, 2004.

ISPRA, Qualità dell'ambiente urbano. Focus su mobilità pedonale in città, 2017 (documento scaricabile all'indirizzo internet: https://www.isprambiente.gov.it/it /pubblicazioni/stato-dellambiente/qualita-dellambiente- urbano-xiii-rapporto.-focus-su-mobilita-pedonale-incitta.

Malecki E. J., Veldhoen M. E. Network activities, information and competitiveness in small firms. Geografiska Annaler: Series B, Human Geography, Vol. 75, No 3, 1993, pp. 131-147.

MCLEOD S., SCHEURER, J., CURTIS C., Urban public transport: planning principles and emerging practice, Journal of Planning Literature, Vol. 32, No 3, 2017, pp. 223-239.

Margorínová M., Trojanová M., Cost Benefit Analysis: Bypass of Prešov city, MATEC Web of Conferences 117, 00116, DOI: 10.1051/matecconf/20171170011 XXVI R-S-P Seminar, theoretical foundation of civil engineering, 2017. Ministero Infrastrutture e Trasporti (Mit)a, Decreto 4 agosto 2017 - Individuazione delle linee guida per i piani urbani di mobilità sostenibile, ai sensi dell'articolo 3, comma 7, del Dlgs del 16 dicembre 2016 n. 257.

Ministero Infrastrutture e Trasporti (Mit)b, Linee Guida per la valutazione degli investimenti in opere pubbliche nei settori di competenza del Ministero delle Infrastrutture e dei Trasporti, 2017 (documento scaricabile all'indirizzo internet: https://www.mit.gov.it/normativa /decreto-ministeriale-numero-300-del-16062017.

Ministero Infrastrutture E Trasporti (Mit), Piano Nazionale Infrastrutturale per la Ricarica dei veicoli alimentati ad Energia elettrica, 2012.

Ministero Dello Sviluppo Economico (MISE), Piano Nazionale Integrato per I'Energia e Clima 2030, 2020.

Mugion R. G., Toni, M., Raharjo, H., Di Pietro, L., \& Sebathu, S. P., Does the service quality of urban public transport enhance sustainable mobility? Journal of Cleaner Production, Vol. 174, 2018, pp. 1566-1587.

Nuti F., L'analisi costi-benefici, Società Editrice il Mulino, Bologna, 2017.

Pflieger G., Kaufmann V., Pattaroni L., Jemelin C., How does urban public transport change cities? Correlations between past and present transport and urban planning policies, Urban Studies, Vol. 46, No 7, 2009, pp. 1421-1437. RoY W., YvRANDE-Billon A., Ownership, contractual practices and technical efficiency: The case of urban public transport in France, Journal of Transport Economics and Policy, 2007, Vol. 41, No 2, 2007, pp. 257-282.

Schwanen T., lucas K., Akyelken N., Solsona D. C., Carrasco J. A., NeUtens T., Rethinking the links between social exclusion and transport disadvantage through the lens of social capital, Transportation Research Part A: Policy and Practice, Vol. 74, 2015, pp. 123-135.

SHEFER D., HAVIRAM H., Incorporating agglomeration economies in transport cost-benefit analysis: The case of the proposed light-rail transit in the Tel-Aviv metropolitan area, Regional science, 2005.

Standing C., Standing S., Biermann, S., The implications of the sharing economy for transport, Transport Reviews, Vol. 39, No 2, 2019, pp. 226-242. 
Sullivan W.G., Wicks E.M., LuxhOJ J.T., Economia applicata all'ingegneria, Pearson Education Italia, 2006.

Tudela A., Akiki N., Cisternas R., Comparing the output of cost benefit and multi-criteria analysis an application to urban transport investments, Transportation Research Part A, Vol. 40, 2006, pp. 414-423.

\section{Internet references}

Automobile Club d'Italia, www.aci.it Istituto Nazionale di Statistica (ISTAT), www.istat.it. Ministero Infrastrutture e Trasporti, www.mit.gov.it 



\title{
Mobilità sostenibile e sostenibilità
} economica: il caso della nuova linea filoviaria a Genova

Ilaria Delponte*, Paolo Rosasco** parola chiave: mobilità urbana, linea filoviaria, analisi costi-benefici

\begin{abstract}
Con oltre 3,5 miliardi di persone che risiedono attualmente nelle grandi città del mondo, il tema della mobilità urbana è una questione attuale ed è particolarmente importante nei paesi europei dove nelle aree urbane si concentra oltre il 75\% della popolazione. Ancora oggi, molti degli spostamenti quotidiani dipendono dalle auto e da altri veicoli motorizzati privati, con un forte impatto in termini di inquinamento atmosferico, sonoro e sul cambiamento climatico visto che nell'Unione europea $i$ trasporti sono responsabili di un quarto delle emissioni di gas serra. Ridurre il trasporto privato e rendere $i$ sistemi di trasporto urbani più ecologici e più efficienti presenta quindi dei vantaggi importanti: per la salute, il clima e la prosperità delle città. Nuovi modelli di trasporto e di accessibilità urbana, sempre più orientati verso la sostenibilità ambientale, devono quindi essere adottati; la scelta della soluzione trasportistica deve essere fatta in relazione alla fattibilità non solo tecnica ma anche economica, sociale ed ambientale.

Prendendo spunto dal Bando emesso nel 2018 dal Ministero delle Infrastrutture e dei Trasporti per la selezione delle proposte di mobilità urbana che possono

accedere alle risorse economiche destinate al potenziamento e alla realizzazione di sistemi di trasporto rapido di massa previste dalla Legge $n$. 232/2016, il presente contributo tratta della valutazione di tre proposte trasportistiche ipotizzate per il collegamento tra il centro della città di Genova (Stazione Brignole) e il quartiere di Prato, lungo la Val Bisagno, sviluppate secondo le indicazioni contenute nel Piano Urbano di Mobilità del Comune.

In particolare è sviluppata l'Analisi Costi-Benefici $(A C B)$ secondo le indicazioni riportate nel Bando e nelle Linee Guida del Ministero delle Infrastrutture e Trasporti per la valutazione degli investimenti in opere pubbliche. L'obiettivo è quello di verificare l'applicabilità dello strumento dell'ACB per la valutazione della sostenibilità economica e finanziaria delle soluzioni analizzate anche in relazione alle indicazioni riportate nella normativa, agli scenari trasportistici configurati e all'attendibilità dei risultati ottenuti, ai fini della scelta della soluzione trasportistica da adottare.
\end{abstract}




\section{INTRODUZIONE}

In un momento di crescente preoccupazione per il riscaldamento globale e altri problemi ambientali, un maggiore utilizzo dei trasporti pubblici locali è spesso proposto come contributo essenziale di una soluzione complessa (Holmgren, 2013; Mugion et al., 2018).

Nonostante, per molto tempo, questo argomento sia stato avvertito come un tema di nicchia, oggi ci si mostra tutti universalmente interessati ad un servizio efficiente ed affidabile, grazie ad una più acuta percezione della portata sociale e culturale che il trasporto collettivo detiene nella sfera degli interessi del cittadino.

È interessante chiedersi il perché di questo cambiamento di paradigma (Banister, 2008; McLeod et al., 2017).

Le citta contemporanee, in ambito italiano più che in ogni altra realtà, sono frutto di molteplici stratificazioni avvenute in secoli di storia che hanno trasformato i vivaci borghi medioevali in caotiche, e spesso disordinate, citta metropolitane. In continua mutazione, esse cambiano in base alle trasformazioni economiche e sociali che coinvolgono la società. Ognuna pero secondo processi e dinamiche estremamente variabili e diversificate, in base alle singolarità del contesto (Van Egmond et al., 2003; Pflieger et al. 2009).

Come noto, il processo di industrializzazione e ricostruzione, iniziato nel dopoguerra, ha originato radicali cambiamenti nell'assetto urbano e produttivo di molte citta occidentali. Tali mutazioni avvenute velocemente, spesso senza un'adeguata pianificazione, hanno dato vita a gravi problemi riguardanti fruibilita e salubrita delle aree urbane. La sensibilizzazione nei confronti di tali tematiche ha portato negli ultimi decenni a mettere in atto politiche di adeguamento delle grandi metropoli europee (Costa, 1996; Gwilliam, 2002).

Alle grandi mutazioni dell'assetto urbano si accompagna un adeguamento dell'apparato infrastrutturale, necessario affinche gli spostamenti possano avvenire in maniera veloce, sicura ed efficiente, pena il declino della citta stessa e l'abbandono da parte dei suoi cittadini.

Ciò che emerge, infatti, è che uno dei fattori cruciali tra le città che vogliono competere a livello internazionale è I'efficienza del sistema di trasporto pubblico (Disney, 1998, Roy e Yvrande-Billon, 2007, Hayduk, 2018). Il servizio organizzato per la collettività, improntato su criteri di efficienza, affidabilità e inclusività garantisce equità al trattamento dei cittadini e concorre ad un'immagine positiva della città. Nel 2015, I'Istituto per la Ricerca Sociale ha analizzato quelle buone prassi che contribuiscono al miglioramento dell'accessibilità del trasporto pubblico, per rafforzare da parte dell'UE la promozione dell'integrazione delle problematiche dell'inclusione sociale nelle politiche di trasporto pubblico. Tali approcci mirano, inoltre, alla tutela dell'ambiente, cercando di spostare gli utenti verso il trasporto collettivo e di promuovere sistemi di trazione meno inquinanti. La pianificazione di sistemi e infrastrutture sostenibili rende infatti le citta attrattive, favorisce gli investimenti e la creazione di imprese e di lavoro (Malecki e Veldhoen, 1993; Delponte, 2014; Gibbons et al., 2019). Da questo quadro si evince come, per il Trasporto Pubblico Locale (TPL), si prefiguri un rilancio sotto ogni aspetto: economico, sociale ed ambientale.

In conseguenza di tale rinnovato interesse, la sfida che è stata lanciata è rivolta alla capacita delle autorità pubbliche di trovare soluzioni innovative per i servizi di trasporto, attivando e coordinando operatori diversi su vari livelli per fornire servizi di trasporto integrati e flessibili capaci di raggiungere destinazioni diverse e di permettere ad utenti di varie categorie di organizzare sia viaggi brevi sia lunghe percorrenze.

Uno studio presentato all'European House-Ambrosetti del 2017 stima che le citta metropolitane italiane, allineando il trasporto collettivo alle migliori pratiche europee, "potrebbero generare un beneficio economico di 10/12 miliardi di euro all'anno, fra decongestionamento, risparmi di tempo, riduzione degli incidenti e dell'inquinamento atmosferico, acustico e climatico" (European House-Ambrosetti, 2017).

Proprio in relazione al tema della mobilità sostenibile, il presente contributo tratta della verifica della fattibilità economica di un progetto relativo ad una nuova linea filoviaria a Genova; il lavoro è così strutturato: nel paragrafo 2 è delineato sinteticamente il contesto urbano preso a riferimento nello studio (Val Bisagno) e gli strumenti di pianificazione previsti dall'Amministrazione Comunale a supporto dei progetti di mobilità; nel paragrafo 3 sono descritte tre possibili soluzioni trasportistiche da adottare per il trasporto pubblico lungo la Val Bisagno e le relative caratteristiche tecniche.

I paragrafi 4 e 5 sono invece dedicati alla valutazione finanziaria ed economica delle tre soluzioni trasportistiche attraverso I'applicazione della tecnica dell'Analisi Costi-Benefici (ACB) con i relativi risultati riportati nel paragrafo 6.

Il paragrafo 7 riporta la verifica della sensitività delle variabili di input inserite nel modello di ACB e l'applicazione dell'Analisi di Monte Carlo per la verifica probabilistica dei risultati ottenuti. Nelle conclusioni del paragrafo 8 alcune riflessioni critiche vengono riportate in merito alI'applicabilità della tecnica per la valutazione delle proposte progettuali per la nuova linea filoviaria della Val Bisagno, al processo e ai metodi impiegati, che possono essere comuni e replicabili in altri casi similari.

\section{LA MOBILITÀ URBANA E GLI STRUMENTI DI PIANIFICAZIONE: IL CASO STUDIO DI GENOVA}

Per inquadrare gli interventi di mobilità sostenibile che sono stati pianificati recentemente a Genova è necessaria una contestualizzazione territoriale e normativa che, da un lato, mostri le ragioni delle trasformazioni opzionate dal capoluogo ligure e, dall'altro, permetta di cogliere al 
meglio come la Superba si inserisce come test-bed all'interno delle recenti evoluzioni legislative.

La peculiarità di questo territorio e dovuto in primo luogo al fatto che, differentemente dalle grandi città italiane ed europee, la maggior parte della popolazione residente di tutta l'area metropolitana si concentra nel capoluogo: circa il $69 \%$ della popolazione risiede entro i confini del Comune di Genova. E un territorio per un verso densamente popolato, ma soltanto per il $30 \%$ antropizzato: tutto il resto della superficie territoriale comunale non è agibile ed è coperta da vegetazione di cornice ed è caratterizzata da elevate pendenze.

E inutile soffermarsi sull'unicità morfologica che caratterizza la citta: la sua complessa struttura viaria, risultante da scelte insediative ingiustificate, non sempre lascia trasparire le potenzialità che racchiude. Ed e proprio questa complessità che forza il sistema di mobilita urbano ad essere estremamente diversificato. Al fine di soddisfare la domanda dei passeggeri, il servizio TPL dispone di bus, filobus, ascensori verticali e orizzontali, funicolari, cremagliere, metropolitana e trasporto marino.

Le strade e le infrastrutture presenti sul territorio sono spesso esigue e inadeguate, le carreggiate sono quasi sempre a una corsia per senso di marcia e spesso i sensi unici portano l'utente a fare un percorso differente tra andata e ritorno durante i suoi spostamenti. La complessità e aumentata dal fatto che le strade si inerpicano verso le alture e la carenza di spazi non permette ampi margini di manovra.

Questi fattori incidono sensibilmente sul modo di muoversi all'interno della citta. Infatti i dati riportati sul Comune di Genova mostrano come il tasso dell'utilizzo del TPL da parte dei residenti sia del $32 \%$, percentuale piuttosto alta per lo scenario italiano ed inoltre la quota parte di spostamenti interni non motorizzati, ossia a piedi o in bici, e del $23,8 \%$, dato estremamente alto per una citta non propriamente piana, terzi solo dopo Torino (32\%) e Bologna $(28,2 \%)$ nelle quali il contributo e dato dalle biciclette, non dall'utenza pedonale.

La realtà genovese è singolare anche in rapporto alla struttura demografica ed alle dinamiche di trasformazione; la popolazione residente sta invecchiando e contraendo sensibilmente.

L'indice di vecchiaia, ovvero il rapporto tra la popolazione di età superiore a 64 anni e quella di età inferiore a 15 anni, è maggiore $(2,4)$ rispetto alla media ponderata delle 14 Città Metropolitane italiane (pari a 1,5) (Comune di Genova, 2019). Il trend della popolazione evidenzia un marcato declino: dal 1981 ad oggi i residenti sono calati di circa 200 mila unità, in controtendenza rispetto a quanto si rileva nelle maggiori città italiane. Questa particolarità porta con sé inevitabili considerazioni e differenze che si riflettono sullo scenario genovese della mobilita e dei rapporti sociali che intrinsecamente sono presenti in ambito urbano.

Per quanto riguarda il parco veicolare, i dati forniti dall'Automobile Club d'Italia (ACI), evidenziano che le autovetture circolanti nella Città Metropolitana di Genova e pari a 421 mila nel 2017 (anno di indagine per il Piano della Mobilità, come specificato in seguito), in lieve flessione rispetto al passato, ma nel solo capoluogo, invece, ne circolano 270 mila, pari a circa il $65 \%$ del totale.

Tuttavia, dato emblematico per Genova e la densità di autovetture (parco auto per 1.000 abitanti) pari a 492,94, la più bassa rispetto alle altre citta metropolitane. Parlando in termini di valore assoluto il parco auto di Genova e piuttosto contenuto; valori inferiori sono presenti a Cagliari, Messina e Reggio Calabria (ISPRA, 2017). All'interno di questa rappresentazione a tinte ben marcate della situazione della mobilità attuale, si inserisce tuttavia il qua-

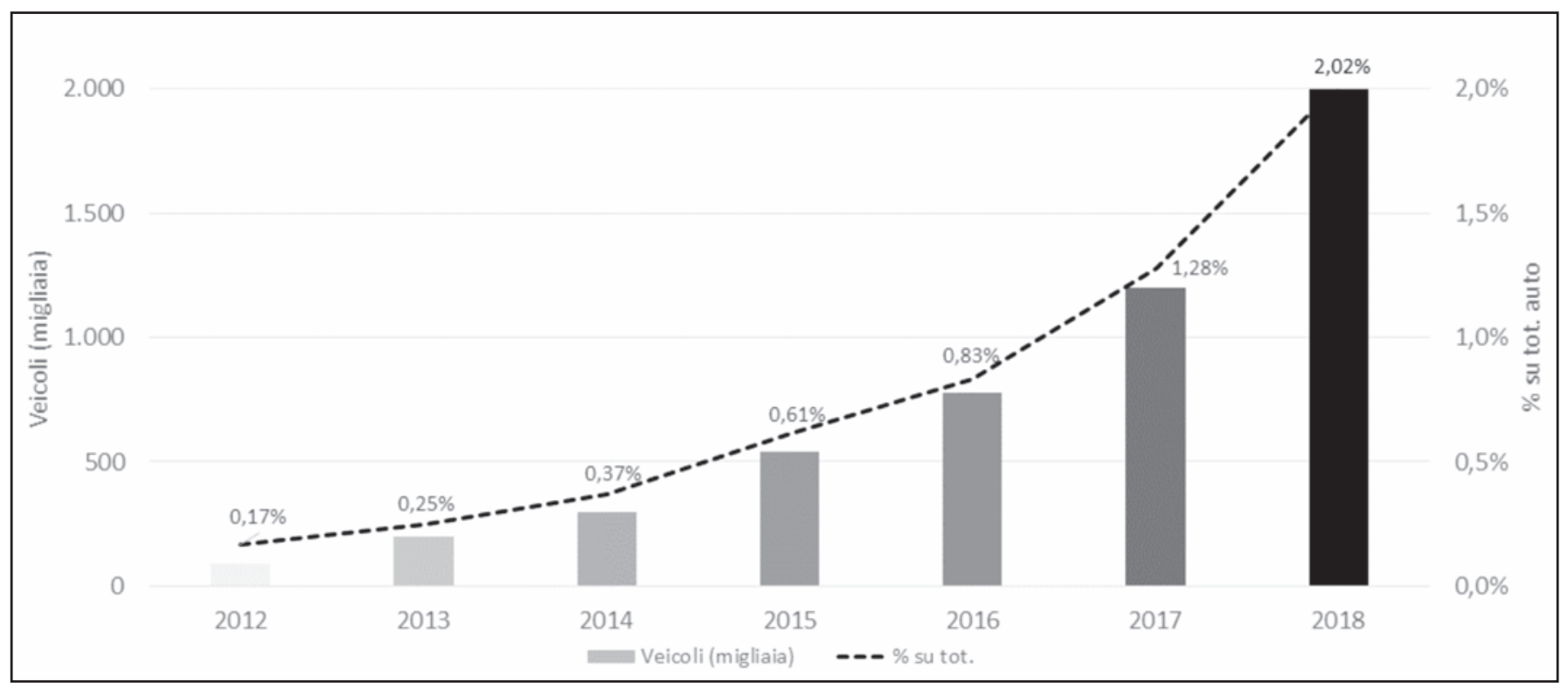

Figura 1 - Vendite globali di auto elettriche e percentuale su totale delle auto vendute. 
dro estremamente magmatico delle tendenze che stanno impattando i trasporti a scala globale.

L'introduzione di tecnologie cosiddette "disruptive" sta conducendo verso grandi cambiamenti nel mondo dei trasporti, secondo una prospettiva di maggiore efficienza e sicurezza.

Questi pongono le realtà metropolitane di fronte ad una sfida di grande portata, ossia individuare le modalità attraverso le quali gestire e trarre vantaggio da tali tecnologie innovative, al fine di risolvere le maggiori problematiche che affliggono tali contesti (inquinamento e congestione, considerati in primis tra le esternalità negative). Si candidano ad assolvere questo compito, le piattaforme digitali dalle quali accedere e pagare una gamma di servizi di trasporto su richiesta; mediante tale sistema innovativo unificato (chiamato diffusamente MAAS, Mobility As A Service) e possibile offrire ai singoli individui un accesso simultaneo ai differenti servizi di trasporto: da tram e autobus a taxi e bike sharing (Standing et al., 2019).

L'innovazione tecnologica sta introducendo nel settore della mobilita anche il paradigma dell'interconnessione; iniziano infatti ad essere presenti sul mercato veicoli in grado di scambiare informazioni con altri dispositivi che si trovano in prossimità (Gal-Tzur et al., 2014; Harris et al., 2015; Schwanen, 2015).

Questa tecnologia e già largamente sviluppata ed andrà a sostegno delle diverse fasi che dovrebbero portare al veicolo autonomo, in quanto prodotto degli avanzamenti compiuti.

All'interno di cambiamenti di tale entità, la trazione elettrica e una delle tecnologie maggiormente promettenti, in grado di migliorare la qualità di vita nei contesti metropolitani, ridurre le emissioni che alterano il clima e la dipendenza dai combustibili fossili.

Nell'ultimo lustro, il comparto elettrico ha visto un'espansione significativa della domanda (Fig. 1 - Energy and Strategy Group, 2018).

Il cambiamento di paradigma in Italia non è per ora così tempestivo: alla chiusura del 2018, con 14.000 macchine elettriche in uso, la penisola si colloca tra i fanalini di coda d'Europa, anche se i provider tecnologici si stanno attrezzando per rispondere alla domanda e la tendenza a promuovere la mobilita elettrica in aree urbane e condivisa dai soggetti regolatori che hanno previsto anche piani di finanziamento. A riguardo, si citano, a titolo esemplificativo, le iniziative ministeriali del Piano Nazionale Infrastrutturale per la Ricarica dei veicoli alimentati ad Energia elettrica (PNire) (Ministero Infrastrutture e Trasporti, 2012) - e del Piano Nazionale Integrato per I'Energia e Clima 2030 (PNIEC) (Ministero Sviluppo Economico, 2020). II passaggio all'elettrico nel campo del trasporto pubblico risulta già in atto parzialmente.

La maggior parte delle grandi realtà metropolitane hanno infatti necessita di svecchiare il parco dei mezzi TPL, e di scegliere veicoli che siano sempre più green: la conversione all'elettrico viene quindi a far parte degli ordinari piani di investimento delle aziende. Inoltre, concordemente alla Direttiva Europea 2014/94 sui combustibili alternativi (Comunità Europea, 2014), I'azione coordinata a livello nazionale coinvolge oltre all'elettrico, anche altri fuels quali i gas naturale liquefatto e compresso e l'idrogeno. Se l'obiettivo condiviso è quello di mitigare gli effetti dei gas serra e non solo, l'interrogativo che si pone è come fare in modo che tale cambiamento culturale avvenga con l'inclusione di tutti e contribuisca ad una accresciuta competitività del sistema trasporti e del Paese. Consapevole dello stato di fatto dei contesti urbani italiani, di cui Genova è l'emblema, ad agosto del 2017 il Ministero delle Infrastrutture e dei Trasporti (MIT) introduce un nuovo strumento di pianificazione dedicato alle 14 Città Metropolitane italiane, il Piano Urbano della Mobilità Sostenibile (PUMS) (Ministero Infrastrutture e Trasporti, 2017a) avente come obiettivo centrale l'elettrificazione del Trasporto Rapido di Massa (TRM). Sono ammessi a finanziamento, in particolare, tre categorie di opere: Sistemi Ferroviari Metropolitani, Metropolitane e Tram, o comunque interventi infrastrutturali che realizzino un TRM ad emissioni zero. II decreto parte da un assunto: la velocità di percorrenza del TPL metropolitano italiano è circa la metà di quella delle grandi aree metropolitane europee. L'anomalia italiana rispetto agli altri Paesi d'Europa e il marcato sottodimensionamento della rete di mobilita su ferro (treni, tram, metropolitane): in Italia il numero si ferma a 3,8 km per milione di abitanti di rete metropolitana, meta di quella della Germania e un terzo della Spagna. Occorre, quindi secondo il MIT, investire in infrastrutture elettriche che abbiano un tale impatto cittadino da ridurre considerevolmente l'inquinamento gassoso, da permettere un sempre più deciso shift modale verso il trasporto collettivo e da giustificare costi gravosi a lungomedio termine. Le principali aree bersaglio di questa iniziativa sono, come detto, le città metropolitane.

Partendo dal quadro conoscitivo dell'esistente, il PUMS della Città Metropolitana di Genova ${ }^{1}$ argomenta in maniera articolata la proposta di 4 "assi di forza" (principalmente su corsia dedicata) che si dispiegano sul territorio comunale, intercettando gli assi più importanti della mobilità cittadina. Si agisce così sul traporto "di massa", intercettando il maggior numero di utenza su tutto il comprensorio interessato (non solo su una particolare direttrice), e sulla "rapidità" e puntualità assicurando la corsia protetta lungo quasi tutto il tracciato, ponendo il tema di una concreta priorità al TPL nei confronti del trasporto privato. A questo punto, si pone tuttavia la scelta tecnologica

\footnotetext{
${ }^{1}$ Il PUMS è stato approvato con Deliberazione del Consiglio Metropolitano n. 20 del 31 luglio 2019. In rapporto al Piano Strategico della Città Metropolitana di Genova, approvato il 21 aprile 2017, il PUMS costituisce attuazione delle strategie e delle linee di azione, in un orizzonte temporale di medio-lungo periodo, sviluppando una visione di sistema della mobilità urbana nel capoluogo genovese e nell'intera area metropolitana (Città Metropolitana di Genova, 2019).
} 
di come e con cosa attrezzare gli assi di forza: Genova tenta, nell'ambito del PUMS e del conseguente finanziamento richiesto al MIT, il ricorso all'esecuzione di 4 linee filoviarie in sede propria ${ }^{2}$, come intervento infrastrutturale che meglio si abbina alla situazione descritta. L'ipotesi traguardata è quella di conseguire, nel lungo termine, l'immatricolazione dei filobus su tre casse, $24 \mathrm{~m}$. di lunghezza, già presenti in altri paesi d'Europa ma che in Italia, attualmente, non possono circolare.

Il presente studio analizza, per l'asse filoviario della Val Bisagno, tre possibili soluzioni e valuta la loro sostenibilità economica secondo le indicazioni riportate nel Bando del MIT e nella normativa nazionale relativa a questo tipo di infrastrutture; l'obiettivo è quello di definire, per ciascuna soluzione, le condizioni di fattibilità anche ai fini di individuare quale tra le tre meglio risponde ai requisiti del Bando e possa essere oggetto della proposta di finanziamento da parte del Comune di Genova al MIT.

\section{LA VAL BISAGNO E LA NUOVA LINEA FILOVIARIA}

In considerazione di una serie di iniziative politiche che hanno dato vita anche a legittime aspirazioni da parte della popolazione, la Val Bisagno risulta di gran lunga "I'ambito di intervento" prioritario su cui si concentrano le maggiori attese circa il potenziamento degli assi di trasporto pubblico locale.

La condizione viabilistica della valle, infatti, e fortemente caratterizzata si dalle condizioni morfologiche, ma soprattutto da una fitta maglia insediativa, rispetto alla quale la rete viabilistica risulta assolutamente interstiziale e subordinata. Le sponde del fiume Bisagno sono densamente edificate e costellate da un gran numero di servizi strategici per la citta, che si sono tuttavia stratificati senza un parallelo adeguamento dell'apparato infrastrutturale a supporto. Una crescita incontrollata e speculativa, avvenuta nell'arco degli anni Sessanta e Settanta, ha pregiudicato di molto le scelte future e gli spazi di manovra ad oggi risultano assai limitati. Ne deriva una condizione di particolare criticità, unica tra le macro-aree del capoluogo a non essere servita da mezzi su ferro o linee ad alta capacita, a dispetto dell'ingente numero di spostamenti che vi avvengono.

Risalendo alle origini dell'assetto antropico attuale della valle, si giunge al 1873 con l'annessione dei comuni orientali di Genova alla grande città marinara. L'annessione fu motivata, da un lato, dalla mancanza di spazio all'interno delle mura e la conseguente espansione nella valle (con la realizzazione di alcuni servizi cittadini), e, dall'altro, dalla necessita di ampliare il bacino di riscos-

\footnotetext{
${ }^{2}$ I quattro assi delle filoviarie sono: Centro città-Prà (asse Ponente); Campi-S. Fruttuoso (asse Centro); Piazzale Kennedy (Fiera)-Prato (asse Val Bisagno); Centro-Nervi (asse Levante).
}

sione delle tasse per sopperire alle spese infrastrutturali in programmazione per il capoluogo. II territorio della vallata risente profondamente di tale processo che trasforma il territorio da tipicamente agricolo fino ad assumere i connotati propri delle periferie periurbane. I primi interventi "sintomo" di questo inglobamento possono essere individuati nella costruzione del Cimitero Monumentale di Staglieno, ma anche in un'intensa attività edificatoria che porta all'insediamento di numerosi siti industriali, fonderie e concerie. Con il secondo decreto del 1926 e le conseguenti successive annessioni al Comune di Genova, la valle viene ulteriormente costellata di industrie e servizi di scarsa qualificazione nonché di edilizia economica popolare, configurandosi come vera e propria area urbana di espansione. Ma e principalmente nel secondo dopoguerra (in accordo al PRG del '60) che, sotto la spinta della crescita demografica, Genova riversò la sua fame di spazi edificabili anche lungo il Bisagno. Tale disordinata trasformazione ha chiaramente portato con se conseguenze, spesso negative: dalle più tragiche dovute ai dissesti idrogeologici ai quotidiani disagi legati alla congestione veicolare ed all'accessibilità in sicurezza.

In merito all'introduzione dei servizi di trasporto pubblico a Genova, allo sviluppo industriale della citta e alla sua crescita demografica ed insediativa e conseguita la necessita di adeguare il trasporto pubblico ai crescenti fenomeni di pendolarismo. Nel 1878 viene introdotta in citta la prima tranvia - consistente dapprima in una carrozza su rotaie trainata da cavalli - gestita dalla Compagnia Generale Francese di Tramways, la quale provvede ad una diffusione capillare della rete su ferro che raggiunge la Val Bisagno nel 1890. Nel 1895 migliora il servizio nella valle, estendendosi in piazza Manin-Staglieno, passante per Via Montaldo, fino a San Gottardo e nel 1897 si procede con I'istituzione di un servizio diretto tra piazza De Ferrari e Prato. Nel primo decennio del ' 900 l'Amministrazione Comunale matura l'intenzione di municipalizzare la rete tranviaria - fino ad allora privata - e nel 1913, ancor prima di intraprendere un programma di acquisizioni, avvia la

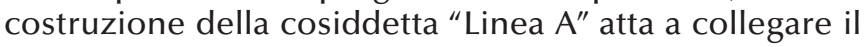
quartiere di Marassi con quello di Quezzi.

La predominanza strategica del "ferro" rimane sostanzialmente indiscussa fino al 1934 anno in cui viene attuata la cosiddetta "riforma tranviaria" che da il via alla progressiva sostituzione del tram, a partire dal centro cittadino, con mezzi su gomma ritenuti preferibili in virtu della maggior flessibilità.

Dai primi bus si passa ai filobus, con la costruzione nel 1938 della rete di alimentazione, a cui segue una vasta diffusione dovuta alle difficolta di approvvigionamento del carburante per gli autobus. La tecnologia viene tuttavia progressivamente dismessa a causa degli ingenti danni subiti dalla rete durante il conflitto mondiale. Inoltre, il rilancio economico del dopoguerra rinnova i paradigmi della mobilita e, di riflesso, le condizioni del traffico cittadino, per cui l'autobus torna ad assumere il ruolo predo- 
minante portando alla cessazione totale del servizio filoviario nel 1973.

L'azienda di trasporto pubblico locale (oggi Azienda Mobilità e Trasporti S.p.A. - AMT) rimuove le linee tranviarie rimaste attive sulle direttrici del traffico cittadino e nel 1966 viene soppressa in Val Bisagno I'ultima tratta ancora attiva.

Tuttavia, anche in seguito a quegli anni, nel Piano Regolatore Generale del Comune di Genova del 1980 vengono confermate due importanti argomentazioni a supporto dell'estensione della linea nella valle: anzitutto, la morfologia del territorio sulle sponde del fiume implica un assetto territoriale ad alta densità abitativa (di circa 300-400 ab. per ettaro) dislocato su una fascia di circa $800 \mathrm{~m}$, con una rete viaria confluente su un'unica (seppur doppia) direttrice stradale di valle.

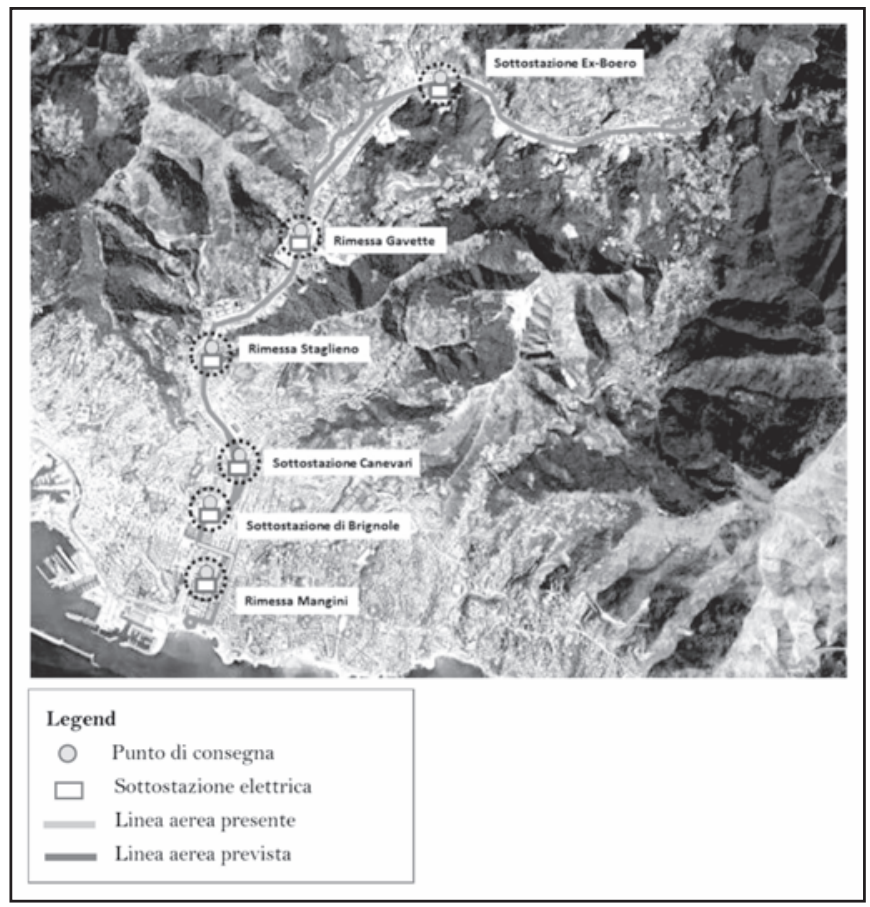

Figura 2 - Linea filoviaria con alimentazione da linea aerea.

Secondariamente, I'importanza di una linea di forza in sede propria, caratterizzata da un'alta attrattività, che viene quindi considerata come soluzione ideale per soddisfare quote significative di domanda. Le prescrizioni del PUMS riprendono e confermano sostanzialmente tale visione originaria e ripropongono l'asse di forza per il trasporto di massa, su sede propria (Città Metropolitana di Genova, 2019).

Tuttavia, la scelta tecnologica sulla tipologia di mezzi impiegati e le caratteristiche degli stessi è stata accompagnata da un ampio dibattito cittadino e da un'attenta valutazione delle diverse soluzioni.

Come noto, i sistemi filoviari si basano sull'utilizzo di veicoli su gomma a propulsione elettrica, i quali vengono alimentati attraverso un'infrastruttura di distribuzione del-
I'energia elettrica chiamata appunto, filovia. Generalmente, la captazione della corrente elettrica avviene attraverso dei conduttori elettrici mediante dispositivi denominati aste filoviarie o aste di captazione.

La rete aerea e composta da un bifilare, ossia un doppio filo appeso tramite un sistema di funi e cavi di tensione che permettono alla linea aerea di rimanere nella posizione assegnata anche sotto lo sforzo del proprio peso o di altre condizioni climatiche come la presenza di vento.

La necessita di avere un bifilare e non un singolo filo, come avviene nei tram o nei treni, deriva da una questione di composizione del sistema del circuito elettrico di alimentazione.

Difatti mezzi come tram o motrici ferroviarie dispongono di un circuito formato, oltre che dalla linea aerea, anche dal binario con il quale sono in contatto metallico tramite le ruote, nel caso di un mezzo di trasporto filoveicolare, questo non e possibile perché la linea non dispone di rotaie.

La linea aerea e posizionata ad una altezza di circa 5-6 metri rispetto alla sede stradale, per non essere d'impedimento alla normale circolazione degli altri veicoli (come, per esempio, camion o mezzi con particolari sporgenze verticali) e per garantire una maggiore sicurezza dell'impianto.

La definizione di filovia, così come e stata introdotta prima, negli ultimi anni sta subendo una trasformazione di concetto, abbandonando lo stretto legame con il termine "filo" verso nuove tecnologie innovative in campo di sostenibilità e salvaguardia dell'ambiente.

Il riferimento normativo è il DM. n. 238 del 10/07/2003 «Disposizioni concernenti le procedure di omologazione dei filoveicoli per il trasporto di persone», il quale rappresenta una serie di norme a cui i nuovi filobus e quelli ancora in uso devono far riferimento e ove mancanti, adeguarsi alla vigente norma.

Le soluzioni tecniche selezionate oggetto del presente studio sono:

1) Linea filoviaria con alimentazione da linea aerea;

2) Linea filoviaria con ricarica a fermata;

3) Linea filoviaria con ricarica a capolinea

La prima soluzione (Fig. 2) consiste di una linea aerea bifilare del tutto simile a quella che attualmente alimenta I'unica linea filobus di Genova (linea 20).

I mezzi previsti sarebbero totalmente elettrici, con una lunghezza pari a 24 metri; la capacità di trasporto è pari a 220 passeggeri a vettura e pari a circa 4000 passeggeri alI'ora. Per garantire la richiesta di domanda nelle ore di punta sarebbero necessari 17 filobus operanti contemporaneamente sulla linea, con una frequenza di circa 4 minuti ${ }^{3}$.

\footnotetext{
${ }^{3}$ Per far fronte ad eventuali guasti o malfunzionamenti è previsto l'acquisto di 20 mezzi.
} 


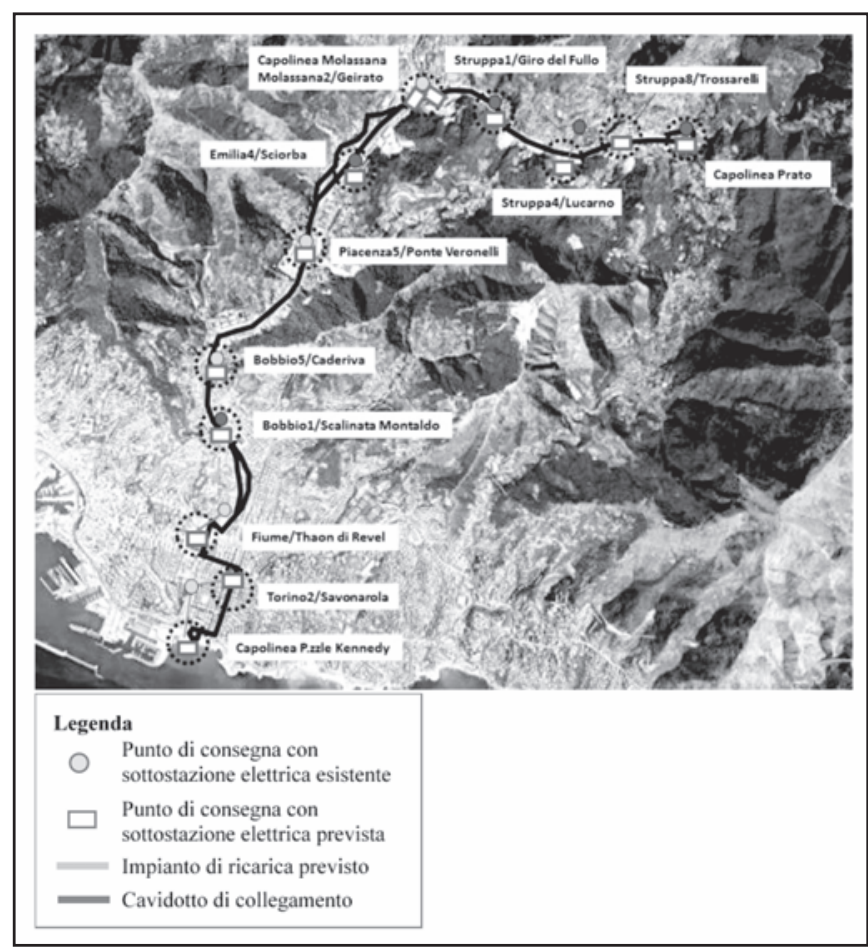

Figura 3 - Linea filoviaria con ricarica a fermata.

I punti di allaccio alla rete elettrica previsti per l'alimentazione della rete sono $6^{4}$.

Ai fini di ridurre i tempi di percorrenza, la soluzione prevede altresì la realizzazione di una serie di modifiche alla sede stradale (quali la realizzazione di cordoli) per permettere una marcia più fluida, senza interruzioni o cambi di corsia.

La seconda e simile a quella precedente, ma concettualmente l'approccio e diverso (Fig. 3). I mezzi impiegati sono anche essi totalmente elettrici ma attingono l'energia in punti predefiniti disposti lungo il percorso (in corrispondenza delle fermate) attraverso sistemi di ricarica istantanea (con tempi nell'ordine dei 20 secondi); il bus è quindi dotato di un quantitativo minimo di batterie, sufficiente a permettergli di effettuare tratte molto limitate (nell'ordine del kilometro). I punti di ricarica delle batterie sono 23, ciascuno collegato ad un punto di consegna dell'energia ( 12 in totale).

La possibilità di utilizzare batterie di ridotte dimensione consente di ridurre il peso del mezzo e di disporre di più spazio per il trasporto dei passeggeri. I mezzi previsti sono di pari lunghezza rispetto alla soluzione precedente (24 m.) ed una capacità di circa 200 passeggeri ciascuno;

\footnotetext{
${ }^{4}$ Essi garantiscono l'approvvigionamento dell'energia necessaria per la movimentazione dei mezzi; comprendono il trasformatore, il raddrizzatore e i necessari sistemi di protezione e sicurezza. Il costo stimato per la realizzazione di ciascun punto è pari a 1,5 milioni di euro.
}

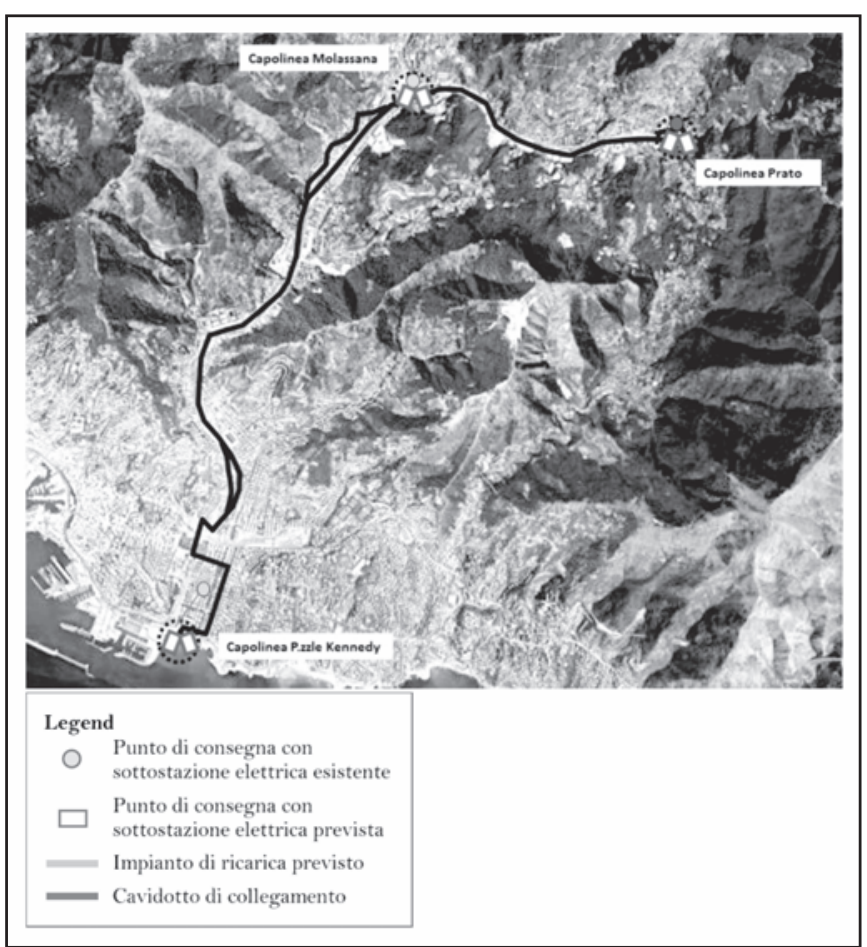

Figura 4 - Linea filoviaria con ricarica a capolinea.

per garantire la richiesta di trasporto si stima siano necessari 20 autobus circolanti contemporaneamente sulla linea con una frequenza di circa 4 minuti ${ }^{5}$.

La terza soluzione tecnologica consiste nella possibilità di utilizzare sulla linea dei bus totalmente elettrici: essi devono poter percorrere l'intero tracciato per poi ricaricarsi al momento della fermata al capolinea tramite un sistema di ricarica veloce, nell'ordine dei 5-7 minuti (Fig. 4). Diversamente dalla seconda soluzione, i mezzi necessitano di batterie di notevole dimensione disposte in serie in modo da garantire la marcia del veicolo lungo tutto il percorso. Anche in questo caso gli autobus hanno una lunghezza di 24 metri, ma con capienza leggermente inferiore, pari a circa 170 passeggeri; l'autonomia delle batterie (ciascuna del peso di 2,3 ton.) è pari a circa $230 \mathrm{Km}$. Per garantire la frequenza del servizio ogni 4 minuti, ai capolinea è necessario prevedere un punto di ricarica in più; in tal modo, mentre un autobus sta finendo la ricarica, una seconda vettura può iniziare ad utilizzare una seconda stazione di ricarica e, quindi, impiegare il tempo in più a disposizione per ricaricarsi. Per garantire la richiesta di trasporto si stima siano necessari 26 autobus circolanti simultaneamente sulla linea.

La seconda e la terza soluzione sono quindi molto simili dal punto di vista della modalità di alimentazione (con

\footnotetext{
${ }^{5}$ Per far fronte ad eventuali guasti o malfunzionamenti è previsto l'acquisto di 20 mezzi.
} 
batterie). Tuttavia, la differenza nell'inserimento di due soli punti di ricarica (per quella con ricarica a capolinea) o di circa 15 (per quella con ricarica a fermata) determina differenze, sia sul piano tecnico-economico sia su quello funzionale. Inoltre, le infrastrutture di supporto e le soluzioni impiantistiche necessitano di accorgimenti e strutture civili diverse.

\section{LA VALUTAZIONE DELLE TRE SOLUZIONI DI MOBILITÀ ATTRAVERSO L'ANALISI COSTI- BENEFICI}

Le tre soluzioni tecniche di mobilità urbana così definite sono state quindi valutate prendendo a riferimento le indicazioni del MIT per la selezione delle proposte di mobilità urbana che possono accedere alle risorse economiche destinate al potenziamento e alla realizzazione di sistemi di trasporto rapido di massa previste dalla Legge n. 232/2016 e confermate dalla Legge di Bilancio 2018

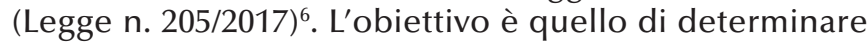
quale tra le tre soluzioni presenta il miglior rapporto tra costi e benefici e, quindi, potrebbe essere presentata dal Comune di Genova al MIT per il finanziamento dell'intervento ${ }^{7}$.

Nello specifico la Legge n. 232/2016 stabilisce che i progetti finanziabili possono riguardare:

- il rinnovo e miglioramento del parco veicolare;

- il potenziamento e la valorizzazione delle linee metropolitane, tranviarie e filoviarie esistenti;

- la realizzazione di linee metropolitane, tranviarie e filoviarie ed estensione/ implementazione della rete di trasporto rapido di massa, anche con sistemi ad impianti fissi di tipo innovativo.

Nell'avviso emesso dal MIT per la presentazione delle proposte da parte delle amministrazioni locali viene indicato che per i nuovi interventi si debba fare riferimento

\footnotetext{
6. Il relativo avviso emesso dal MIT I'1/03/2018 prevedeva che le amministrazioni pubbliche potevano presentare istanza per l'accesso alle risorse per il trasporto pubblico presentando le proposte entro il 31/12/2018; la successiva scadenza per la presentazione delle proposte era fissata al 30/09/2019 a seguito di nuovo avviso. In sede di presentazione della proposta di finanziamento, il Comune di Genova ha presentato il progetto delle 4 filoviarie con alimentazione aerea e il MIT ha approvato, nel 2020, un finanziamento complessivo pari a circa 470 milioni di euro per tutti e quattro gli 4 assi del trasporto pubblico della città. II Comune di Genova ha quindi richiesto al MIT di poter utilizzare parte del finanziamento anche per l'acquisto di autobus elettrici.

${ }^{7}$ Le tre proposte di mobilità sono state definite all'interno della Tesi di Laurea "Le trasformazioni della mobilità urbana" (candidati: Andrea Marcenaro e Giulio Minuto) discussa nel marzo 2019 presso I'Università di Genova - Scuola Politecnica; esse, quindi, non sono da considerarsi come specifiche proposte avanzate dal Comune di Genova.
}

alle disposizioni legislative del DM n. 300/2017 ${ }^{8}$ che prevedono che l'allocazione dei finanziamenti statali è subordinata alla presentazione dei progetti di fattibilità (o di progetti definitivi) delle singole infrastrutture e di un'Analisi Costi-Benefici (ACB) ${ }^{9}$. Secondo le indicazioni del MIT per le opere infrastrutturali che prevedono rientri tariffari le proposte devono prevedere (Ministero Infrastrutture e Trasporti, 2017a):

- un'analisi della domanda;

- un'analisi finanziaria con la quale si valuta l'equilibrio economico-finanziario dell'investimento sotteso alla realizzazione dell'opera;

- un'Analisi Costi-Benefici;

- un'Analisi di rischio e sensitività.

Relativamente all'analisi della domanda, questa deve interessare: la domanda "tendenziale" (ovvero il numero di spostamenti che si manifesterebbe in uno scenario senza la realizzazione della nuova infrastruttura); la domanda in "diversione modale" (ossia il numero di utenti che prima utilizzavano un'altra infrastruttura o sistema di trasporto); la domanda "indotta" (ossia gli utenti che si spostano per effetto della nuova infrastruttura e che prima non effettuavano lo spostamento).

L'analisi finanziaria deve consentire di valutare se l'opera è finanziariamente sostenibile - data la quota di cofinanziamento pubblico e il ricorso all'indebitamento - e se il progetto risulta bancabile alla luce delle condizioni attuali; essa deve essere condotta in relazione a possibili alternative (o scenari) progettuali identificate tra quelle che configurano modalità efficienti e/o efficaci per rispondere alla specifica esigenza.

Tra queste deve sempre essere presa in considerazione l'alternativa "senza intervento" ("do nothing" o "do minimum"); essa rappresenta lo scenario che prevede quegli investimenti e quella manutenzione necessari per mantenere in funzione l'infrastruttura esistente senza un deterioramento eccessivo. Tale scenario può anche prevedere costi aggiuntivi (contenuti) o investimenti già previsti e programmati dal gestore (scenario "Business as Usual").

Le diverse alternative selezionate da sottoporre a valutazione devono evidenziare differenze in ordine al tracciato, alle opzioni di potenziamento del servizio previ-

\footnotetext{
${ }^{8}$ Linee Guida per la Valutazione degli Investimenti in Opere Pubbliche nei settori di competenza del MIT; I'ultima versione è stata pubblicata I'1/06/2017 (MIT, 2017b).

${ }^{9}$ I progetti devono essere anche coerenti con i PUMS. Inoltre, per problemi di sostenibilità economica legata alla gestione del servizio, deve altresì risultare che i costi di gestione del servizio e dell'infrastruttura siano coperti per almeno il 35\% dai proventi derivanti dai rientri tariffari e che la residua quota sia coperta dalla Regione e/o dall'Ente beneficiario del contributo prioritariamente mediante il riordino dei servizi conseguente all'attivazione della nuova infrastruttura.
} 
ste, alle soluzioni tecnologiche e di processo costruttivo adottate o alle soluzioni gestionali (politiche di tariffazione, etc.) (Ministero Infrastrutture e Trasporti, 2017b). La metodologia da adottare per l'analisi finanziaria prevede che le entrate e i costi siano determinati applicando il metodo incrementale, ossia confrontando le entrate e i costi nello scenario comprendente il nuovo investimento ("scenario con intervento") con le entrate e i costi nello scenario senza il nuovo investimento (ovvero lo "Scenario di riferimento" $)^{10}$. I flussi di cassa devono essere considerati nell'anno durante il quale si manifestano e all'interno di un periodo di riferimento che, per le opere infrastrutturali (stradali e ferroviarie), può essere assunto pari a 25 anni (Ministero Infrastrutture e Trasporti, 2017b) $)^{11}$.

Sulla base della stima delle entrate e dei costi del progetto all'interno della vita utile sono quindi calcolati due indicatori di redditività:

- il Valore Attuale Netto Finanziario (VANF), ossia la somma dei flussi di cassa attualizzati al momento della valutazione (tempo "zero");

- il Tasso Interno di Rendimento Finanziario (TIRF), ossia il rendimento medio annuo dell'investimento.

Per il calcolo dei due indicatori il tasso di attualizzazione (o tasso di sconto) assume il significato di costo-opportunità del capitale impiegato nel progetto, inteso come il rendimento finanziario conseguibile dal suo migliore uso alternativo, a parità di rischio atteso ${ }^{12}$. A partire dalI'analisi finanziaria, le Linee Guida del MIT prevedono lo sviluppo dell'analisi economica; i valori finanziari sono trasformati in economici mediante l'applicazione di fattori di conversione ${ }^{13}$ e ai costi e benefici ascrivibili al soggetto investitore si aggiungono i benefici e i costi degli

\footnotetext{
${ }^{10}$ Sia le entrate che i costi dovranno poi essere calcolati a prezzi costanti e al netto dell'IVA, salvo nel caso in cui tale imposta non sia recuperabile dal gestore dell'opera.

${ }^{11}$ Se la vita economica effettiva del progetto supera il periodo di riferimento per la gestione dell'opera sarà necessario inserire tra i flussi di cassa - rilevanti per la compilazione del piano economico-finanziario - anche un valore residuo. Secondo le indicazioni delle Linee Guida del MIT (Ministero Infrastrutture e Trasporti, 2017b) tale valore può essere calcolato come differenza fra il costo iniziale dell'investimento e la cumulata delle rate di ammortamento (talvolta definito come "Fondo Ammortamento").

${ }^{12} \mathrm{Ai}$ sensi dell'art. 19 (Attualizzazione dei flussi di cassa) del Regolamento Delegato (UE) n. 480/2014 della Commissione, per il periodo di programmazione 2014-2020 la Commissione Europea consiglia di considerare un tasso di sconto finanziario pari al $4 \%$ in termini reali come parametro di riferimento per il costo opportunità reale del capitale nel lungo termine (European Commission, 2014).

${ }^{13}$ L'applicazione dei fattori di conversione consente di "correggere" $^{\prime \prime}$ i costi utilizzati nell'analisi finanziaria e ottenere importi al netto della tassazione e delle distorsioni dovute al cattivo funzionamento del mercato (per l'esistenza di posizioni monopolistiche, di prezzi amministrati, di dazi o di sovvenzioni).
}

utenti e della collettività attualizzati attraverso non più da un tasso di sconto finanziario ma da un tasso di sconto "sociale"14.

Al termine dell'attualizzazione dei benefici e dei costi del progetto, dovranno essere calcolati i seguenti indicatori di redditività economico e sociale:

- il Valore Attuale Netto Economico (VANE);

- il Tasso Interno di Rendimento Economico (TIRE);

- il rapporto Benefici/Costi (B/C).

Relativamente alle analisi economiche - e ai fini di agevolare il lavoro da parte delle Amministrazioni locali - la Direzione Generale per i Sistemi di Trasporto ad Impianti Fissi e il Trasporto Pubblico Locale ha siglato un protocollo d'intesa con la BEI e, in particolare, con l'European Investment Advisory Hub (EIAH) per lo sviluppo di procedure metodologiche relative all'applicazione delle disposizioni delle Linee Guida del $2017^{15}$.

\section{LA VALUTAZIONE FINANZIARIA ED ECONOMICA DELLE TRE SOLUZIONI PROGETTUALI}

Le tre soluzioni tecniche individuate sono state quindi valutate applicando le indicazioni delle Linee Guida del MIT che prevedono lo sviluppo di un'Analisi Costi Benefici (ACB) finanziaria ed economica. La tecnica è utilizzata per la valutazione della sostenibilità economica e finanziaria dei progetti pubblici (Nuti, 1987). In ambito trasportistico è stata utilizzata in diversi casi studio sia relativi a progetti di mobilità a livello urbano che extraurbano (Shefer e Haviram, 2005; Harford, 2006; Godinho e Dias, 2012; Hyard 2012; Gonzalez-Feliu, 2014; Margorínová e Trojanová, 2017). Alcuni autori hanno sperimentato l'applicazione dell'ACB in combinazione con altre tecniche, quali I'Analisi Multicriterio, per la selezione delle soluzioni trasportistiche (Tudela, Akiki e Cisternas, 2006; Guhnemann, Laird e Pearman, 2012).

Nel caso studio in oggetto, lo scopo dell'ACB è quello di verificare quale - delle tre alternative individuate - presenti le migliori performance in ordine agli indicatori riportati nelle Linee Guida del MIT.

La valutazione finanziaria ed economica si articola nelle seguenti fasi:

1) individuazione degli scenari progettuali da sottoporre a valutazione;

\footnotetext{
${ }^{14}$ La Commissione Europea, per il periodo di programmazione 2014-2020, consiglia di utilizzare un tasso di sconto sociale pari al 3\% (European Commission, 2014).

15 I protocollo d'intesa ha trovato quindi applicazione nell'Appendice all'Addendum dell'avviso del MIT nella quale sono riportate le "Tabelle di sintesi dell'analisi della mobilità urbana ACE/ACB - Istruzioni per la compilazione". Esse consentono di acquisire un quadro d'insieme delle informazioni richieste per l'esame e la valutazione delle istanze.
} 
2) individuazione dello scenario trasportistico di riferimento;

3) individuazione dei costi e dei benefici generati dalle tre alternative;

4) calcolo degli indicatori: Valore Attuale Netto Finanziario (VANF) ed economico (VANE), Tasso Interno di Redditività finanziario (TIRF) ed economico (TIRE), Periodo di Ritorno economico (PRE) e finanziario (PRF), rapporto Benefici e Costi (B/C) finanziario ed economico ${ }^{16}$.

Le soluzioni progettuali valutate attraverso I'ACB sono in tutto 4 (Tab. 1).

\section{Tabella 1 - Scenari e relative soluzioni considerate}

\begin{tabular}{c|l|l}
\hline Soluzione & Denominazione & $\begin{array}{l}\text { Caratteristiche } \\
\text { Mantenimento dei } \\
\text { mezzi oggi utilizzati } \\
\text { per il collegamento }\end{array}$ \\
\hline 1 & $\begin{array}{l}\text { Lusiness as Usual } \\
\text { mentazione da linea } \\
\text { aerea }\end{array}$ & $\begin{array}{l}\text { Nuova linea filobus } \\
\text { con mezzi alimentati } \\
\text { a contatto (cavi } \\
\text { aerei) }\end{array}$ \\
\hline 2 & $\begin{array}{l}\text { Linea filoviaria con rica- } \\
\text { rica a fermata }\end{array}$ & $\begin{array}{l}\text { Nuova linea filobus } \\
\text { con mezzi ricaricati } \\
\text { alle fermate }\end{array}$ \\
\hline 3 & $\begin{array}{l}\text { Linea filoviaria con rica- } \\
\text { rica a capolinea }\end{array}$ & $\begin{array}{l}\text { Nuova linea filobus } \\
\text { con mezzi ricaricati } \\
\text { ai capolinea }\end{array}$ \\
\hline
\end{tabular}

La soluzione 0 ("Business as Usual") è stata introdotta per poter sviluppare un'analisi di tipo "incrementale", in conformità alle indicazioni delle Linee Guida del MIT (Ministero delle Infrastrutture e dei Trasporti, 2017b); essa è configurata in modo tale che sia garantita la funzionalità base delle attività di trasporto esistenti, ossia la fornitura dei servizi trasportistici con livelli qualitativi simili a quelli rilevabili al momento della progettazione ed una limitata sostituzione di mezzi ed impianti.

Dal punto di vista gestionale essa presuppone che il livello degli interventi rimanga immutato, mantenendo il livello di spesa necessaria a garantire la funzionalità di base del sistema di trasporto pubblico. Gli scenari trasportistici presi a riferimento per le analisi sono determinati sulla base delle previsioni contenute nel Piano Urbano della Mobilità (PUM) del 2010 (ovvero il piano precedente al PUMS redatto nel 2018 ed approvato nel 2019, che rappresenta quindi lo stato di fatto pre-progettuale della proposta filoviaria) le quali definiscono un assetto trasportistico con e senza progetto; gli effetti sulla viabilità sono consi- derati analoghi per le diverse soluzioni tecnologiche oggetto della valutazione.

Tale assunzione è motivata dal fatto che le caratteristiche del servizio offerto sono da considerarsi uguali nelle tre soluzioni, per cui gli effetti sul sistema trasportistico urbano nel quale si inseriranno sono equivalenti ${ }^{17}$.

Tra gli scenari trasportistici riportati nel PUM del 2010 sono quindi stati selezionati quelli che risultano più adeguati a rappresentare il caso studio in oggetto.

In particolare:

- scenario di riferimento: considera solo i progetti per cui, al momento della stesura del PUM, esistevano atti istituzionali sottoscritti dal Comune di Genova nonché interventi atti a garantire il mantenimento di sufficienti standard di accessibilità. Tale scenario non comprende la realizzazione di nessuno degli assi di forza per il trasporto pubblico locale (TPL) e viene quindi adottato per la soluzione progettuale 0 ;

- scenario di prima fase realizzativa: consiste nell'insieme degli interventi che, secondo il cronoprogramma del PUM, sono da realizzarsi nel primo quinquennio. Tale scenario è quello che meglio approssima le soluzioni progettuali selezionate in quanto comprende solamente gli interventi sull'asse di forza, la realizzazione dei parcheggi di interscambio e la realizzazione delle Zone a Traffico Limitato (ZTL), limitatamente alla Val Bisagno. È quindi assunto come scenario di riferimento per le soluzioni progettuali 1, 2 e 3.

I principali indicatori trasportistici associati ai due diversi scenari sono riportati nella Tabella 2.

Tabella 2 - Principali indicatori trasportistici considerati

\begin{tabular}{c|c|c|c|c}
\hline \multirow{2}{*}{$\begin{array}{c}\text { Indicatore } \\
\text { Ripartizione } \\
\text { modale }\end{array}$} & $\begin{array}{c}\text { Privato } \\
\text { di riferimento } \\
64,5 \%\end{array}$ & $\begin{array}{c}\text { Pubblico } \\
35,5 \%\end{array}$ & $\begin{array}{c}\text { Privato } \\
62,3 \%\end{array}$ & $\begin{array}{c}\text { Pubblico } \\
37,7 \%\end{array}$ \\
\hline $\begin{array}{c}\text { Velocità } \\
\text { redia veicoli } \\
\text { privati }\end{array}$ & $\begin{array}{c}\text { Auto } \\
23,2 \mathrm{~km} / \mathrm{h}\end{array}$ & $\begin{array}{c}\text { Moto } \\
31,5 \mathrm{~km} / \mathrm{h}\end{array}$ & $\begin{array}{c}\text { Auto } \\
23,6 \mathrm{~km} / \mathrm{h}\end{array}$ & $\begin{array}{c}\text { Moto } \\
30,8 \mathrm{~km} / \mathrm{h}\end{array}$ \\
\hline $\begin{array}{c}\text { Velocità } \\
\text { media veicoli } \\
\text { pubblici }\end{array}$ & $\begin{array}{c}\text { Bus } \\
15,6 \mathrm{Km} / \mathrm{h}\end{array}$ & $\begin{array}{c}\text { Filobus } \\
-\end{array}$ & $\begin{array}{c}\text { Bus } \\
15,3 \mathrm{~km} / \mathrm{h}\end{array}$ & $\begin{array}{c}\text { Filobus } \\
22,7 \mathrm{~km} / \mathrm{h}\end{array}$ \\
\hline
\end{tabular}

I modelli trasportistici elaborati per il PUMS di Genova evidenziano, per le soluzioni progettuali considerate, un aumento dell'utenza per il TPL dovuto alla maggiore attrattività del nuovo sistema trasportistico della Val Bisagno. Esso cattura utenti non solo dal bus ma anche dalle

\footnotetext{
${ }^{16}$ Per una maggiore completezza delle analisi sulla sostenibilità finanziaria di ciascuna soluzione trasportistica, oltre agli indicatori riportati nelle Linee Guida del MIT è stato quindi calcolato anche il Periodo di Ritorno (sia finanziario che economico) e il rapporto Benefici/ Costi finanziario.
}

${ }^{17}$ Tali effetti sono stati determinati sulla base di un modello trasportistico sviluppato dalla Società d'Apollonia S.p.A. di Genova per l'intero ambito urbano genovese, secondo diversi livelli di intervento previsti dal Piano Urbano della Mobilità del Comune di Genova (Comune di Genova, 2010). 
moto e dall'auto; come conseguenza si osserva un lieve miglioramento della velocità di trasporto con l'auto ed una riduzione della velocità dei mezzi a due ruote (moto) per l'introduzione delle corsie protette dai cordoli che le rendono inutilizzabili da questi mezzi.

\subsection{L'analisi dei costi delle tre soluzioni progettuali}

I costi connessi alle tre soluzioni progettuali analizzate sono stati stimati distinguendoli secondo tre tipologie:

1) Costi diretti di investimento;

2) Costi di esercizio e manutenzione;

3) Costi esterni (indiretti).

Relativamente a costi diretti di investimento questi sono pertinenti ai costi di investimento iniziali e agli ulteriori costi in corso di attività dell'impresa, i cosiddetti "Capex"18.

In particolare sono stati quantificati i costi iniziali per la realizzazione delle opere civili e dell'impiantistica a supporto delle linee (interventi sulla sede stradale, adeguamento delle fermate e abbattimento delle barriere architettoniche, segnaletica, impiantistica, etc.) e per l'acquisto dei mezzi (comprese le eventuali opere di adeguamento alla soluzione tecnica adottata) (Tab. 3$)^{19}$.

\section{Tabella 3 - Costi di investimento delle soluzioni} analizzate

\begin{tabular}{|c|c|c|c|}
\hline Soluzione filoviaria & $\begin{array}{c}\text { Costo } \\
\text { unitario } \\
\text { filobus } \\
(€ / \text { cad.) }\end{array}$ & $\begin{array}{c}\text { Numero } \\
\text { mezzi } \\
(\mathbf{n} .)\end{array}$ & $\begin{array}{c}\text { Costo totale } \\
\text { ammissibile } \\
(€)\end{array}$ \\
\hline $\begin{array}{c}1 \text { - Con } \\
\text { alimentazione da } \\
\text { linea aerea }\end{array}$ & 1.000 .000 & 20 & 20.000 .000 \\
\hline $\begin{array}{c}\text { 2- Con ricarica a } \\
\text { fermata }\end{array}$ & 1.200 .000 & 23 & 27.600 .000 \\
\hline $\begin{array}{c}3 \text { - Con ricarica a } \\
\text { capolinea }\end{array}$ & 1.200 .000 & 30 & 36.000 .000 \\
\hline
\end{tabular}

Per quanto riguarda i costi di esercizio e rimpiazzo ${ }^{20}$ questi sono stati stimati sia per i mezzi impiegati in ciascuna soluzione di progetto sia per quelli operanti sulle linee bus principali $(13,14)$ e secondarie (collinari) (Tabella 4$)^{21}$.

\footnotetext{
${ }^{18}$ Contrazione di "CAPital EXpenditure", cioè di spese in conto capitale.

${ }^{19}$ Non sono invece compresi nell'analisi tutti i costi relativi alla realizzazione e/o l'adeguamento delle strutture per il ricovero degli automezzi (rimesse) e dei relativi costi per la loro infrastrutturazione.

${ }^{20}$ I costi di rimpiazzo sono relativi ai costi necessari per la sostituzione dei mezzi (autobus, filobus) e delle componenti (batterie, etc.) al termine della loro vita utile.

${ }^{21}$ Tali linee collegano il centro della città con il quartiere di
}

Tabella 4 - Costi di investimento delle soluzioni analizzate

\begin{tabular}{|c|c|c|c|}
\hline $\begin{array}{l}\text { Soluzione } \\
\text { filoviaria }\end{array}$ & $\begin{array}{l}\text { Costo unitario } \\
\text { annuale }\end{array}$ & Quantità & $\begin{array}{l}\text { Costo totale } \\
\text { (al netto } \\
\text { dell'IVA) }\end{array}$ \\
\hline \multicolumn{4}{|c|}{0 - Business as Usual (linee esistenti) } \\
\hline $\begin{array}{l}\text { Esercizio (ali- } \\
\text { mentazione) }\end{array}$ & $\begin{array}{c}1,4 \\
€ / \mathrm{Km}\end{array}$ & $\begin{array}{l}4.010 .000 \\
\text { Km/anno }\end{array}$ & $\begin{array}{c}5.614 .000 \\
\text { €lanno }\end{array}$ \\
\hline $\begin{array}{l}\text { Manuten- } \\
\text { zione mezzi }\end{array}$ & $\begin{array}{c}0,45-0,65 \\
€ / \mathrm{Km}\end{array}$ & 4.010 .000 & $\begin{array}{c}2.274 .500 \\
€ / \text { anno }\end{array}$ \\
\hline $\begin{array}{l}\text { Rimpiazzo } \\
\text { mezzi }\end{array}$ & $\begin{array}{c}185.000- \\
340.000 € / \text { cad. }\end{array}$ & 72 & $\begin{array}{c}17.809 .200 \\
€\end{array}$ \\
\hline \multicolumn{4}{|c|}{1 - Con alimentazione da linea aerea } \\
\hline $\begin{array}{l}\text { Esercizio (ali- } \\
\text { mentazione) }\end{array}$ & $\begin{array}{c}0,7 \\
€ / \mathrm{Km}\end{array}$ & $\begin{array}{l}1.854 .200 \\
\text { Km/anno }\end{array}$ & $\begin{array}{c}1.297 .940 \\
\text { €lanno }\end{array}$ \\
\hline $\begin{array}{l}\text { Manuten- } \\
\text { zione mezzi }\end{array}$ & $\begin{array}{c}26.500 \\
€ / \text { cad. anno }\end{array}$ & 20 & $\begin{array}{l}530.000 \\
€ / \text { anno }\end{array}$ \\
\hline $\begin{array}{l}\text { Rimpiazzo } \\
\text { mezzi }\end{array}$ & $\begin{array}{c}1.000 .000 \\
€ / \text { cad. }\end{array}$ & 20 & $\begin{array}{c}20.000 .000 \\
€\end{array}$ \\
\hline $\begin{array}{l}\text { Rimpiazzo } \\
\text { batterie }\end{array}$ & $\begin{array}{l}55.000 \\
€ / \text { cad. }\end{array}$ & 22 & $\begin{array}{c}1.100 .000 \\
€\end{array}$ \\
\hline $\begin{array}{l}\text { Rimpiazzi } \\
\text { linea aerea }\end{array}$ & $\begin{array}{c}500.000 \\
€ / \mathrm{Km}\end{array}$ & $23 \mathrm{Km}$ & $\begin{array}{c}11.500 .000 \\
€\end{array}$ \\
\hline \multicolumn{4}{|c|}{2 - Con ricarica a fermata } \\
\hline $\begin{array}{l}\text { Esercizio (ali- } \\
\text { mentazione) }\end{array}$ & $\begin{array}{c}0,85 \\
€ / \mathrm{Km}\end{array}$ & $\begin{array}{l}1.854 .200 \\
\text { Km/anno }\end{array}$ & $\begin{array}{c}1.576 .070 \\
\text { €lanno }\end{array}$ \\
\hline $\begin{array}{l}\text { Manuten- } \\
\text { zione mezzi }\end{array}$ & $\begin{array}{c}35.000 \\
€ / \text { cad. anno }\end{array}$ & 23 & $\begin{array}{l}805.000 \\
€ / \text { anno }\end{array}$ \\
\hline $\begin{array}{l}\text { Rimpiazzo } \\
\text { mezzi }\end{array}$ & $\begin{array}{l}1.100 .000 \\
\text { €/cad. }\end{array}$ & 23 & $\begin{array}{c}25.300 .000 \\
€\end{array}$ \\
\hline $\begin{array}{l}\text { Rimpiazzo } \\
\text { batterie }\end{array}$ & $\begin{array}{l}110.000 \\
€ / \text { cad. }\end{array}$ & 25 & $\begin{array}{c}2.750 .000 \\
€\end{array}$ \\
\hline $\begin{array}{l}\text { Rimpiazzo } \\
\text { stazioni rica- } \\
\text { rica }\end{array}$ & $\begin{array}{l}170.000 \\
€ / \text { cad. }\end{array}$ & 23 & $\begin{array}{c}4.140 .000 \\
€\end{array}$ \\
\hline \multicolumn{4}{|c|}{3 - Con ricarica a capolinea } \\
\hline $\begin{array}{l}\text { Esercizio (ali- } \\
\text { mentazione) }\end{array}$ & $\begin{array}{l}0,85 \\
€ / \mathrm{Km}\end{array}$ & $\begin{array}{l}1.854 .200 \\
\text { Km/anno }\end{array}$ & $\begin{array}{l}1.576 .070 \\
€ / \text { anno }\end{array}$ \\
\hline $\begin{array}{l}\text { Manuten- } \\
\text { zione mezzi }\end{array}$ & $\begin{array}{c}35.000 \\
€ / \text { cad. anno }\end{array}$ & 30 & $\begin{array}{c}1.050 .000 \\
\text { €/anno }\end{array}$ \\
\hline $\begin{array}{l}\text { Rimpiazzo } \\
\text { mezzi }\end{array}$ & $\begin{array}{c}1.200 .000 \\
\text { €/cad. }\end{array}$ & 30 & $\begin{array}{c}36.000 .000 \\
€\end{array}$ \\
\hline $\begin{array}{l}\text { Rimpiazzo } \\
\text { batterie }\end{array}$ & $\begin{array}{l}110.000 \\
€ / \text { cad. }\end{array}$ & 32 & $\begin{array}{c}3.520 .000 \\
€\end{array}$ \\
\hline $\begin{array}{l}\text { Rimpiazzo } \\
\text { del capolinea } \\
\text { di ricarica }\end{array}$ & $\begin{array}{l}180.000 \\
€ / \text { cad. }\end{array}$ & 6 & $\begin{array}{c}1.080 .000 \\
€\end{array}$ \\
\hline
\end{tabular}

Struppa, al confine nord-est del Comune di Genova, passando lungo tutta la Val Bisagno lungo l'asse stradale sulla sponda destra del fiume Bisagno. 
In particolare, per le linee 13 e 14 i costi dei rimpiazzi sono considerati solamente per la soluzione "Business as Usual" mentre per quelle secondarie sono stati considerati in tutte le soluzioni analizzate.

A tal fine le linee di bus secondarie sono state analizzate sia nella situazione attuale (Figura 6 - a sinistra) che di progetto (Fig. 6 - a destra), ossia modificate tenendo conto dell'inserimento della nuova linea filoviaria. I nuovi tracciati delle linee secondarie sono stati studiati in modo da minimizzare i percorsi inefficienti, cercando altresì di collegare le linee collinari direttamente con l'asse di forza principale (nuova filoviaria); questo ha portato alla soppressione delle linee 482 (raddoppiando la frequenza della linea 480) e della 470 barrata.

È da evidenziare che secondo lo scenario configurato dal PUM del 2010 (Comune di Genova, 2010), molte delle linee collinari non opereranno più da sole ma saranno appoggiate dal sistema di trasporto su domanda (Demand Responsive Transport - DRT). In relazione all'ampio arco temporale di riferimento, si considerano anche i rimpiazzi delle dotazioni impiantistiche a corredo delle linee; tra questi i costi delle sostituzioni delle batterie, stimati sulla base di una analisi condotta presso i fornitori di questo tipo di componenti. Per i costi di esercizio sono state considerate le spese di conduzione e alimentazione dei mezzi; è stata quindi considerata la differenza di onerosità per alimentazione dei mezzi elettrici o a motore termico mentre i costi legati al conducente sono stati considerati uguali. All'interno di questo gruppo di costi sono inclusi altresì quelli relativi all'assicurazione dei mezzi e la tassa statale di proprietà.

Per i costi di manutenzione ordinaria sono stati considerati quelli relativi alla manutenzione dei mezzi ovvero sia gli interventi relativi alle azioni manutentive periodiche che gli interventi atti a riportare da uno stato di avaria ad uno stato di buon funzionamento le componenti dei mezzi; per quanto riguarda invece i costi di manutenzione straordinaria, questi sono stati considerati inclusi nelle

\begin{tabular}{|c|c|c|c|c|c|c|c|c|c|c|c|c|c|c|c|}
\hline costi & netto importe & Ferzo & Notat Torale & 1 & 2 & 3 & 4 & 5 & $\because$ & \multirow{2}{*}{1} & \multirow[t]{3}{*}{ 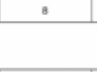 } & \multirow[t]{2}{*}{ - } & \multirow[t]{2}{*}{10} & \multirow[t]{2}{*}{11} & \multirow[t]{2}{*}{12} \\
\hline \multicolumn{4}{|c|}{ 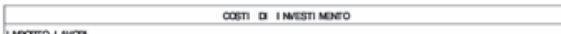 } & & & & & & & & & & \\
\hline 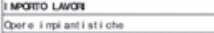 & 3.3202006 & $.061 .628 \mathrm{f}$ & & & & & . & & $\cdot$ & $\cdot$ & & & $\cdot$ & $\cdot$ & - \\
\hline 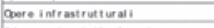 & 1.305 .4726 & $1.592 .675 \mathrm{E}$ & & 435.1576 & $255.167 \epsilon$ & 435.1576 & & . &. & $\because$ &. & - & 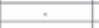 & . & - \\
\hline 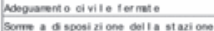 & $\begin{array}{l}1.034 .7206 \\
2010915\end{array}$ & $1.262 .358 \mathrm{E}$ & & $340907 \mathrm{E}$ & $344.907 \mathrm{E}$ & 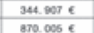 & . & . & $\dot{.}$ & $\therefore$ & $\therefore$ & $\cdot$ & $\therefore$ & $\therefore$ & $\therefore$ \\
\hline 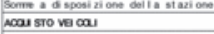 & 2610.0156 & $3184.218 \mathrm{e}$ & & $870.005 \mathrm{E}$ & $870.005 \epsilon$ & $870.006 \mathrm{e}^{-2}$ & & & & & & & & & \\
\hline 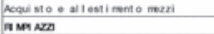 & $10.060 .000 \mathrm{e}$ & $12.529 .760 \mathrm{e}$ & & 5.3860006 & 5.306 .0006 & 5.3800006 & $\cdot$ & $\cdot$ & & & & & & & $\cdot$ \\
\hline 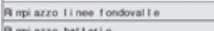 & 7.589 .484 e & $8.831 .000 \mathrm{C}$ & & . & . & & $\cdot$ & $\therefore$ & $\dot{-}$ & $-7.075 .5 \times 6$ & $\dot{-}$ & & & & \\
\hline Anpiszo bat terio & $3.100 .000 \mathrm{e}$ & $3.501 .000 \mathrm{C}$ & & & - & - & $\cdot$ & & & & & & 1.5050.000 C & & \\
\hline 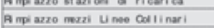 & $\begin{array}{l}2.200 .2068 \\
.1 .57 .6006\end{array}$ & -1.02060726 & & 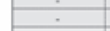 & $\because$ & $\div$ & $.107 .300 \mathrm{f}$ & . & . & $\therefore$ & . & $-1.50 .0006 \mathrm{G}$ & $\cdot$ & . & . \\
\hline Anp azzo lineses 470 & 222.2066 & 522026 & & & & & $214.6006 \mathrm{G}$ & & & & & & & & \\
\hline 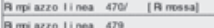 & .603 .8006 & $.785,4366$ & & $\cdot$ & C & $\cdot$ & .201 .9006 & & & & & & & & \\
\hline 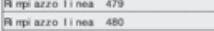 & $\frac{0 E}{2262006}$ & 06 & & & & & of & & & & & $.22 .000 \mathrm{E}$ & & & \\
\hline 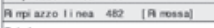 & $-1.000 .400 \mathrm{e}$ & $-1.300 .285 \mathrm{E}$ & & & & & & & & & & $-1.000 .400 \mathrm{e}$ & & & \\
\hline Treate & & $2338.908 \mathrm{E}$ & & $8005 \cos \epsilon$ & $20055.802 \epsilon$ & $8.0058002 \epsilon$ & .907 .9006 & & & 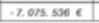 & & $1,380,000 \mathrm{e}$ & 1.5850000 $\mathrm{e}$ & & \\
\hline & $\cos \frac{\cos }{\cos }$ & & & & & & & & & & & & & & \\
\hline 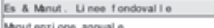 & -3700.6216 & -275062816 & & of & 06 & of & $.186 .574 \mathrm{f}$ & .164 .5746 & $-160.574 \mathrm{f}$ & .106 .5746 & .186 .5746 & .180 .5746 & $.186 .574 \mathrm{C}$ & .164 .5746 & .18055746 \\
\hline Es a mave. Unee collinari & $.27 .522 .508 \mathrm{f}$ & $.2 .586 .506 \mathrm{E}$ & & of & of & of & $-1.251 .209 \mathrm{E}$ & $-1.251 .209 \mathrm{E}$ & $-1.251 .200 \mathrm{e}$ & $-1.251 .20 \mathrm{E}$ & $-1.251 .209 \mathrm{\epsilon}$ & $-1.281 .20 \mathrm{E}$ & $-1.251 .290 \mathrm{E}$ & $-1.261 .200 \mathrm{E}$ & $-1.251 .209 \mathrm{f}$ \\
\hline 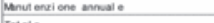 & -1.251 .2906 & $-1.281 .2096 \mathrm{E}$ & & & & & & & & & & & & & \\
\hline teateos & -31.231 .2076 & - $-31.231 .207 \mathrm{f}$ & & of & of & of & $1.42 .033 \mathrm{E}$ & -1.418 .836 & $-1.412 .036 \mathrm{G}$ & -1.418 .836 & 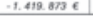 & - I. 428.836 & 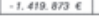 & -1.4828736 & $=.49 .836 \mathrm{E}$ \\
\hline TOKA OSE & 4.002 .2006 & 12.121.101 $\mathrm{E}$ & & $8.005 .002 \mathrm{C}$ & 2.005 .6026 & $2005.002 \mathrm{C}$ & $-1.527 .173 \mathrm{C}$ & \begin{tabular}{|c|}
$\mid-1.412 .878$ \\
\end{tabular} & $-1.412 .873 \mathrm{e}$ & -2.456 .4006 & $-1.412 .873 \mathrm{C}$ & -272.076 & $175.127 \mathrm{C}$ & $-1.412 .83 \mathrm{e}$ & $-1.412 .873 \mathrm{C}$ \\
\hline 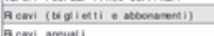 & $\begin{array}{l}3.004 .2046 \\
\end{array}$ & 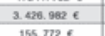 & & of & oe & of & $140.195 \mathrm{E}$ & $102.195 \mathrm{e}$ & $140.195 \mathrm{e}$ & $1202105 \mathrm{E}$ & $140.105 \mathrm{e}$ & 102056 & $140.05 \mathrm{E}$ & $106.295 \mathrm{e}$ & $180.105 \mathrm{E}$ \\
\hline 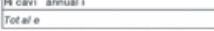 & $16.300 .154 \mathrm{E}$ & 20.026006 & & of & of & of & $100.106 \mathrm{E}$ & $740.195 \mathrm{E}$ & 100.1956 & $140.195 \epsilon$ & 18001956 & 100. $195 \mathrm{E}$ & $160,196 \mathrm{E}$ & 140. $195 \mathrm{E}$ & 100.1566 \\
\hline FOKK BRATIE & $10.500 .154 \mathrm{E}$ & $20.00 .700 \mathrm{C}$ & & of & of & of & $140.725 \mathrm{E}$ & I $120205 \mathrm{e}$ & $140.105 \mathrm{E}$ & $1020.96 \mathrm{e}$ & $140.105 \mathrm{E}$ & $100.105 \mathrm{e}$ & $190.056 \mathrm{e}$ & $100.105 \mathrm{e}$ & $190.105 \mathrm{E}$ \\
\hline$x^{2}$ & $\cos 150000000040$ & & & & & & & & & & & & & & \\
\hline 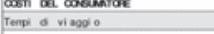 & $-108258 \mathrm{me}$ & & & $0 \in$ & $0 \varepsilon$ & 06 & -8.025 .4196 & $.8656 .419 \mathrm{C}$ & $-8.828 .4196<$ & .865 .4196 & $-8.685 .4196 \mathrm{C}$ & .2625 .4196 & -8.683 .4196 & $\therefore 8.05 .4196$ & $-8086.410 \in$ \\
\hline 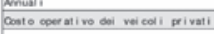 & 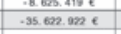 & 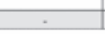 & & $0 €$ & $0 \in$ & of & $-1.612 \mathrm{mat}$ & $-1.610 .274 \mathrm{E}$ & -1.612 .246 & $-1.612 .2 \mathrm{AC}$ & $-1.612 .24 \mathrm{e}$ & $-1.619 .224 \mathrm{e}$ & -1.612 .246 & $.0 .612204 \mathrm{e}$ & $-1.619 .224 \mathrm{E}$ \\
\hline 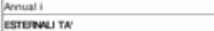 & $-1.612 .224 \mathrm{e}$ & & & & & & & & & & & & & & \\
\hline incionti & \begin{tabular}{|l|}
-13.705 .000 \\
\end{tabular} & $\dot{-}$ & & of & oe & of & .0057006 & .0257006 & .005 sose & $.605 .705 \mathrm{C}$ & $.05 \pi 006$ & $.605 .700 \mathrm{e}$ & $-\cos \pi 00$ & -62587006 & .025006 \\
\hline 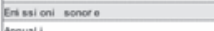 & $-2077.9006 \mathrm{C}$ & . & & of & of & of & .1300106 & .130 .8106 & .130 .106 & $-180.010 \mathrm{C}$ & $.1300186 \mathrm{C}$ & .100 .0106 & .130 .0106 & .130 .0106 & $.130 .010 \mathrm{f}$ \\
\hline 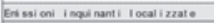 & \begin{tabular}{|l|l|}
.256507 .7006 \\
\end{tabular} & $\therefore$ & & 06 & 06 & of & $-1.165250 \mathrm{E}$ & $-1.105220 \mathrm{E}$ & $-1.1465 .809 \mathrm{E}$ & $-1.1652209 \mathrm{E}$ & $-1.465 .2806 \mathrm{G}$ & $-1.10552209 \mathrm{E}$ & $-1.465 .250 \mathrm{G}$ & $-1.1052209 \mathrm{E}$ & $-1.1452200 \mathrm{E}$ \\
\hline & & & & & & & & & & & & & & & \\
\hline Mnouli a ditatid & 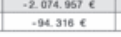 & & & $0 \varepsilon$ & of & 06 & . $4.316 \mathrm{e}$ & .94 .3186 & $-9.316 \mathrm{e}$ & .43166 & $.4 .318 \mathrm{e}$ & restoc & $.92 .316 \mathrm{e}$ & $.9316 \mathrm{C}$ & .94.318 $\mathrm{E}$ \\
\hline & \begin{tabular}{|l|}
$\mid-270.600 .8706 \mathrm{e}$ \\
\end{tabular} & & & of & of & of & . .12301 .4046 & |.12.301.056 6] & $\mid .12301 .404 \mathrm{G}$ & $\mid-12.201 .60 \mathrm{f}$, & $.12301 .404 \mathrm{E}$ & $.12 .301 .000 \mathrm{G}$ & . $12301.404 \mathrm{E}$ & $-12.301 .605 \mathrm{f}$ & $.12301 .404 \mathrm{f}$ \\
\hline Fusso Ecoson $\infty$ & & & & .8056 .8006 & -8.0058026 & $.0060 .002 \mathrm{f}$ & 13.20en $\mathrm{mI} \mathrm{G}$ & $12.851 .471 \mathrm{G}$ & 13.661.471 $\in$ & $20.007 .007 \in$ & 13.861.471 $\mathrm{G}$ & 15.22 .4716 & 12286.4716 & $|12.601 .47, \in|$ & $13.260 .471 \epsilon$ \\
\hline Stapositi inoes & & & & $-8.005 .8002 \mathrm{e}$ & -18.560.304 $\mathrm{E}$ & 1.25 & met & 3900 & $14.252 .160 \mathrm{e}$ & 35.190.001 f & $40.055 .592 \mathrm{E}$ & 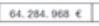 & $76.557 .606 \mathrm{f} \mid$ & $80.226 .056 \mathrm{f}$ & $104.27 .5005 \mathrm{e}$ \\
\hline 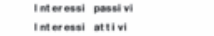 & & & $\begin{array}{l}0.01 x \\
0.01 x\end{array}$ & & $.400 .750 \mathrm{e}$ & -8020.600 e & & C41. 40 40 & 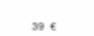 & $1.425 \mathrm{f}$ & $2.519 \mathrm{f}$ & $4000 \mathrm{f}$ & $0.428 \mathrm{f}$ & $7.056 \mathrm{f}$ & 9.035 e \\
\hline 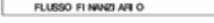 & & & -1 & -800560006 & $-8.6002 .926\}$ & $.825 .622 \mathrm{E}$ & 12.6287716 & $1820.000 \mathrm{E}]$ & $13.861 .510 \mathrm{G}$ & $200006.036 \mathrm{f}$ & $13.866 .900 \mathrm{E}$ & $18.28 .37 \mathrm{f}$ | & $1222.200 \mathrm{E}$ & $12.000 .127 \mathrm{\epsilon}$ | & $13870.54 \mathrm{E}$ \\
\hline Russo nimen in o scorraro & & & 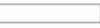 & $-7.800 .002 \mathrm{e}$ & $-8.012 .624 \mathrm{E}$ & $-8186.208 \mathrm{f}$ & $11.27 .273 \mathrm{E}$ & $11.400 .602 \mathrm{E}$ & $11.606 .797 \mathrm{E}$ & 17.020 .828 e & $10.925 .151 \mathrm{E}$ & $11.6720 .99 \mathrm{e}$ & $0.122 .190 \mathrm{e}$ & $10.010 .3 \mathrm{sg}$ e & $0.728 .490 \mathrm{E}$ \\
\hline 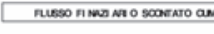 & & & & -7.000 .0006 & 15027.620 & .24 .040 .005 & $\begin{array}{ll}-12766.561 \mathrm{C} \\
\end{array}$ & $\mid-1,350.000$ & $10.24 .256 \mathrm{C}$ & 27.2ratese & 30.210.211. & 22.050 .0500 & 50.023 .180 & 62.025006 & $70.71,002 \mathrm{e}$ \\
\hline 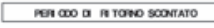 & & & $\bar{E}$ & cm & & & & & & & & & & & \\
\hline V.Ak $\cos 00$ & & & - & troos me & & & & & & & & & & & \\
\hline T.1.n в & & & D & 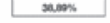 & & & & & & & & & & & \\
\hline
\end{tabular}

Figura 5a - Analisi Costi-Benefici economica per la soluzione con ricarica a fermata (soluzione 2). 
Mobilità sostenibile e sostenibilità economica: il caso della nuova linea filoviaria a Genova

\begin{tabular}{|c|c|c|c|c|c|c|c|c|c|c|c|c|c|c|c|c|}
\hline costi & mento inponte & Treno & Woet toas. & 13 & in & 15 & 16 & 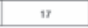 & 18 & 19 & 20 & 21 & $n$ & $n$ & 24 & \% \\
\hline \multicolumn{17}{|c|}{ con a inestiverio } \\
\hline 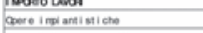 & 2.200 .2006 & 4.061 .2246 & & . & 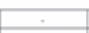 & 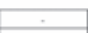 & $\therefore$ & & & 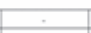 & $\therefore$ & 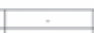 & 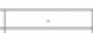 & 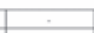 & & 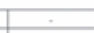 \\
\hline 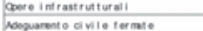 & 1.005 .426 & $\frac{1.502 .6756}{1.203856}$ & & & & & & & & & & & & & & \\
\hline \multicolumn{16}{|c|}{ 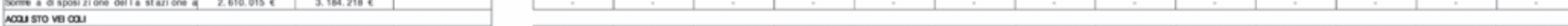 } & 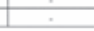 \\
\hline 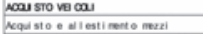 & 16.000 .0006 & & & $\square$ & . & & $\therefore$ & $\therefore$ & $\therefore$ & $\therefore$ & $\because$ & & & & & \\
\hline \multicolumn{16}{|l|}{ 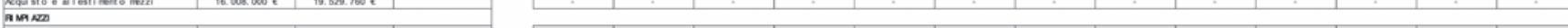 } & \\
\hline 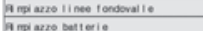 & 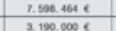 & 8.81 .0506 & & & $=$ & $\pi$ & & 4.0050000 & & 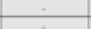 & 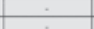 & - & & 14.67.0006 & & \\
\hline 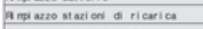 & 2.001 .2006 & $2.090 .04 \mathrm{C}$ & & & & & & 1.sonse & & & & & & $2.401 .200 \mathrm{C}$ & & \\
\hline 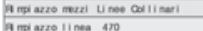 & $\frac{-1.57 .6006}{40.2006}$ & $\frac{-1.222628}{530284}$ & & & 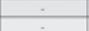 & $=$ & 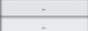 & & & & & & & & - $107.3006 \mathrm{c}$ & \\
\hline 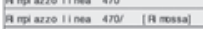 & -63.6006 & -7034066 & & & & & & & & & & & & & $\frac{212606}{22.2006}$ & \\
\hline 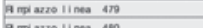 & of & of & & 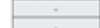 & & & $\therefore$ & & $=$ & & 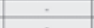 & 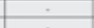 & $\therefore$ & & of & \\
\hline 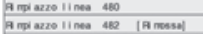 & $\frac{.222 .0006}{.1 .0000006}$ & $\begin{array}{l}.325256 \\
-1.30256 \\
6\end{array}$ & & & & & & & & & & & & & & \\
\hline \multirow{2}{*}{\multicolumn{17}{|c|}{ 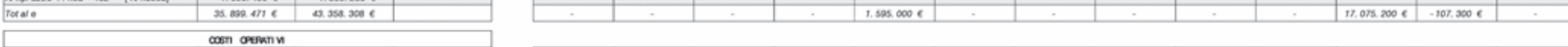 }} \\
\hline & & & & & & & & & & & & & & & & \\
\hline 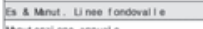 & .270062816 , & -3.386 .628 & & $.180859 \mathrm{e}$ & $.1885974 \mathrm{e}$ & .1805974 & 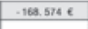 & seasuce & .1865946 & -1808574 & -186.5746 & .86 .5746 & $.86054 \mathrm{e}$ & $.188594 \mathrm{e}$ & $.18059 \mathrm{~s}$ e & $.162594 \mathrm{e}$ \\
\hline 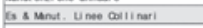 & -27.5250 .966 & -2.5285006 & & 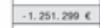 & $-1.251 .200 \mathrm{C}$ & $-1.251 .20 \mathrm{C}$ & $-1.281 .200 \mathrm{C}$ & $-1.251 .20 \mathrm{C}$ & $-1.251 .200 \mathrm{C}$ & $-1.251 .20 \mathrm{C}$ & $-1.251 .200 \mathrm{C}$ & $-1.201 .200 \mathrm{C}$ & $-1.251 .200 \mathrm{C}$ & $-1.251 .2200 \mathrm{C}$ & $-1.251 .200 \mathrm{C}$ & -1.281.200 $\mathrm{c}$ \\
\hline & & -1.21 .2018 & & & & & & & & & & & & & & \\
\hline Frodelo & -3.287 .2076 & $-31.237 .207 \mathrm{e}$ & & 1.4.12887e & -1.412 .8736 & 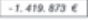 & $-1.418 .87\}$ & -1.412.873 & -1.412 .878 & -1.410 .8736 & -1.472 .8736 & $-1.412 .873 \mathrm{E}$ & $-1.412 .873 \mathrm{E}$ & C.412.878 & 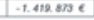 & -1.49 .878 \\
\hline \multirow[t]{2}{*}{ TOME COSI } & 4.6622646 & 12.127. $101 \mathrm{G}$ & & -1.412 .0736 & 1.498786 & -1.410 .8736 & -1.410 .026 & 178.1276 & -1.419 .8736 & -1.418 .836 & 1..412.836 & $\mid-1.428 \mathrm{erc}$ & \begin{tabular}{|l|l|}
-1.4128736 \\
\end{tabular} & 18.65 .3796 & $\mid-1.527 .136 \mathrm{E}$ & $1-1.4128 \mathrm{gnc}$ \\
\hline & extrate & & & & & & & & & & & & & & & \\
\hline 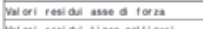 & 1396.3946 & 17.841 .4506 & & $\therefore$ & 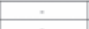 & $\therefore$ & ${ }^{\circ}$ & - & $x^{2}+2$ & -1 & & $x^{2}+2$ & $\therefore$ & $x_{1}$ & & 12989.3916 \\
\hline 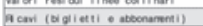 & 2.004 .2846 & 3.46 .0282 & & $100.195 \mathrm{E}$ & $140.195 \mathrm{e}$ & $140.105 \mathrm{E}$ & 100.1056 & $100.16 \mathrm{e}$ & $100.195 \mathrm{e}$ & $140.95 \mathrm{e}$ & $190.105 \mathrm{E}$ & $180.05 \mathrm{E}$ & $100.105 \mathrm{e}$ & $140.195 \mathrm{e}$ & $140.95 \mathrm{e}$ & $140.0506 \mathrm{E}$ \\
\hline Acari monati & 100.1956 & & & & & & & & & & & & & & & \\
\hline trate & 10.501 .1846 & $20000700 \mathrm{C}$ & & He. $128 \mathrm{C}$ & $1020205 \mathrm{E}$ & $100.1856 \mathrm{G}$ & $100.158 \mathrm{E}$ & 160. $138 \mathrm{C}$ & 100. $728 \mathrm{e}$ & 100. $198 \mathrm{c}$ & $108.98 \mathrm{C}$ & 100.056 & 150. $195 \mathrm{e}$ & 180. $128 \mathrm{C} \mathrm{C}$ & $1800.1856 \mathrm{E}$ & $12.356 .005 \mathrm{r}$ \\
\hline \multirow[t]{2}{*}{ Forme eanive } & $16.300 .154 \mathrm{E}$ & $20.028 .700 \mathrm{e}$ | & & $100.136 \mathrm{e}$ & $140.195 \mathrm{e}$ & $180.105 \mathrm{E}$ & 182.1056 & $100.186 \mathrm{e}$ & $180.195 \mathrm{e}$ & 190 1958 e & \begin{tabular}{ll|}
140.9056 \\
\end{tabular} & I 180.1056 & $100.186 \mathrm{C}$ & I $140.185 \mathrm{E}$ & $140.195 \mathrm{e}$ & $13.386 \cos \mathrm{E}$ \\
\hline & 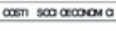 & & & & & & & & & & & & & & \\
\hline 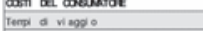 & the $350 \mathrm{~ms}$ & & & $-1085,1106$ & -1.050 .4106 & $-0.658 .419 \mathrm{C}$ & -0.65 .4196 & $-\cos 4.485$ & -2.65 .419 \& & .1054109 & -2.054196 & -2.05 .4196 & $-\operatorname{tac5} 419 \mathrm{G}$ & -260.4196 & -2.056406 & -0.050 .4196 \\
\hline & & & & & & & & & & & & & & & & - \\
\hline 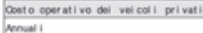 & 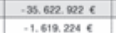 & & & -1.612 .284 & -1.6192846 & -1.612 .246 & 1.612284 & -1.612 .2246 & -1.692 .2846 & -1.619 .246 & -1.672 .246 & -1.678 .246 & -1.618 .2246 & -1.619 .284 & -1.612 .246 & -1.612 .246 \\
\hline \multicolumn{17}{|l|}{ 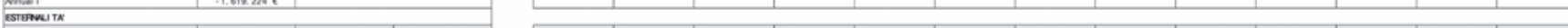 } \\
\hline mectoneti & 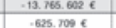 & $=$ & & sestose & sesone & 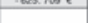 & sescose & . & sesone & 402000 & $\sin \theta$ & .08 .006 & .60 .000 & . os & .085006 & 625.7086 \\
\hline andion sonat & 287.006 & 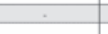 & & \begin{tabular}{|l|l|}
$.130 .618 \mathrm{e}$ \\
\end{tabular} & $.130 .618 \mathrm{C}$ & .190 .0186 & -180.8186 & $-130.818 \mathrm{e}$ & .130 .8186 & -130.8186 & -190.8186 & $-180.618 \mathrm{\epsilon}$ & $-130.818 \mathrm{C}$ & $.130 .818 \mathrm{C}$ & $-130.818 \mathrm{C}$ & -1930.8186 \\
\hline 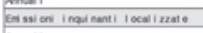 & 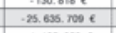 & & & \begin{tabular}{|l|l}
$.1655250 \mathrm{C}$ \\
\end{tabular} & $-1.165 .250 \mathrm{C}$ & -1.1855 .306 & $-1.1852259 \mathrm{C}$ & -1.18552596 & $-1.165 .259 \mathrm{e}$ & $-1.1655850 \mathrm{C}$ & -1.1855896 & $-1.165250 \mathrm{C}$ & $-1.1852259 \mathrm{C}$ & $.4 .165 .280 \mathrm{C}$ & $-4.16550 \mathrm{e}$ & -1.1855806 \\
\hline 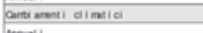 & -2004.0556 & & & $.2 .316 \mathrm{e}$ & -rasece & -2.164 & $-2.216 \mathrm{c}$ & $-9.310 \mathrm{e}$ & $.2 .316 \mathrm{c}$ & -rsiec & -2estec & -9.1166 & $-24.316 \mathrm{e}$ & 2.2.186 & $.2 .316 \mathrm{C}$ & -2e.16e \\
\hline \multirow{2}{*}{\multicolumn{4}{|c|}{ 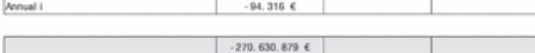 }} & & & & & & & & & & & & & \\
\hline & & & & -12.280 .0046 & .12 .801 .4046 & $.12301 .404 \mathrm{C}$ & $-12.301 .400 \mathrm{C}$ & -12301.6046 & -12301.046 & $\mid \cdot 12.201 .4046$ & $\mid-12301.4046$ & |. 12.301.456 6 & $\mid-12301.64$. & T-12.301.654 6 & $1-12.200 .4046$ & $1.12301 .404 \mathrm{E}$ \\
\hline \multicolumn{4}{|l|}{ russo ecosun 00} & 1286.476 & $13.061 .271 \mathrm{G}$ & 13.851.281 G & $13.851 .47 \mathrm{C}$ & 128664716 & 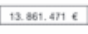 & $13.861 .67 \mathrm{G}$ & $13.851 .471 \mathrm{G}$ & 13.65.671 G & 13.667 .476 & 1.3213 .706 & 1 13.06. $\mathrm{m} / \mathrm{f}$ & 20.07 .326 \\
\hline \multicolumn{4}{|l|}{ Stopeations } & $116.160 .00 \mathrm{C}$ & $12.0202 \mathrm{cmc} C$ & 145.97 .3746 & 150.70 .4786 & 12.005 and $\mathrm{C}$ & 108.854 .6076 & 100.02604 & 2127140006 & 207.sen.2016 & 241.40 .1006 & 1200.200 .526 & 1252.256 .1006 & $1272 \operatorname{sen} 7506$ \\
\hline \multicolumn{3}{|l|}{ 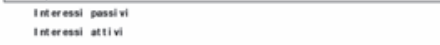 } & $\begin{array}{l}5 x \\
0,015 \\
0,015\end{array}$ & 10.406 & 11.817 $\mathrm{e}$ & $13.204 \mathrm{E}$ & 12.026 & 15.906 & $17.206 \mathrm{e}$ & $18.565 \mathrm{E}$ & 12.036 & 21.3n $\mathrm{E}$ & 2. now & 24.48: & 2.6296 & $25.28 \mathrm{e}$ \\
\hline \multicolumn{4}{|l|}{ 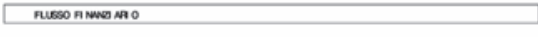 } & 1287.0016 & $12022306 \mathrm{f}$ & $13.87466 \mathrm{G}$ & 13.8760606 & 12202.4516 & $1287.679 \mathrm{C}$ & $12800.067 \mathrm{f}$ & $13.81 .255 \mathrm{C}$ & 13.0202006 & 12804.2316 & 1.2 .00 .5006 & 13.962 .6016 & $20.100580 \mathrm{C}$ \\
\hline \multicolumn{4}{|l|}{ 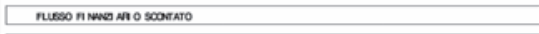 } & 2.24600006 & 2.176 .8786 & $2.065 .626 \mathrm{C}$ & a.647.104 C & r. 2a1. $\cos \mathrm{C}$ & $0.152 .261 \mathrm{C}$ & $7.915 .600 \mathrm{e}$ & $7.005 .625 \mathrm{C}$ & $7.421272 \mathrm{G}$ & 1.24ate one $\mathrm{e}$ & $\mid-1.618 .1396$ & 16802.426 & 12.04asecte \\
\hline \multicolumn{4}{|c|}{ 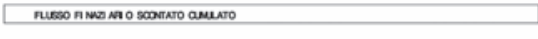 } & 0 & 97.36 .0 & 106804 & W & 122.32 .0 & 120.2580 & 159.40 .6 & $166126:$ & $1 \operatorname{sis} 2 \sin 2$ & 100008.8 & 159.218 .16 & 1466.120 .590 & 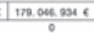 \\
\hline \multicolumn{4}{|l|}{ 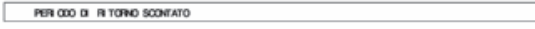 } & & & & & & & & & & & & & \\
\hline \multicolumn{4}{|l|}{ V.AN Ecoson $\infty$} & & & & & & & & & & & & & \\
\hline \multicolumn{4}{|l|}{ T.,R R 10000000} & & & & & & & & & & & & & \\
\hline
\end{tabular}

Figura 5b - Analisi Costi-Benefici economica per la soluzione con ricarica a fermata (soluzione 2).

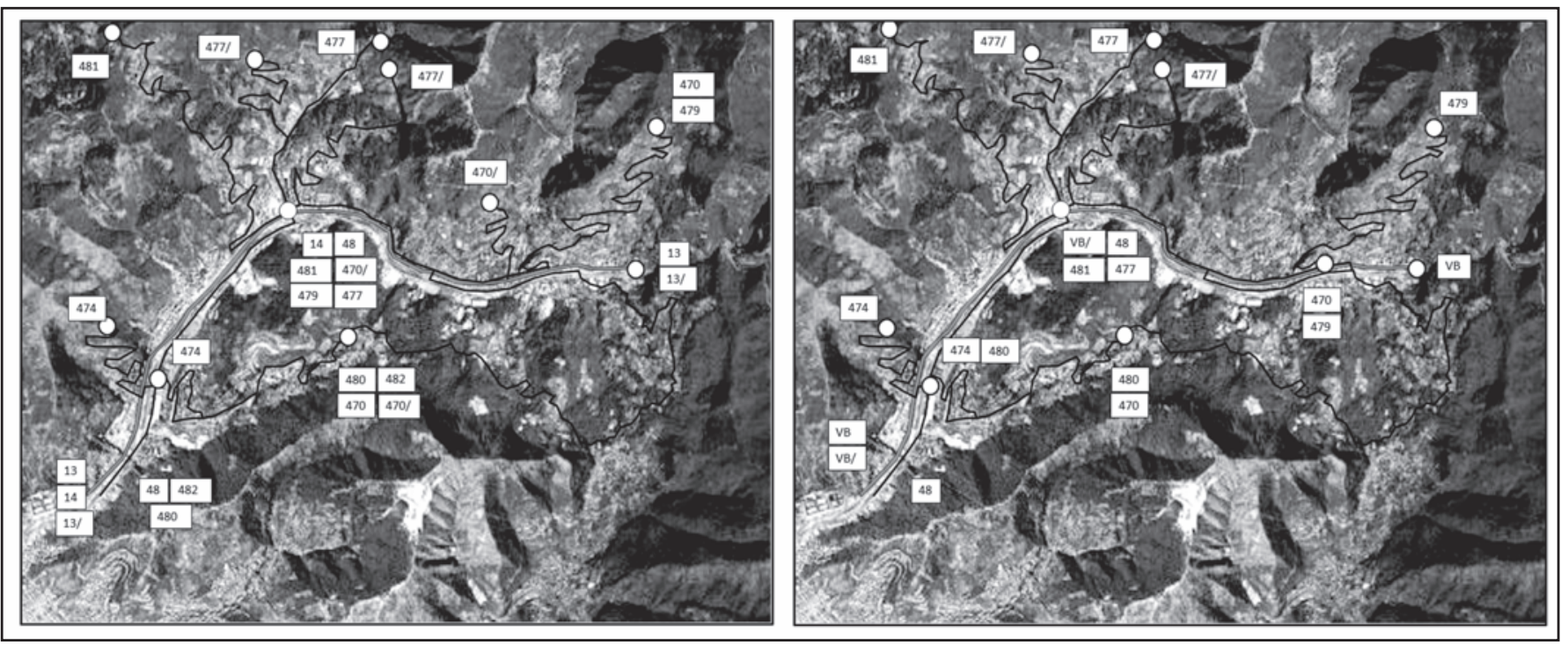

Figura 6 - Linee autobus (linee nere) esistenti (a sinistra) e di progetto (destra) al contorno della nuova linea filoviaria di fondovalle. 
polizze o nei contratti di leasing stipulati presso le aziende fornitrici dei mezzi22.

I costi considerati nell'ACB sono quelli "ammissibili" ossia al netto dell'imposizione fiscale (IVA).

Per i costi "esterni", invece, sono stati considerati tutti i costi sostenuti da quella parte di collettività interessata dalle soluzioni progettuali oggetto dell'analisi ${ }^{23}$. II primo gruppo di costi considerati è costituito dai cosiddetti "costi dei consumatori" tra i quali assumo particolare importanza i costi relativi ai tempi di viaggio e i costi operativi dei veicoli privati. Nel primo caso sono stati valutati mediante un prezzo orario determinato sulla base del procedimento adottato dal PUMS della Città Metropolitana di Genova del 2018: a partire dal PIL pro-capite annuo ligure (da fonte ISTAT) è stato calcolato l'ammontare del PIL per occupato e, sulla base delle ore annue di lavoro, è stato quindi desunto il valore medio orario, pari a circa 36,29 euro $^{24}$. Le percentuali degli spostamenti presi a riferimento per l'applicazione dei costi sostenuti dai cittadini sono le seguenti (Comune di Genova, 2010):

- spostamenti per "Lavoro": 14\%;

- spostamenti per "Affari": $22 \%$;

- spostamenti per "Altri motivi": $8 \%$.

Successivamente si sono quindi calcolati i tempi di percorrenza delle tratte con i differenti mezzi considerati nelI'analisi (automobile, scooter, autobus e filobus) desunti dalle velocità medie riportate nella simulazione trasportistica adottata, sia nello scenario progettuale che nel "Business as Usual".

Per valutare il numero di persone coinvolte, per le quali considerare il costo del tempo, si sono applicate - ai volumi di viaggiatori presi a riferimento per il calcolo delle entrate - le percentuali relative alla ripartizione modale ottenendo quindi i volumi di viaggiatori relativi alle diverse categorie di veicolo privato. Relazionando tali quantità alle motivazioni degli spostamenti, sono stati quindi stimati i costi complessivi sostenuti per i tempi di viaggio. Per il calcolo delle "esternalità" generate dalle soluzioni in termini di inquinamento acustico, atmosferico e le relative quantificazioni economiche si è fatto riferimento

\footnotetext{
${ }^{22}$ I costi di esercizio e manutenzione sono stati quantificati sulla base delle indicazioni e dei dati forniti da AMT che svolge il servizio di TPL. A seconda della natura del costo, questo è stato quantificato in un costo a mezzo (€/mezzo) o in un costo a km (€/km di linea).

${ }^{23}$ Nell'analisi economica, per la stima dei costi e dei benefici che interessano la collettività si è fatto riferimento alle indicazioni contenute nelle Linee Guida del MIT (MIT, 2017b), considerando gli utenti delle linee di trasporto per l'ambito territoriale analizzato (attuali e indotti), degli utenti della strada e la collettività (residenti) in termini di inquinamento acustico ed atmosferico.

${ }^{24}$ I costi per i tempi di viaggio calcolati sono: 5,1 /ora per gli spostamenti per lavoro; 8,0 /ora per gli spostamenti per affari; 2,9 $€ /$ ora per gli spostamenti per altri motivi.
}

allo studio sviluppato da INFRAS (INFRAS, 2004) che fornisce i coefficienti da applicare ai km percorsi dalle diverse tipologie di mezzi di trasporto al fine di stimare gli "external cost" generati.

\subsection{L'analisi dei benefici delle tre soluzioni progettuali}

Le entrate sono rappresentate da tutte le voci positive a bilancio che derivano essenzialmente da due fattori: la bigliettazione e i valori residui dei mezzi al termine dell'intervallo temporale considerato nell'analisi finanziaria ed economica (25 anni).

Per quanto riguarda la bigliettazione, gli utenti del mezzo pubblico sono stati distinti in funzione del titolo di viaggio: possessori di biglietto a scadenza oraria ${ }^{25}$; possessori di abbonamento mensile; possessori di abbonamento annuale. L'importo complessivo è quindi calcolato considerando sia il numero di utenti che già utilizzano i mezzi delle linee interessate sia i nuovi utenti generati dalle soluzioni di progetto, assumendo analoghe percentuali di distribuzioni delle tre tipologie di titolo di viaggio. In particolare si sono utilizzati i dati relativi alla distribuzione media dei flussi di persone lungo la tratta misurata con il metodo delle sezioni di carico, quantificando in tal modo la quantità giornaliera dei viaggi da moltiplicare quindi per le differenti aliquote di titoli di viaggio.

Per lo scenario 0 ("Business as Usual") si è assunto che gli utenti delle linee rimanessero invariati, assumendo quindi i dati registrati periodicamente da AMT in merito al numero di utenti sulle linee; per le ipotesi di progetto, invece, si sono stimati degli incrementi nel numero di utenti basandosi sulle percentuali di ripartizione modale definiti per gli scenari trasportistici analizzati. Per i nuovi utenti si sono applicate le stesse ripartizioni dei titoli di viaggio e gli stessi prezzi dei titoli rilevati all'anno 2019.

La tabella 5 riporta i ricavi della linea filoviaria con ricarica a fermata (soluzione 2).

Per quanto riguarda invece i valori residui dei mezzi, si è assunta l'ipotesi che il deprezzamento sia lineare e che il valore alla fine della vita utile sia uguale a zero. Ai fini dello sviluppo del modello di ACB e del calcolo degli indicatori di sostenibilità, per i mezzi acquistati si è considerata una vita utile di 20 anni, con una sostituzione degli stessi programmata quindi alla fine del $23^{\circ}$ anno. La tabella 6 riporta i valori residui della linea filoviaria con ricarica a fermata (soluzione 2).

\footnotetext{
${ }^{25}$ Il contributo è stato determinato considerando che all'interno del periodo temporale di validità del biglietto (100 minuti) sia possibile compiere un viaggio sull'intera tratta in oggetto. Le differenti aliquote dei titoli di viaggio sono state fornite da AMT.
} 
Tabella 5 - Entrate previste per la filoviaria con ricarica a fermata (soluzione 2)

\begin{tabular}{|c|c|c|c|c|}
\hline \multirow{2}{*}{ Voce } & $\begin{array}{l}\text { Evasori } \\
(25 \%)\end{array}$ & \begin{tabular}{|c|} 
Con bi- \\
glietto \\
$(19 \%)$
\end{tabular} & $\begin{array}{c}\text { Abbonati } \\
\text { mensili } \\
(26 \%)\end{array}$ & $\begin{array}{c}\text { Abbonati } \\
\text { annuali } \\
(30 \%)\end{array}$ \\
\hline & $\begin{array}{c}\text { Costo } \\
\text { titolo } \\
\text { (€/cad.) }\end{array}$ & \begin{tabular}{|c|} 
Valori \\
giorna- \\
lieri $(\mathrm{n})$.
\end{tabular} & $\begin{array}{c}\text { Valori } \\
\text { annuali } \\
\text { (n.) }\end{array}$ & $\begin{array}{l}\text { Ricavi } \\
(€ / \text { anno) }\end{array}$ \\
\hline $\begin{array}{l}\text { Nuovi utenti da } \\
\text { strada }\end{array}$ & & 996 & & 233.419 \\
\hline $\begin{array}{l}\text { Evasori (senza bi- } \\
\text { glietto) }\end{array}$ & 0 & 249 & 90.885 & 0 \\
\hline Muniti di biglietto & 1,5 & 187 & 68.164 & 102.246 \\
\hline $\begin{array}{l}\text { Con abbona- } \\
\text { mento mensile } \\
\end{array}$ & 46 & 131 & 1.569 & 72160 \\
\hline $\begin{array}{l}\text { Con abbona- } \\
\text { mento annuale }\end{array}$ & 395 & 149 & 149 & 59.013 \\
\hline $\begin{array}{l}\text { Nuovi utenti gene- } \\
\text { rati }\end{array}$ & 1,5 & 150 & & 35.153 \\
\hline $\begin{array}{l}\text { Evasori (senza bi- } \\
\text { glietto) }\end{array}$ & 0 & 38 & 13.688 & 0 \\
\hline Muniti di biglietto & 1,5 & 28 & 10.266 & 15.398 \\
\hline $\begin{array}{l}\text { Con abbona- } \\
\text { mento mensile }\end{array}$ & 48 & 20 & 236 & 10.868 \\
\hline $\begin{array}{l}\text { Con abbona- } \\
\text { mento annuale }\end{array}$ & 395 & 23 & 23 & 8.888 \\
\hline $\begin{array}{l}\text { Utenti mezzo pub- } \\
\text { blico }\end{array}$ & & 16.725 & & 4.949 .764 \\
\hline $\begin{array}{l}\text { Evasori (senza bi- } \\
\text { glietto) }\end{array}$ & 0 & 4.181 & 1.526 .156 & 0 \\
\hline Muniti di biglietto & 1,5 & 5.018 & 1.831 .388 & 2.747 .081 \\
\hline $\begin{array}{l}\text { Con abbona- } \\
\text { mento mensile }\end{array}$ & 46 & 2.195 & 26.342 & 1.211.726 \\
\hline $\begin{array}{l}\text { Con abbona- } \\
\text { mento annuale }\end{array}$ & 395 & 2.509 & 2.509 & 990.956 \\
\hline
\end{tabular}

Tabella 6 - Valori residui previsti per la filoviaria con ricarica a fermata (soluzione 2)

\begin{tabular}{l|c|c|c|c}
\multicolumn{1}{c|}{ Voce } & Totale $(€)$ & $\begin{array}{c}\text { Vita } \\
\text { utile } \\
\text { n. anni) }\end{array}$ & $\begin{array}{c}\text { Anni } \\
\text { residui } \\
(\mathbf{n} .)\end{array}$ & $\begin{array}{c}\text { Valore } \\
\text { residuo } \\
(€)\end{array}$ \\
\hline Stazione ricarica & 5.050 .800 & 20 & 18 & 4.545 .720 \\
\hline Mezzi filotranviaria & 30.866 .000 & 20 & 18 & 27.779 .400 \\
\hline $\begin{array}{l}\text { Batterie mezzi di } \\
\text { trasporto }\end{array}$ & 3.355 .600 & 7 & 3 & 1.437 .857 \\
\hline $\begin{array}{l}\text { Linee trasporto col- } \\
\text { linari }\end{array}$ & & & & \\
\hline Mezzi linee 470-470/ & 1.128 .500 & 20 & 4 & 225.700 \\
\hline Mezzi linea 479 & 902.800 & 20 & 4 & 180.560 \\
\hline Mezzi linee 480-482 & 1.720 .200 & 20 & 9 & 774.090
\end{tabular}

\subsection{Il calcolo degli indicatori di sostenibilità economico-finanziaria}

Per ciascuna delle soluzioni considerate si è quindi sviluppato un modello di ACB secondo i due diversi approcci indicati dal Bando del MIT:

1) finanziario, ossia tenendo conto dei soli costi e ricavi pertinenti all'azienda trasportistica locale (AMT) che svilupperà l'investimento;

2) economico, ossia tenendo conto dei costi e dei benefici che derivano all'azienda AMT e alla collettività dalla nuova infrastruttura trasportistica (Fig. 5a e 5b).

Per ciascuna delle tre soluzioni considerate, i modelli ACB sono stati sviluppati in riferimento allo scenario 0 ("Business as Usual"); i valori di costo e di ricavo inseriti come input del modello sono quindi le differenze dei costi e dei ricavi tra lo scenario progettuale e quello 0 ("Business as Usual").

\subsection{Risultati}

I modelli di ACB sviluppati per le tre soluzioni evidenziano una non sostenibilità finanziaria per tutte e tre le soluzioni analizzate mentre - per contro - considerando anche gli effetti "esterni" generati (analisi economica) - tutte le soluzioni risultano sostenibili. Gli scostamenti dei valori degli indicatori tra queste due analisi sono notevoli, per l'elevato contributo dei benefici ambientali e sociali derivati (Tab. 7). Relativamente all'analisi finanziaria, tutti i VANF risultano negativi con una oscillazione tra i $-51,10$ milioni di euro per la soluzione 1 (con alimentazione da linea aerea) ed i -28,46 milioni di euro per la soluzione 2 (con ricarica a fermata); in accordo con i valori negativi del VANF, I'indicatore relativo al rapporto tra Benefici e Costi scontati $(\mathrm{B} / \mathrm{C})$ assume sempre valori inferiore all'unità. La differenza dei risultati ottenuti è essenzialmente attribuibile ai costi di investimento (ed in particolare nel numero di mezzi da acquistare) e, per la soluzione 1, nell'alto costo di realizzazione della linea aerea (circa 700 mila euro a chilometro). Per quanto riguarda invece i TIRF, questi presentano valori negativi per le soluzioni 1 e 2 (rispettivamente 10,03\% e - 3,61\%) mentre non esiste per la sola soluzione 3 in quanto la funzione del VANF è sempre negativa ${ }^{26}$.

Tutte e tre le soluzioni hanno un periodo di ritorno superiore alla vita utile dei mezzi di trasporto impiegati (20 anni).

L'analisi economica evidenzia una sostenibilità per tutte e tre le soluzioni: i VANE sono ampiamente positivi (oscillano tra i 173,22 milioni di euro della soluzione 3 e i 188,16 milioni di euro della soluzione 1) mentre i TIRE annui sono ampiamente positivi (oscillano tra il $31,94 \%$ della soluzione 1 e il $38,89 \%$ della soluzione 2 ).

${ }^{26}$ Per questo tipo di investimenti realizzati da società pubbliche di trasporto il TIR minimo accettabile può essere assunto pari al tasso di interesse pagato per il finanziamento delle opere e l'acquisto dei mezzi necessari. 
Tabella 7 - Risultati degli indicatori sostenibilità finanziaria ed economica ottenuti per le tre soluzioni progettuali

\begin{tabular}{|c|c|c|c|c|}
\hline \multicolumn{5}{|l|}{ ANALISI FINANZIARIA } \\
\hline Soluzione filoviaria & $\begin{array}{l}\text { VANF } \\
\text { (milioni } \\
\text { di } € \text { ) }\end{array}$ & $\begin{array}{c}\text { TIRF } \\
\text { annuo } \\
(\%)\end{array}$ & $\begin{array}{c}\text { Periodo } \\
\text { di } \\
\text { Ritorno } \\
\left(n^{\circ} \text { anni) }\right.\end{array}$ & $\mathrm{B} / \mathrm{C}$ \\
\hline $\begin{array}{l}1 \text { - Con alimentazione da } \\
\text { linea aerea }\end{array}$ & $-51,10$ & $-10,03$ & no & 0,36 \\
\hline 2 - Con ricarica a fermata & $-28,46$ & $-3,61$ & no & 0,56 \\
\hline $\begin{array}{l}3 \text { - Con ricarica a capoli- } \\
\text { nea }\end{array}$ & $-49,22$ & - & no & 0,34 \\
\hline \multicolumn{5}{|l|}{ ANALISI ECONOMICA } \\
\hline Soluzioni filoviaria & $\begin{array}{l}\text { VANE } \\
\text { (Milioni } \\
\text { di } € \text { ) }\end{array}$ & $\begin{array}{c}\text { TIRE } \\
\text { annuo } \\
(\%)\end{array}$ & $\begin{array}{c}\text { Periodo } \\
\text { di } \\
\text { Ritorno } \\
\text { (n. anni) }\end{array}$ & $\mathrm{B} / \mathrm{C}$ \\
\hline $\begin{array}{l}1 \text { - Con alimentazione da } \\
\text { linea aerea }\end{array}$ & 188,16 & 31,94 & 6 & 6,61 \\
\hline 2 - Con ricarica a fermata & 179,05 & 38,89 & 6 & 7,98 \\
\hline $\begin{array}{l}3 \text { - Con ricarica a capoli- } \\
\text { nea }\end{array}$ & 173,22 & 37,20 & 6 & 6,98 \\
\hline
\end{tabular}

Complessivamente, i benefici sociali che derivano dall'adozione di una filoviaria tra Brignole e Prato e lungo la Val Bisagno porta a benefici medi annui per la collettività di circa 12 milioni di euro: di questi circa il $60 \%$ derivano dal risparmio di tempo che hanno gli utenti che utilizzano tale infrastruttura nello spostamento tra i due capolinea mentre il rimanente $40 \%$ sono relativi a benefici derivanti dal minor inquinamento acustico e atmosferico, dai benefici climatici e dalla minor incidentalità degli utenti della strada. Ai fini di verificare quali sono le condizioni finanziarie che garantirebbero un equilibrio tra costi di investimento e benefici per l'investitore (AMT) è stato quindi calcolato l'ammontare minimo del contributo pubblico (fornito dal MIT) in conto capitale e a fondo perduto - necessario per ritornare dell'investimento. Nel modello di ACB tale contributo è stato considerato come disponibile in corrispondenza del primo anno e, quindi, va a ridurre i costi di investimento necessari per la realizzazione delle opere e l'acquisto dei mezzi; ai fini del calcolo è stato impostato che il periodo di ritorno dell'investimento sia pari alla vita utile dei mezzi (20 anni). I risultati riportati nella tabella 8 evidenziano che la soluzione con la ricarica a fermata richiederebbe un contributo pubblico a fondo perduto pari a 16,00 milioni di euro, minore rispetto alle altre due soluzioni $(23,20$ e 23,50 milioni di euro rispettivamente per la soluzione con alimentazione da linea aerea e con ricarica a capolinea).

Con tali contributi, i periodi di ritorno sono prossimi alla
Tabella 8 - Contributo economico a fondo perduto minimo per ciascuna soluzione progettuale

\begin{tabular}{l|c|c}
\hline Soluzione filoviaria & $\begin{array}{c}\text { Contributo a fondo } \\
\text { perduto } \\
\text { (milioni di } €)\end{array}$ & $\begin{array}{c}\text { Periodo di } \\
\text { Ritorno } \\
\left(\mathbf{n}^{\circ} \text { anni) }\right.\end{array}$ \\
\hline $\begin{array}{c}\text { - Con alimentazione da } \\
\text { linea aerea }\end{array}$ & 23,20 & 20 \\
\hline 2 - Con ricarica a fermata & 16,00 & 20 \\
\hline 3 - Con ricarica a capolinea & 23,50 & 20
\end{tabular}

vita utile dei mezzi utilizzati per ciascuna soluzione trasportistica analizzata.

\section{ANALISI DI SENSITIVITÀ E MONTE CARLO}

Ai fini di verificare l'influenza delle variabili di input sulla fattibilità economica della soluzione che presenta le migliori performance finanziarie (soluzione 2 - con ricarica a fermata) si è quindi sviluppata una analisi di sensitività. Le principali variabili (di costo e di ricavo) sono stati fatte variare (una alla volta) applicando ai valori iniziali di input una variazione percentuale (positiva e negativa fino ad un massimo del $\pm 20 \%$ ) e calcolate le corrispondenti variazioni (sempre percentuali) del VAN.

Il contributo a fondo perduto è stato invece considerato fisso nel suo ammontare minimo in quanto indispensabile affinché il VAN risulti prossimo allo zero.

La variabile che influenza maggiormente il valore del VANF è il costo di acquisizione dei mezzi, stimato in circa 33,6 milioni di euro; come si evince dalla Figura 7, un incremento del costo del $20 \%$ (44,4 milioni di euro) porta ad un VANF di -11,12 milioni di euro, valore che comprometterebbe la fattibilità finanziaria del progetto.

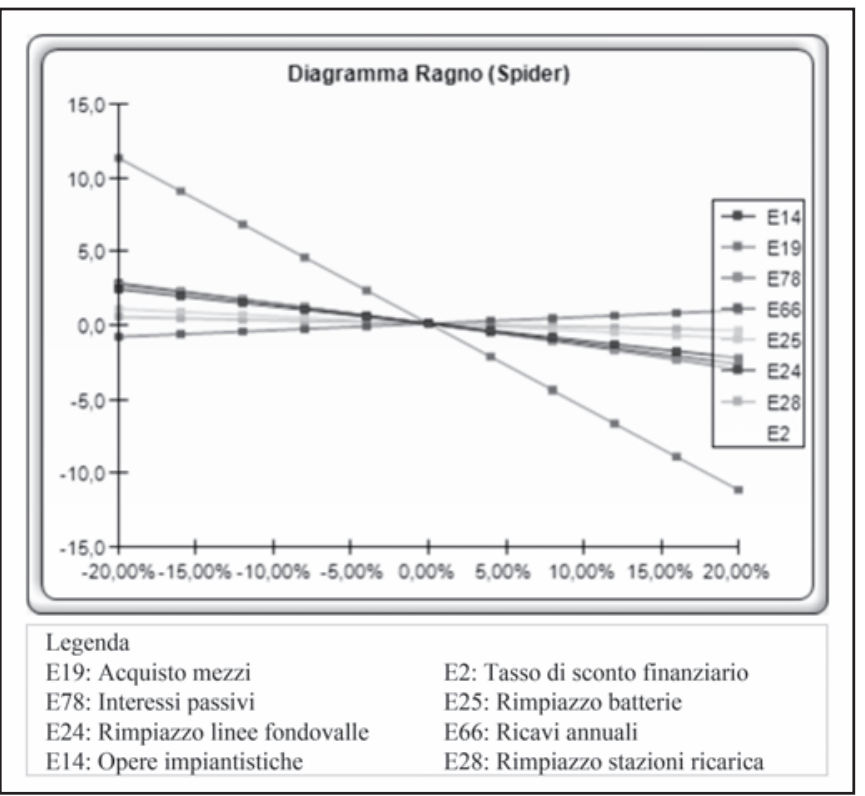

Figura 7 - Analisi di sensitività principali variabili di input. 


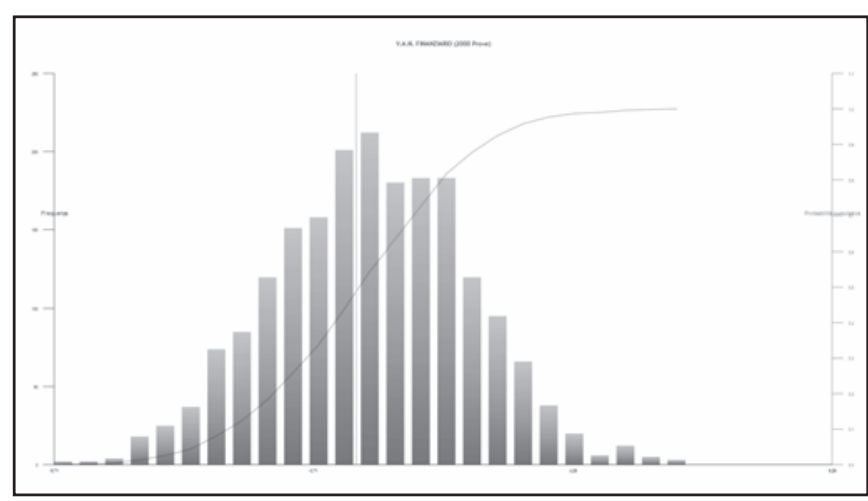

Figura 8 - Risultati dell'analisi Monte Carlo.

Meno sensibile il VANF rispetto alle altre variabili, anche se variazioni negative estreme portano a valori negativi dell'indicatore.

Secondo quanto stabilito dalle Linee Guida del MIT (MIT, 2014) è stata quindi sviluppata un'analisi del rischio ai fini di verificare l'attendibilità dei risultati ottenuti per il principale indicatore di sostenibilità finanziaria (VANF); a tal fine, sulle principali variabili di input, è stata applicata l'analisi di Monte Carlo. L'analisi si basa su di un algoritmo che genera una serie di numeri non correlati che seguono la distribuzione di probabilità ipotizzata per il fenomeno indagato (distribuzione normale); la correlazione tra i numeri è assicurata da un test chi quadrato ${ }^{27}$.

I risultati ottenuti dall'analisi di Monte Carlo evidenziano che c'è la probabilità del 49,55\% (Fig. 8) che il VANF finanziario sia inferiore al valore minimo impostato per la sostenibilità dell'investimento (pari a circa 110 milioni di , che si ottiene con il contributo pubblico di 16 milioni di euro); tale percentuale evidenzia che è necessario, per I'investitore, un maggior margine di contributo a fondo perduto che permetta di fronteggiare gli eventuali scenari negativi (contemporaneo aumento dei costi di realizzazione delle opere civili, delle opere impiantistiche, del prezzo di acquisto dei mezzi, diminuzione dei ricavi da bigliettazione, etc.) che potrebbero generare criticità finanziarie durante il periodo di gestione dell'infrastruttura trasportistica.

A tal fine si è quindi calcolato quale potrebbe essere il contributo che permetterebbe di ridurre il rischio al minimo; attraverso il modello di calcolo si è stimato che aumentando di soli 2 milioni di euro il contributo a fondo perduto, la probabilità che il VANF scenda al di sotto del valore minimo impostato è di solo l' $8,65 \%$. Con un contributo quindi di circa 18 milioni di euro (pari a circa il 16,3\% dell'investimento complessivo) I'investitore - relativamente ai soli costi della filoviaria - è quindi ampiamente

${ }^{27}$ Per ciascuna variabile di input si è impostata una possibile variazione massima del $\pm 20 \%$ (con singoli incrementi e decrementi del $\pm 5 \%$ ), mentre il numero massimo di simulazioni è pari a 5.000. garantito di poter fronteggiare anche eventuali scenari negativi e non solo ritorna dell'investimento prima della fine della vita utile dei mezzi (pari a 20 anni) ma riesce, almeno in parte, a finanziare una parte del costo per l'acquisto dei nuovi mezzi (circa 4).

\section{CONCLUSIONI}

Il presente contributo tratta dell'ACB come strumento a supporto delle decisioni di investimento in ambito trasportistico locale ai fini di valutare quale soluzione presenti il miglior rapporto tra benefici e costi e di quantificare il contributo economico pubblico necessario per la fattibilità economica dell'investimento da parte delI'azienda di trasporto locale (AMT).

Il caso studio in oggetto ha preso spunto dal Bando del MIT relativo al finanziamento di progetti trasportistici presentati dalle amministrazioni locali; in particolare si è fatto riferimento a tre possibili soluzioni filoviarie adottabili lungo la tratta Brignole-Prato (Val Bisagno) per le quali si è sviluppata una valutazione di fattibilità economica applicando la tecnica dell'ACB secondo i due approcci (finanziario e economico) indicati dalle Linee Guida del MIT (MIT, 2014).

Le conclusioni a cui gli autori sono giunti - e che vengono qui riepilogate brevemente - fanno riferimento a due ordini di considerazioni.

Il primo attiene maggiormente alle caratteristiche della tecnica valutativa impiegata; il secondo, propone una riflessione generale sull'impiego del metodo ACB nelle decisioni che riguardano gli investimenti pubblici di opere collettive in contesti urbani.

Circa il primo ordine, I'applicazione della tecnica evidenzia una serie di criticità: la prima è legata alla valutazione degli effetti esterni (collettivi) delle soluzioni e della loro quantificazione economica; alcuni aspetti e fattori che entrano nel conteggio (quali la salute o il tempo) non essendo oggetto di scambio commerciale, non hanno un valore (prezzo) esplicitamente indicato dal mercato e questo deve perciò essere determinato attraverso l'applicazione di metodologie indicate dalla letteratura (costo opportunità e disponibilità a pagare). I valori economici così quantificati non possono però essere raffrontati con i prezzi di mercato utilizzati per altre tipologie di costi e di benefici, in quanto risultano distorti da fattori esterni e soggettivi (Sullivan et al., 2006). Per questo motivo per i diversi prezzi di mercato si determina il corrispondente "prezzo ombra" attraverso l'applicazione di appositi coefficienti; tale operazione, però, è per sua natura complessa e può non riflettere in modo congruo i reali costi e benefici collettivi indotti.

Una seconda criticità è invece riconducibile alla complessità dei progetti trasportistici sottoposti a valutazione; essi fanno entrare in gioco decisioni e previsioni che interessano non solo l'asse trasportistico considerato ma anche altri a questo connesso; nel caso in oggetto si sono considerate alcune modifiche al servizio di trasporto relativo ai 
mezzi che collegano gli ambiti abitati collinari, con la variazione di alcuni percorsi e la soppressione di alcune linee. Ciò rende più complesso la definizione del quadro complessivo di costi e benefici da considerare nel modello di $\mathrm{ACB}$ e più incerti i risultati degli indicatori di sostenibilità economica-finanziaria.

Qui il metodo comincia a mostrare le prime incertezze, dovute proprio alla sua declinazione in questo specifico campo applicativo: è chiaro che il delinearsi della complessiva sostenibilità dell'opera dipende da "chi" sostiene il costo e "chi" ne ricava i benefici. È evidente che, anche se la pianificazione e la gestione dei progetti è demandata alla Pubblica Amministrazione (anche mediante il gestore del TPL), è la collettività che ne consente la realizzazione attraverso il pagamento delle tasse e che gode dei conseguenti benefici. Per tale ragione l'atteggiamento corretto risiederebbe nell'adottare il punto di vista di quest'ultima. Del resto, è noto che il metodo offre i maggiori vantaggi quando è applicato in ambito aziendalista, ove investitore e beneficiario coincidono: si perviene, in questo caso, ad elementi utili alla dirigenza che può prendere le sue decisioni e anche il punto di vista dell'analista è individuato univocamente. È nondimeno assodato che i benefici derivanti da un intervento ad ampio spettro non coinvolgono la collettività in maniera omogenea; le alterazioni relative alla distribuzione di costi e benefici sono riconducibili a due ambiti principali:

- a livello geografico, in base alla dimensione del progetto, gruppi differenti di persone possono beneficiare degli effetti dovuti allo stesso. Ad esempio, la costruzione dell'asse protetto in Val Bisagno coinvolgerà l'insieme delle persone che risiedono, si muovono o lavorano all'interno del bacino, ma l'investimento tuttavia, essendo finanziato a livello nazionale, concerne tutti i cittadini in senso allargato;

- a livello sociale, la distribuzione dei costi e dei benefici è nella maggior parte dei casi disomogenea. Nel complesso un'operazione che risulta estremamente vantag- giosa può arrecare danni ad una determinata fascia di popolazione: occorre precisare che tale aspetto non risulta influente nell'ambito dell'analisi finanziaria, in quando costi e benefici presuppongono un unico soggetto investitore (che semmai procede poi alla distinzione dei costi spettanti, come nel caso del MIT e dell'azienda locale di trasporto).

Un terzo elemento di criticità e la previsione dei valori di costo e beneficio futuri; I'intervallo temporale indicato dalle Linee Guida del MIT (25 anni) comporta la necessità di inserire fattori di adeguamento legati all'inflazione nel tempo, la cui previsione è assai critica in quanto legata alla congiuntura di una molteplicità di fattori economici. Inoltre, quello che emerge dall'esperienza applicativa è che non sempre esiste una soluzione che presenta, rispetto alle altre, i migliori indicatori di sostenibilità sia secondo l'approccio economico che finanziario. Questo comporta che la scelta della soluzione deve essere operata dall'investitore tenendo conto non solo dei benefici collettivi generati ma anche dalle condizioni finanziarie necessarie per la fattibilità; questo anche in relazione al fatto che, per i progetti di investimento che interessano il traporto pubblico, le entrate derivanti dal pagamento dei biglietti da parte degli utenti coprono solo una parte dei costi fissi e variabili del servizio, e che, quindi, si rende sempre necessario un consistente contributo economico pubblico. Non secondaria appare, infatti, la considerazione svolta in merito all'analisi di sensitività al rischio: se la finalità di partenza è la copertura del rischio anche nel caso di contingenze negative, è chiaro che il lievitare dei costi potrebbe influire di gran lunga sulla determinazione del vantaggio apportato dall'infrastruttura, ma sposterebbe il dibattito, dunque, sul ritorno dell'investimento come fattore prioritario e non più sull'utilità dell'opera (smentendo quindi le sue premesse). Si pensi, ad esempio, all'andamento del mercato energetico che risulta essere una variabile altamente connessa alI'investimento in questione: la sensitività potrebbe essere tale da negare la sostenibilità stessa dell'opera, nonostante,

Tabella 9 - Variazioni dei valori degli input e corrispondenti variazioni dell'output (VANF)

\begin{tabular}{|c|c|c|c|c|c|c|}
\hline \multirow[b]{2}{*}{ Variabile } & \multicolumn{3}{|c|}{ Valore di base VANF: $0,11 \mathrm{M} €$} & \multicolumn{3}{|c|}{ Cambiamenti dell'input } \\
\hline & $\begin{array}{l}\text { Svantaggio } \\
\text { dell'output }\end{array}$ & $\begin{array}{l}\text { Vantaggio } \\
\text { dell'output }\end{array}$ & $\begin{array}{l}\text { Intervallo } \\
\text { efficace }\end{array}$ & $\begin{array}{l}\text { Min. valore } \\
\text { input }\end{array}$ & $\begin{array}{c}\text { Max valore } \\
\text { input }\end{array}$ & $\begin{array}{c}\text { Valore base } \\
\text { input }\end{array}$ \\
\hline E19: Acquisto mezzi & 11,3413 & $-11,1239$ & 22,47 & $26.937 .600 €$ & $40.406 .400 €$ & $33.672 .000 €$ \\
\hline E78: Interessi passivi & 2,7137 & $-2,9954$ & 5,71 & $4 \%$ & $6 \%$ & $5 \%$ \\
\hline E24: Rimpiazzo linee fondovalle & 2,8553 & $-2,6379$ & 5,49 & $24.692 .800 €$ & $37.039 .200 €$ & $30.866 .000 €$ \\
\hline E14: Opere impiantistiche & 2,4447 & $-2,2274$ & 4,67 & $5.602 .240 €$ & $8.403 .360 €$ & $7.002 .800 €$ \\
\hline E2: Tasso di sconto finanziario & 2,5138 & $-1,9635$ & 4,48 & $3 \%$ & $5 \%$ & $4 \%$ \\
\hline E25: Rimpiazzo batterie & 1,1025 & $-0,8851$ & 1,99 & $5.368 .000 €$ & $8.052 .000 €$ & $6.710 .000 €$ \\
\hline E66: Ricavi annuali & $-0,7906$ & 1,0079 & 1,80 & $214.858 €$ & $322.287 €$ & $268.572 €$ \\
\hline E28: Rimpiazzo stazioni ricarica & 0,5581 & $-0,3408$ & 0,90 & $4.040 .640 €$ & $6.060 .960 €$ & $5.050 .800 €$ \\
\hline
\end{tabular}


a maggior ragione al fine della sostenibilità dei trasporti, ve ne sarebbe bisogno.

E qui entriamo nel secondo ordine di considerazioni conclusive, che concerne maggiormente l'impiego del metodo ACB come tecnica indicata dal MIT per valutare come già menzionato - quale soluzione presenti il miglior rapporto tra benefici e costi e per la quantificazione del contributo economico pubblico che si rende necessario per la fattibilità economica dell'investimento.

Ciò che desta perplessità è che tale strumento sia proposto per l'assegnazione di fondi per l'ammodernamento del sistema trasportistico delle aree metropolitane (già in stato di allarme per criticità ambientali ripetute) in regime di competizione fra esse: ne deriva che, alla tecnica sia chiesto di dimostrare che, in ottica ministeriale, un intervento proposto massimizzi "meglio" I'investimento di un altro. Ma lo strumento $\mathrm{ACB}$, come ampiamente dimostrato in questo caso, non rileva grandi differenze in termini di sostenibilità finanziaria per le tre soluzioni, mentre il discosto dei risultati che si ottiene fra le due analisi (finanziaria ed economica) sono notevoli, proprio per l'elevato contributo dei benefici ambientali e sociali derivati dalle soluzioni trasportistiche, ovvero mettendo in campo una valutazione più omnicomprensiva del valore dell'opera. Proprio in ragione di queste criticità recenti applicazioni hanno sperimentato I'applicazione dell'ACB combinata con altre tecniche valutative (quali I'analisi multicriterio o l'analisi Costi efficacia) per tenere conto anche degli aspetti qualitativi delle soluzioni trasportistiche (Tudela, Akiki e Cisternas, 2006; Guhnemann, Laird e Pearman, 2012).

Dai risultati ottenuti nel presente studio appare chiaro come sia importante ricondurre questi elementi nella valutazione, ma essi non siano in realtà dirimenti dal punto di vista delI'ammontare complessivo che, nelle tre soluzioni, non varia poi molto. L'ACB si dimostra quindi adatto ed efficace nel calcolare il totale dell'investimento complessivo per la richiesta di contributo, ma non per l'analisi delle scelte trasportistiche che appaiono quasi sullo stesso piano.

Ciò su cui si vuole porre l'accento è che lo spazio attribuito alla scelta deve comporsi di un equilibrio tra gli effetti sociali indotti e la sostenibilità finanziaria dell'intervento.

Nell'ambito degli investimenti pubblici, per i quali uno dei principali scopi consiste nell'operare per ridurre le disuguaglianze economiche, attraverso il raggiungimento del benessere di gruppi svantaggiati, I'ACB potrebbe portare all'adozione di soluzioni generalistiche e che non mettono in luce l'aspetto discrezionale tra le alternative, in quanto non consapevolmente assunte come risposte possibili alle problematiche del contesto esaminato.

Tali riflessioni appaiono essere oggi di grandissima attualità all'indomani dell'attribuzione dei finanziamenti europei per i cosiddetti Recovery Plan nazionali, nell'ambito dei quali vengono assegnati fondi per la realizzazione di opere sul territorio considerate prioritari per il rilancio del Paese in epoca post-pandemica. È chiaro che se non si afferma una cultura più ampia nella valutazione dei "lavori pubblici" (secondo una dicitura magari obsoleta, ma aggregativa di molteplici aspetti, urbanistici, costruttivi, ambientali), le considerazioni che sostengono la fattibilità di questo o quest'altro intervento potranno risultare parziali o aprioristiche, perché non appaiono come esito di un adeguato "scandaglio" metodologico.

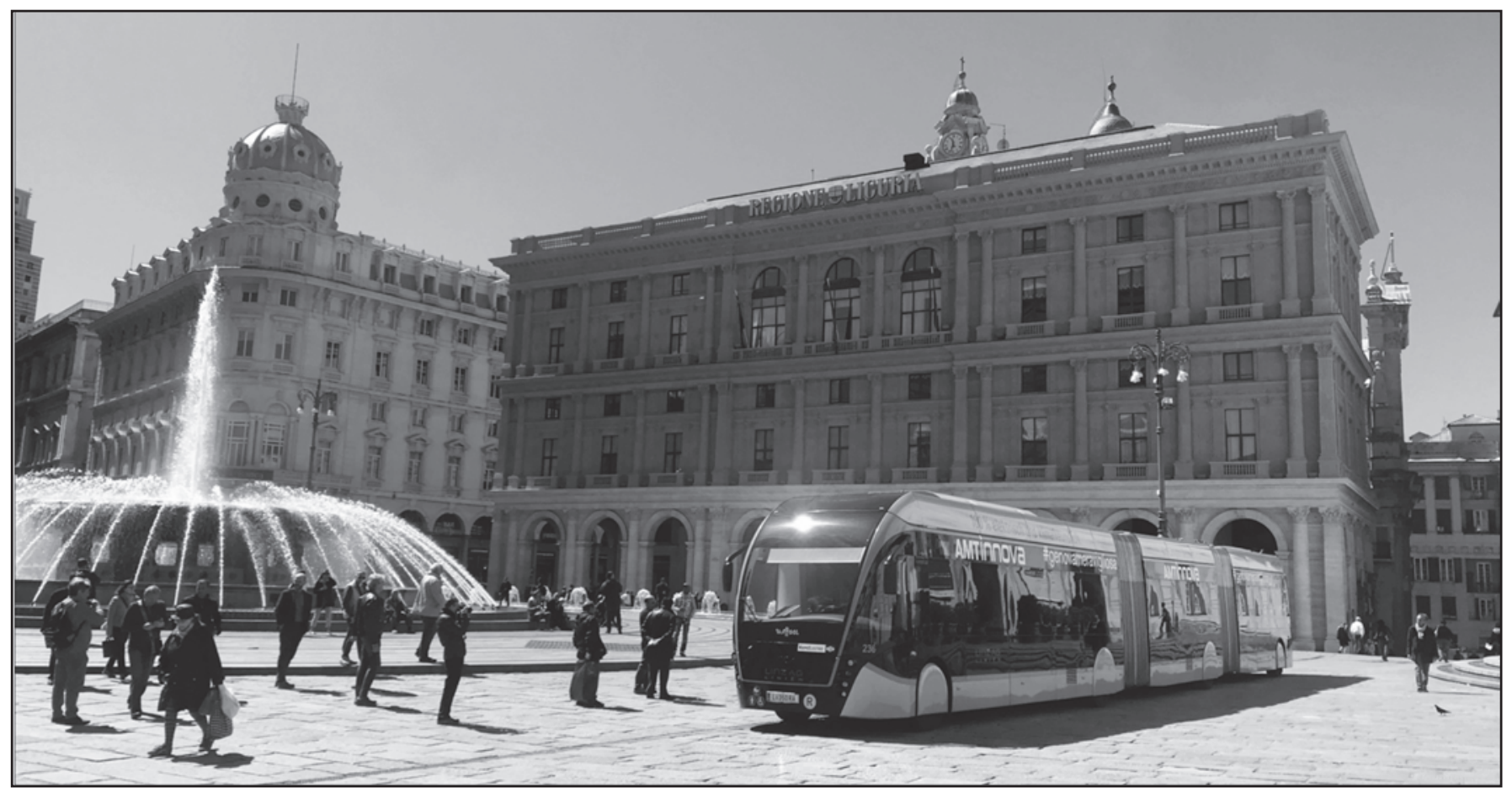

Figure 9 - Il filobus a tre casse (24 m.) durante il test effettuato a Genova il 6 maggio 2019. 
Note

Il presente lavoro è stato sviluppato nell'ambito della tesi di Laurea "Le trasformazioni della mobilità urbana" (candidati: Andrea Marcenaro e Giulio Minuto; relatori: professori Ilaria Delponte, Paolo Rosasco; correlatore: Ing. Riccardo Genova - Laurea Magistrale in Ingegneria Edile-Architettura, Università degli Studi di Genova - Scuola Politecnica). La responsabilità di quanto riportato nel presente lavoro è da ascriversi ai soli autori.

* Ilaria Delponte, Dipartimento Ingegneria Civile, Chimica e Ambientale (DICCA) - Scuola Politecnica - Università degli Studi di Genova e-mail: ilaria.delponte@unige.it

** Paolo Rosasco, Dipartimento Architettura e Design (DAD) - Scuola Politecnica - Università degli Studi di Genova e-mail: paolo.rosasco@unige.it

\section{Contributo degli autori}

Ilaria Delponte ha curato i paragrafi 1, 2 e 3; Paolo Rosasco ha curato i paragrafi 4, 5 e 6: Il paragrafo 7 è stato curato congiuntamente dagli autori.

\section{Bibliografia}

BANISTER D., The sustainable mobility paradigm, Transport Policy, Vol 15, No 2, 2008, pp. 73-80.

COMUNitÀ EUROPEA, Direttiva 2014/94/Ue del parlamento europeo e del consiglio del 22 ottobre 2014 sulla realizzazione di un'infrastruttura per i combustibili alternativi, 2014.

Città Metropolitana di Genova, Piano Urbano della Mobilità sostenibile della Città Metropolitana di Genova (PUMS), Città Metropolitana di Genova, 2019 (documento scaricabile all'indirizzo internet: https://pums.cittametro politana.genova.it/content/il-pums-di-genovametropoli).

COMUNE DI GENOVA, Piano Urbano della Mobilità genovese - Documento finale, Comune di Genova, 2010 (documento scaricabile all'indirizzo internet: http://ww w.mobilitypoint.it/Data/Sites/1/media/pdf/pum/pum.pdf.).

Comune di Genova, Annuario statistico - Edizione 2018, Comune di Genova, 2019.

COSTA Á., The organisation of urban public transport systems in Western European metropolitan areas. Transport Research Part A: Policy Practice, Vol. 30, No 5, 1996, pp. 349-359.

Delponte I., "Transport, Ict and the City. Why are Cities interested in Ict?", In Papa R. (a cura di), Towards Smart City. A scientific approach, 2014, pp.17-26.

DISNEY J., Competing through quality in transport services, Managing Service Quality: An International Journal, Vol. 8, No 2, 1998, pp. 112-118.

van Egmond P.W., NiJkamp P., Vindigni G., A comparative analysis of the performance of urban public transport systems in Europe. International Social Science Journal,
Vol. 55, No 176, 2003, pp. 235-247.

Energy and Strategy Group, E-mobility report, E-Book, 2018.

EUROPEAN HOUSE-AMBrosetTI, Il futuro della mobilità urbana - integrazione e nuovi modelli di gestione nel caso italiano, 2017.

European Comission, Guide to Cost-Benefit Analysis of Investment Projects, 2014.

Gal-Tzur A., Grant-Muller S.M., Kuflik T., Minkov E., Nocera S., SHOOR I., The potential of social media in delivering transport policy goals. Transport Policy, Vol. 32, 2014, pp. 115-123.

GibBons S., LyytikäInen T., Overman H.G., SANChis-Guarner R., New road infrastructure: The effects on firms, Journal of Urban Economics, Vol. 110, 2019, pp. 35-50.

Godinho P., 1 Joana Dias J., Cost-Benefit Analysis and the Optimal Timing of Road Infrastructures, Journal of Infrastructure Systems, December, 2012.

Gonzalez-Feliu J., Costs and benefits of railway urban logistics: a prospective social cost benefit analysis, https//halshs.archives-ouvertes.fr/halshs-01056135.

Guhnemann A., Laird J.J., Pearman A.D., Combining costbenefit and multi-criteria analysis to prioritise a national road infrastructure programme, Transport Policy, Volume 23, pp. 15-24, September 2012.

GWiLliam K.M., Cities on the move: a World Bank urban transport strategy review, World Bank Publications, Washington DC, 2002.

HARFORD J.D., Congestion, pollution, and benefit-to-cost ratios of US public transit systems, Transportation Research Part D, Vol. 11, 2006, pp. 45-58.

HaRRIS I., WANG Y., WaNG H., ICT in multimodal transport 
and technological trends: Unleashing potential for the future, International Journal of Production Economics, Vol. 159, 2015, pp. 88-103.

HAJDUK S., The smartness profile of selected European cities in urban management - A comparison analysis, Journal of Business Economics and Management, Vol. 19, No 6, 2018, pp. 797-812.

HolmGren J., The efficiency of public transport operationsAn evaluation using stochastic frontier analysis, Research in Transportation Economics, Vol. 39, No 1, 2013, pp. 50-57. HyARD A., Cost-benefit analysis according to Sen: An application in the evaluation of transport infrastructures in France, Transportation Research Part A, Policy And Practice, Vol. 46, No 4, 2012, pp. 707-719.

INFRAS, External costs of transport - Updated study - Final report, University of Karlsruhe, 2004.

ISPRA, Qualità dell'ambiente urbano. Focus su mobilità pedonale in città, 2017 (documento scaricabile all'indirizzo internet: https://www.isprambiente.gov.it/it /pubblicazioni/stato-dellambiente/qualita-dellambienteurbano-xiii-rapporto.-focus-su-mobilita-pedonale-incitta.

MAleCKI E. J., Veldhoen M. E. Network activities, information and competitiveness in small firms. Geografiska Annaler: Series B, Human Geography, Vol. 75, No 3, 1993, pp. 131-147.

MCleod S., Scheurer, J., CurTis C., Urban public transport: planning principles and emerging practice, Journal of Planning Literature, Vol. 32, No 3, 2017, pp. 223-239.

Margorínová M., Trojanová M., Cost Benefit Analysis: Bypass of Prešov city, MATEC Web of Conferences 117, 00116, DOI: 10.1051/matecconf/20171170011 XXVI R-S-P Seminar, theoretical foundation of civil engineering, 2017. Ministero Infrastrutture e Trasporti (MIt)a, Decreto 4 agosto 2017 - Individuazione delle linee guida per i piani urbani di mobilità sostenibile, ai sensi dell'articolo 3, comma 7, del DIgs del 16 dicembre 2016 n. 257.

Ministero Infrastrutture E Trasporti (Mit)b, Linee Guida per la valutazione degli investimenti in opere pubbliche nei settori di competenza del Ministero delle Infrastrutture e dei Trasporti, 2017 (documento scaricabile all'indirizzo internet: https://www.mit.gov.it/normativa /decreto-ministeriale-numero-300-del-16062017.
Ministero Infrastrutture E Trasporti (Mit), Piano Nazionale Infrastrutturale per la Ricarica dei veicoli alimentati ad Energia elettrica, 2012.

Ministero Dello Sviluppo Economico (MISE), Piano Nazionale Integrato per I'Energia e Clima 2030, 2020.

Mugion R. G., Toni, M., Raharjo, H., Di Pietro, L., \& Sebathu, S. P., Does the service quality of urban public transport enhance sustainable mobility? Journal of Cleaner Production, Vol. 174, 2018, pp. 1566-1587.

Nutı F., L'analisi costi-benefici, Società Editrice il Mulino, Bologna, 2017.

Pflieger G., Kaufmann V., Pattaroni L., Jemelin C., How does urban public transport change cities? Correlations between past and present transport and urban planning policies, Urban Studies, Vol. 46, No 7, 2009, pp. 1421-1437. RoY W., YVRANDE-BILlon A., Ownership, contractual practices and technical efficiency: The case of urban public transport in France, Journal of Transport Economics and Policy, 2007, Vol. 41, No 2, 2007, pp. 257-282.

Schwanen T., Lucas K., Akyelken N., Solsona D. C., Carrasco J. A., Neutens T., Rethinking the links between social exclusion and transport disadvantage through the lens of social capital, Transportation Research Part A: Policy and Practice, Vol. 74, 2015, pp. 123-135.

SHEFER D., HAVIRAM H., Incorporating agglomeration economies in transport cost-benefit analysis: The case of the proposed light-rail transit in the Tel-Aviv metropolitan area, Regional science, 2005.

Standing C., Standing S., BiermanN, S., The implications of the sharing economy for transport, Transport Reviews, Vol. 39, No 2, 2019, pp. 226-242.

Sullivan W.G., Wicks E.M., LuxhO J.T., Economia applicata all'ingegneria, Pearson Education Italia, 2006.

Tudela A., Akiki N., Cisternas R., Comparing the output of cost benefit and multi-criteria analysis an application to urban transport investments, Transportation Research Part A, Vol. 40, 2006, pp. 414-423.

\section{Internet references}

Automobile Club d'Italia, www.aci.it

Istituto Nazionale di Statistica (ISTAT), www.istat.it. Ministero Infrastrutture e Trasporti, www.mit.gov.it 
